\title{
Estudo Hidrogeológico de Terreno Cristalino com Manto de Intemperismo - Área Piloto de Atibaia (SP)
}

Itabaraci Nazareno Cavalcante

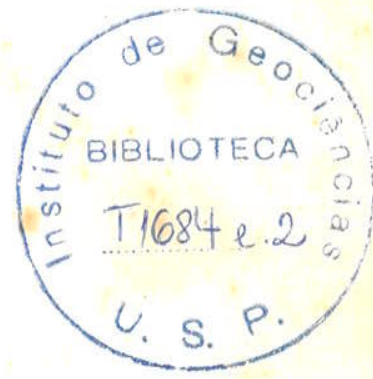
Orientador: Prof. Dr. Aldo da Cunha Rebouças

\section{COMISSÃO EXAMINADORA}

nome

Presidente:

Examinadores: as8.

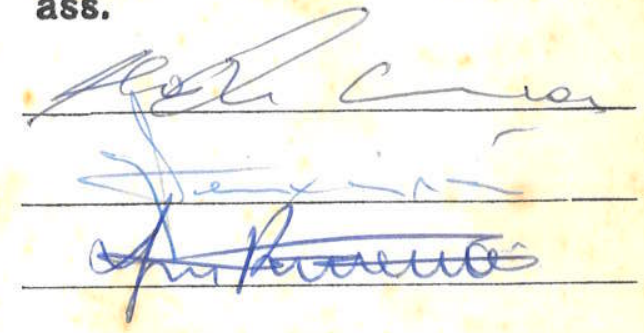

São Paulo 
UNIVERSIDADE DE SÃO PAULO

INSTITUTO DE GEOCIENCIAS

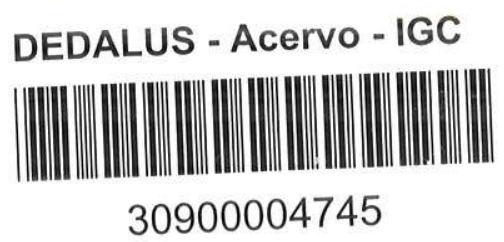

ESTUDO HIDROGEOLÓGICO DE TERRENO CRISTALINO COM MANTO DE INTEMPERISMO

- ÁREA PILOTO DE ATIBAIA (SP)

Itabaraci Nazareno Cavalcante

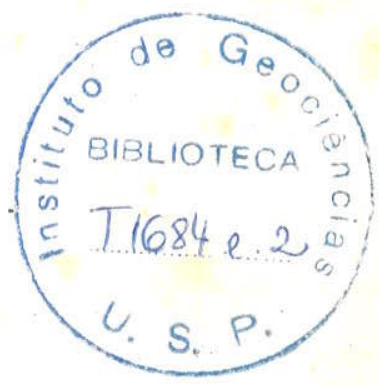

ORIENTADOR : Prof. Dr. Aldo da Cunha Rebouças

\section{DISSERTACÃO DE MUESTRADO}

Área cie Concentração : Recursos Minerais e Hidrogeôlogia

São Paulo

- $1990-$ 


\section{SURARTIO}

\section{LISTA DE FIGURAS}

LISTA DE TABELAS

LISTA DE QUADROS

LISTA DE FO'TOS

\section{ABGTRACT}

RESUMO

DEDICATÓRIA

AGRADECIMENTOS

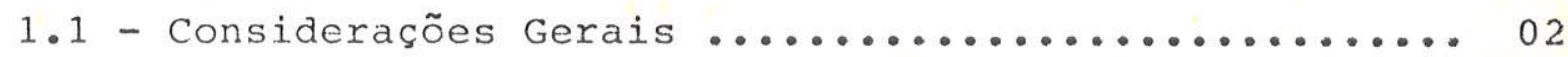

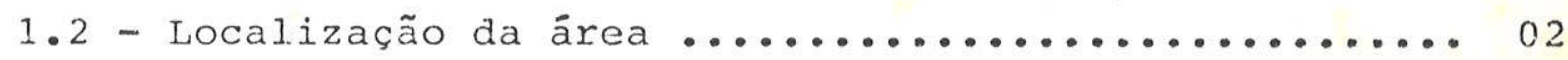

1.3 - objetivos ............................ 04

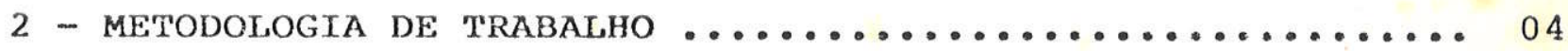

2.1 - Pesquisa Bibliográfica ..................... 04

2.2 - Interpretação Fotogeológica e Geologia de Campo ... 05

2.3 - Cadastro de Pontos d'Agua .................... 07

2.4 - Análises Químicas das Åguas Subterxâneas ........ 08

2.5 - Implantação de Piezômetros Muitiniveis .......... 09

3 - INTERDPETACXO DCS DADOS .......................... 17

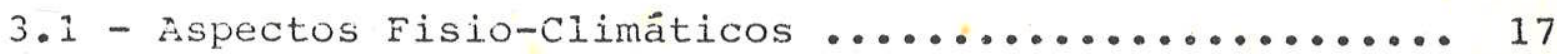

3.2 - Contexto Geológico ......................... 20

3.2.1 - Complexo Amparo ...................... 20

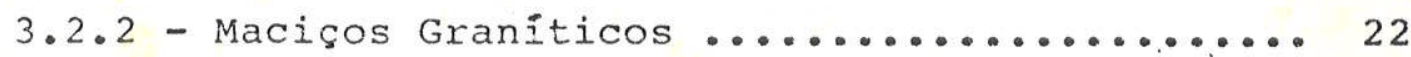

3.2 .3 - Coberturas Coluvionares................ 24

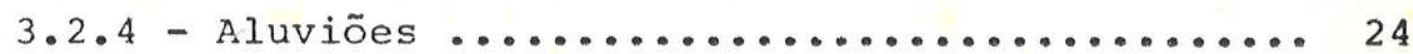

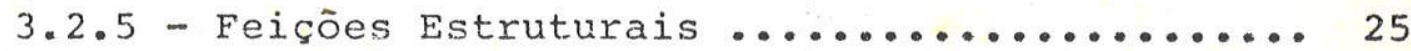




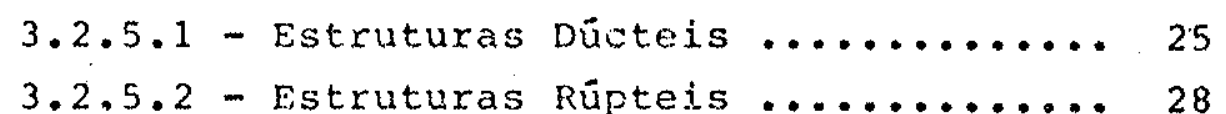

3.3 - Hidrologia de superficie .................. 32

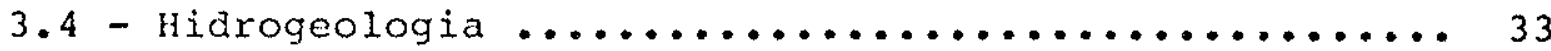

3.4.1 - Caracterização das Zonas Aquiferas ...... 36

3.4 .1 .1 - Manto de Intemperismo ........ 36

3.4 .1 .2 - Meio Fraturado ............. 46

3.5 - Estimativa das Reservas Hídricas Subterrâneas .... 55

3.5.1 - Reservas Renoväveis ................ 57

3.5 .2 - Reservas Permanentes ................ 57

3.6 - Hidroquimica ........................... 59

3.6.1 - Composição e Classificação das Aguas subterrâneas ..................... 59

3.6 .2 - Evolução da Composiç̃̃o Química .......... 64

3.6 .3 - Uso das Aguas ......................... 75

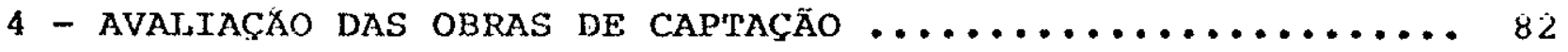

4.1 - Estado Atual da Tecnologia no setor ............ 82

4.2 - Considerações e Recomendações ................. 97

5 - PROPOSICAO DE METODOLOGIA DE ESTUDO .............. 106

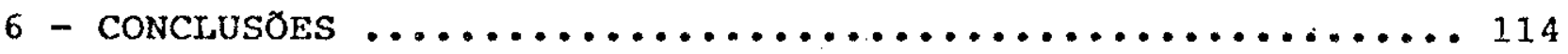

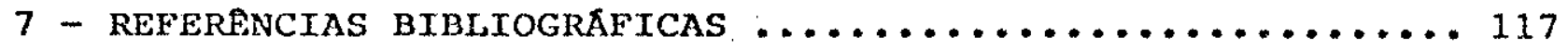


ANEXOS

01 - Caracteristicas dos pocos tubulares da região de Atibaia - sP

02 - Caracteristicas dos pocos escavados da região de Atibaia - SP

03 - Base Geológica e de Pontos d'Ägua 


\section{LISTA DE FIGURAS}

01 - Mapa de localização da área de estudo

02 - Piezômetro multinivel Ne 1. Local: Associação

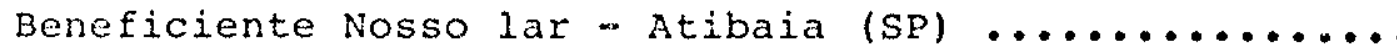

03 - Piezômetro multinivel Ne 2. Local: Sitio Dall'Anese -

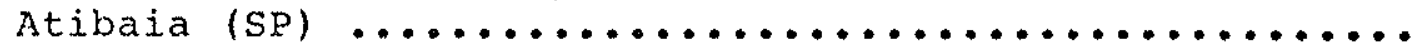

04 - Piezômetro multinivel Ne 3. Local: Sitio Santinha -

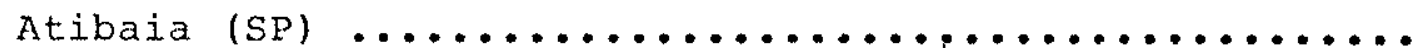

05 - Diagramas de frequencia dos polos dos eixos das dobras Fn +1 (Proj. Hem. Inf.) (MORALES et al, 1985) .......

06 - Diagrama de frequencia dos polos dos eixos das dobras da foliação principal, área total (Proj. Hem.

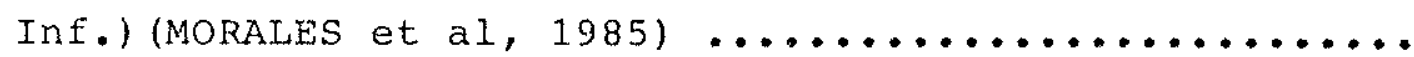

07 - Diagrama de roseta das direções de fraturas - Atibaia (SP)

08 - Diagrama de frequência dos polos das atitudes de

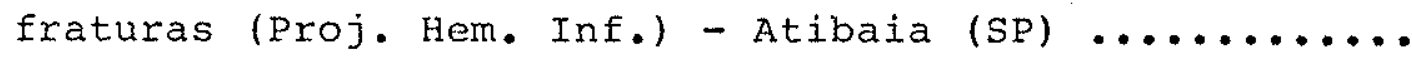

09 - Diagrama de frequência dos polos das atitudes de fraturas (Proj. Hem. Inf.) - Atibaia (SP): a)

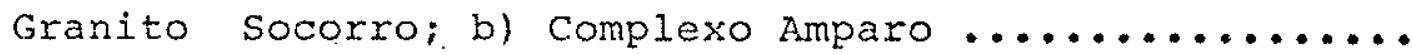

10 - Localização da área estudada em relação as sub-bacias

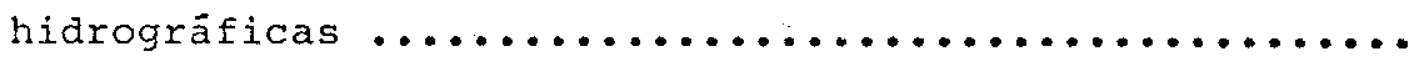

11 - Potenciais de ăguas subterrāneas no Brasil (REBOUÇAS,

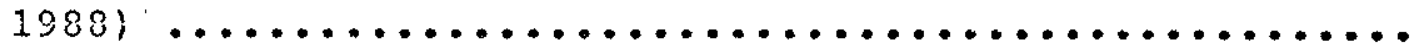

12 - Distribuição de frequência das espessuras do manto de alteração 
13 - Distribuição de frequência das espessuras saturadas ...

14 - Distribuição de frequência dos niveis d'água dos pocos: a) Tubulares; b) Escavados ......................

15 - Distribuição de frequência das vazões dos poços

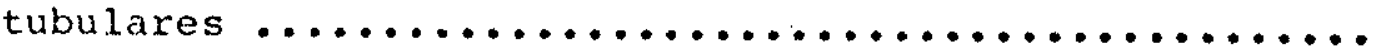

16 - Relação entre vazão e profundidade dos poços tubulares

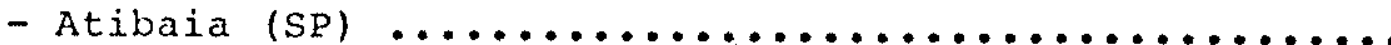

17 - Frequência das profundidades das entradas d'ägua na região de atibaia $(S P) \quad \ldots \ldots \ldots \ldots \ldots \ldots \ldots \ldots \ldots \ldots \ldots \ldots$

18 - Relação entre altitude da região e entradas d'ägua -

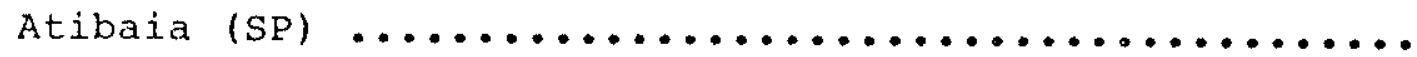

19 - Probabilidade logaritimo normal da capacidade especifica dos poços tubulares a região de Atibaia (SP)

20 - Relação entre vazão do poço e altitude local - Região

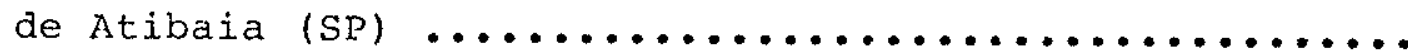

21 - Distribuição de frequência das medidas de condutividade elétrica especifica "in situ" das āguas subterrâneas: a) Poços tubulares; b) Poços escavados ...............

22 - Distribuição de frequência das medidas de pH "in situ" das âguas subterrãneas: a) Poços tubulares; b) Poços

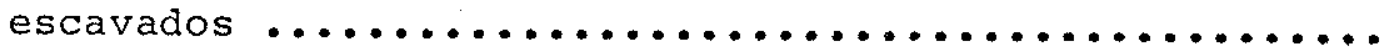

23 - Diagrama triangular das águas subterrâneas da região de Atibaia (SP)

24 - Fatores que influem na evolução química das äguas subterxāneas (cruz, 1985) ...................... 
25 - Diagrama de estabilidade do sistema CaO, $\mathrm{Al}_{2} \mathrm{O}_{3}, \mathrm{SiO}_{2}$,

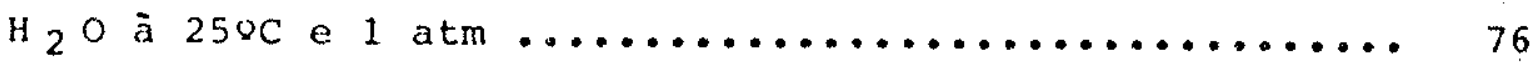

26 - Distribujcão de frequência das profundidades dos pocos escavados - Atibaia (SP) ...................... 84

27 - Distribuicão de frequência das alturas das colunas d'ägua dos poços escavados - Atibaia (SP) ........... 84

28 - Evolução temporal da perfuração de pocos tubulares na região ................................ 86

29 - Distribuição de frequéncia das profundidades dos poços

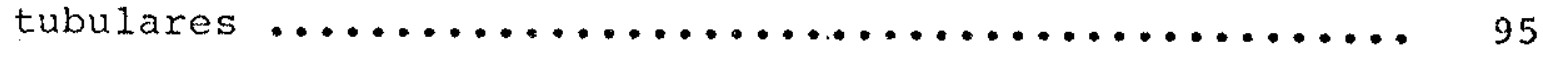

30 - Situacões encontradas na perfuracão de um poço no contexto cristalino (DUARTE, 1985) ................ 109 


\section{LISTA DE TABELAS}

01 - Medidas do nivel estático dos piezômetros multiniveis e pocos tubulares monitorados - Atibaia (SP) .........

02 - Caracteristicas dos pocos tubulares monitorados e dos piezômetros multinniveis ....................

03 - Anālises fisico-químicas (elementos maiores e $\mathrm{CO}_{2}$ Livre) - Atibaia (sp) ........................

04 - Análises quimicas de silício e elementos - traço das

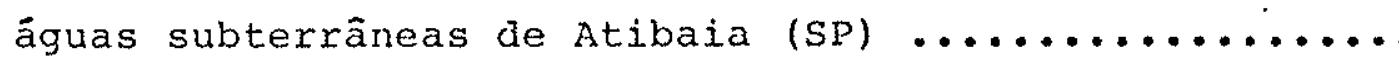

05 - Análises químicas de rochas da região de Atibaia (SP) - Oxidos e elementos menores (extraída de Morales et

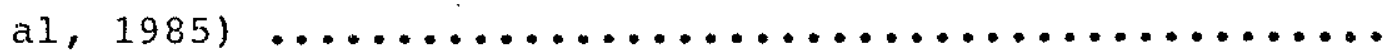

06 - Série de estapilidade dos minerais primários formadores de rochas, determinada por GOLDICH, 1938 (MELIL, 1975).

07 - Valores utilizados no diagrama de estabilidade do sistema $\mathrm{CaO}, \mathrm{Al}_{2} \mathrm{O}_{3}, \mathrm{SiO}_{2}$ e $\mathrm{H}_{2} \mathrm{O}$ a 258 e 1 atm......

08 - Situação atual dos poços tubulares - Atibaia (SP) ....

09 - Utilização das äguas subterrâneas na região de Atibaia (SP) ............................

10 - Firmas de perfuração de poços tubulares na região de Atibaia (SP)

11 - Métodos de perfuração de poros tubulares utilizados na

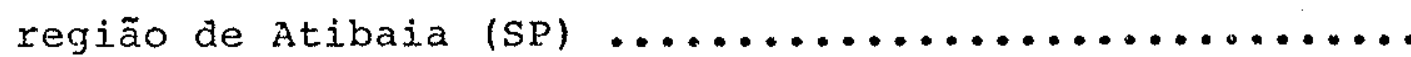

12 - Nümero de diâmetros utilizados na perfuração de poços

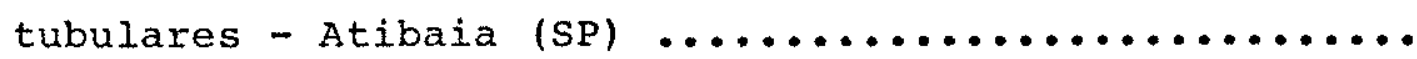


13 - Diâmetros utilizados na perfurąão de poços tubulares na região de Atibaia (SP)

14 - Diâmetros de revestimento dos poços tubulares - Atibaia (SP) 
LISTA DE QUADROS

01 - Médias multi-anuais do balanco hídrico ............ 35

02 - Caracteristicas dos agrotóxicos utilizados na região de

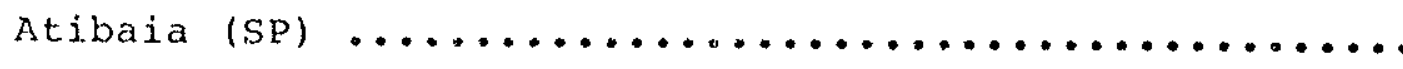




\section{LISTA DE FOTOS}

Foro 01 - Perfuracão com sonda rotativa, Modelo Ss-21 SONDEQ. Observa-se também, um poco tubular sem a laje de protecão. Local: Associação Beneficiente Nosso Lar - Atibaia (SP) $\ldots \ldots \ldots \ldots \ldots \ldots \ldots \ldots \ldots \ldots$

Foro 02 - Colocạ̃ão do piezômetro multinível. Local: Sitio Santinha - Atibaia (SP)

FoTo 03 - Tubo externo de PVC (6") e tampa de proteça do piezômetro multinível. Local: Sïtio Dall'Anese -

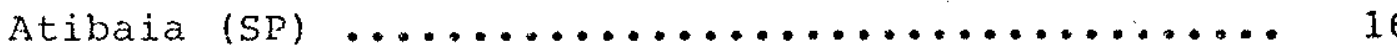

Foto 04 - Perfil de alteração do Complexo Amparo lespessura média de $20 \mathrm{~m}$ ) . Local: Rodovia Fernão Dias (BR381), trecho Atibaia - Bragança Paulista (SP) ....

FOTO 05 - Poço tubular abandonado, sem nenhum sistema de proteção, com profundidade de 180 metros e vazão de $0,3 \mathrm{~m}^{3} / \mathrm{h}$. Local: loteamento Santa Maria -

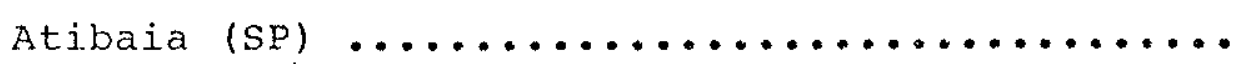


ABSTRACT

This paper resulted from hydrogeological investigation developed on crystalline terrain with weathering cover in the Atibaia area, southeastern säo paujo state. The goal was to determine occurrence conditions of ground-water, to evaluate captation worles, and to propose a method of study for that hydrogeological enviroment.

The work started by bibliographic research, followed by photointerpretation and field geology. A catalog of 79 tubulax wells, 157 excavated wells, and 12 springs was organized, including measurements of $\mathrm{pH}$, electric conductivity and static levels. Water samples were collected in 19 sources and had their physical - chemical quality analised. Also three mutilevel. piezometers were implanted.

The region is mainly composed by the Amparo Gneissic Migmatic Complex $(55,5 \%)$, and by the granites of Socorro (23 8 ) and Atibaia $(9 \%)$, alluvium $(7,8 \%)$ and colluvium. Three folding phases are present $(F n+1, F n+2$ and $F n+3)$, showing synforms and antiforms. Fraturing is intensive, with the Extrema Fault cutting the area along SW-NE.

Two aquifer zones were defined: regolith and fractured rock. The first covers the rock with thicknesses ranging from 20 to $40 \mathrm{~m}$ and reaching a maximum of $60 \mathrm{~m}$. Static levels in dug wells vary from 0,4 to $9 \mathrm{~m}$, and yelas average $0,9 \mathrm{~m}^{3} / \mathrm{h}$, with specific capacity of $0,225\left(\mathrm{~m}^{3} / \mathrm{h}\right) / \mathrm{m}$.

Tubular wells show yelds dominantly under io $\mathrm{m}=\mathrm{in}$ $(908)$, with average specific capacity of $6 \times 10^{-2}\left(\mathrm{~m}^{3} / \mathrm{h}\right) \mathrm{m}$.

Waters from dug wells are calcic bicarbonatic, but in tubular wells are mixed, sodic or calcic. 
In general there have not been technical criteria for location, drilling, and completion of wells. There is negligency with abandoned or desactivated captations, posing a potential risk of pollution of ground-water. 


\section{RESUMO}

Este trabalho mostra a pesquisa hidrogeológica desenvolvida em terreno cristalino com manto de intemperismo, na área piloto de Atibaia a sudeste do Estado de são paulo, tendo por objetivo caracterizar as condicões de ocorrência das águas subterrâneas, avaliar as obras de captacão e propor metodologia de estudo hidrogeolögico para este meio.

A metodologia de trabalho constou, basicamente, da pesquisa bibliográfica, interpretação fotogeológica e geologia de campo com cadastro de 79 poços tubulares, 157 pocos escavados e 12 fontes, com medidas de $\mathrm{pH}$, condutividade elétrica, nivel. estático, coleta de 19 amostras d'âgua para análises físicom quimicas e implantação de três piezômetros multiníveis.

A região é composta predominantemente pelo complexo Gnaissico-Migmatitico de Amparo $(55,5 \%)$, macicos graniticos de Socorro $(23 \%)$ e Atibaia $(9 \%)$, aluviões $(7,8 \%)$ coberturas coluvionares $(3,9 \%)$. Possui trés fases de dobramentos $(\mathrm{Fn}+1$, $\mathrm{Fn}+2$ e $\mathrm{Fn}+3)$ com sinformes e antiformes, e é bastante fraturada, com a principal falha seccionando a área de sw para $\mathrm{NE}$, constituindo o prolongamento da falha de Extrema.

Foram definidas duas zonas aquiferas: manto de intemperismo e meio fraturado. O manto de intemperismo recobre a área, com espessuras predominando no intervalo de $20-40 \mathrm{~m}$, alcançando até 60 metros. O nivel estático das cacimbas é de 0,4 a 9,0 metros (81 \%), vazão média de $0,9 \mathrm{~m}^{3} / \mathrm{h}$ e capacidade especifica de $0.225\left(\mathrm{~m}^{3} / \mathrm{h}\right) / \mathrm{m}$.

Os poços tubulares possuem vazão predominantemente abaixo de $10 \mathrm{~m}^{3} / \mathrm{h}(90 \%)$ e a capacicade especifica média é de $6 \times 30^{-2} \cdot\left(\mathrm{m}^{3} / \mathrm{h}\right) / \mathrm{m}$. 
As águas dos pocos escavados são bicarbonatadas câlcicas e as dos tubulares são mistas, passando para söaicas e cálcicas.

No geral não existe critéxio técnico para locação, perfuração e completacão dos poços. A não aplicacão das normas é visivel em quase todos os casos, existindo negligência quanto aos pocos desativados e abandonados, causando um risco potencial de poluição às āguas subterrāneas. 
Aos meus pais Gerson e Dolores, por todo carinho e ensinamento de vida.

A minha esposa zilar (Benice) que sempre me acompanhou com sua ternura e compreensão. 


\section{AGRADECIMENTOS}

A realização deste trabalho não seria possivel sem o auxilio inestimāvel de pessoas e entidades, às quais o autor gostaria de expressar sua sincera gratidão.

Ao Prof. Dr. Aldo da Cunha Reboucas, Diretor do Centro de Pesquisas de Aguas subterrâneas - CEPAs/IGUSP, pela orientação e amizade em todos os momentos do curso, além do constante incentivo ao desenvolvimento aa pesquisa.

Aos Professores Dr. Uriel Duarte, Dr. José Milton Benetti Mendes e Dr. Alberto Pacheco do Departamento de Geologia Econômica e Geofísica Aplicada/IGUSP, pelo apoio e disposição para discussões pertinentes ao tema abordado na Dissertação.

Aos Pós-Graduandos do Departamento de Geologia Econômica e Geofisjca Aplicada/IGUSP, Teodoro Isnard de Almeida, Sueli Yoshinaga, Maxia Amélia de S. Menezes, Mara A. Iritani, João Raimundo de Araújo e Seiju Hassuda, pela amizade e solidariedade em todas as etapas do curso.

Aos amigos Antônio Camargo, Lourdes e walter C. Leite do CEPAS/USP, que sempre foram de uma presteza inestimāvel durante o curso e no decorrer de todo o trabalho desenvolvido.

Em particular, ao Sr. Antônio Alves da silva, técnico especializado do CEPAS/USP, que acompanhou-me com sua experiência durante todas as fases de campo, inúmeras vezes tendo que abdicar da companhia de seus familiares para ir ao campo.

Ao Departamento de Geologia Econômica e Geofísica Aplicada por permitir a utilização da infra-estrutura departamental. 
A Universidade Federal do Ceará, especialmente ao Departamento de Geologia, por tex permitido meu afastamento para cursar a pós-Graduação.

A todos os colegas e amigos professores do Departamento de Geologia/UFC, nas pessoas dos Professores Ariston Cajaty, José Márcio Lins Marinho, Eva Batista Caldas, Joaquim Raul F. Torquato e Luiz Bianchi, pelo apoio e disposicão para discussöes concernentes a assuntos especificos do tema abordado na Dissertação.

A Profa. Dra. Marlúcia F. Santiago, pelo apoio e incentivo durante a fase de redação da Dissertação e pelo precioso tempo concedido as discussões, especialmente ao capitulo de hidroquimica.

Ao Sr. Geraldo Fiqueiredo, Da. Neide Figueiredo e ramilia, que carinhosamente souberam conviver comigo durante o tempo integral àe minha permanência em são Paulo.

A todos os amigos que nas horas de saudade sempre estiveram ao meu lado, especialmente wanda Almeiaa da Silva, Vânia Almeida da Silva e Talma, amigas que nunca se cansaram de incentivar-me ao término deste trabalho.

Ao estagiário Reyinalảo Antûnio berlolo - rGusp, pelá ajuda no âmbito de geologia estrutural aplicada à hidrogeologia e à pesquisa bibliogräfica.

Ao digitador e operador Francisco cleiton de sousa, pelo dedicado auxilio na digitação e organização do texto final.

As empresas particulares de perfuraça de poços que atuam na reqião (Jundsondas, Saiáqua e supersondas) que permitiram a utilizacão de seus arquivos, sem os quais o trabalho seria, certamente, muito mais prolongado. 
Aos diversos órgäos e entidades que contribuiram atravës de infra-estrutura e financiamento para o desenvolvimento deste trabalho, como o Centro de pesquisas de Aguas subterraneas - CEPAS/USP, Financiadora de Estudos e Projetos - FINEP e ao Conselho Nacional de Desenvolvimento Cientifico e Tecrológico CNPq.

Finalmente, agradeço a todos aqueles que direta ou indiretamente contribuiram para a realizaçäo deste trabalho. 


\section{1 - INTroduçスo}

Com o crescente aumento populacional e industrial, a demanda de recursos hïaricos tornou-se cada vez maior e as águas subterrâneas ganharam destaque em virtude das caracteristicas qualitativas e da localização em relação a demanda, minimizando os custos com tratamento e aducão.

Apesar de grande parte do Estado de são Paulo estar situado sobre a Bacia do Paraná, cuja vocação hidrogeológica permite obter-se vazões de atê $1.000 \mathrm{~m}^{3} / \mathrm{h} /$ poço, a $5 a$. Região Administrativa - CAMPINAS estä totalmente inserida sobre o contexto cristalino com manto de intemperismo, onde as vazões oscilam de 5 a $20 \mathrm{~m}^{3} / \mathrm{h}$, em média.

A pesquisa hidrogeológica torna-se imprescindivel e, na medida em que ela é desenvolvida, definindo as zonas aquiferas e buscando o local mais propício à perfuração do poço, a probabilidade de obter-se boa vazão aumenta significativamente.

Este trabalho mostra a metodologia aplicada ao estudo hiarogeológico de rochas precambrianas com manto de intemperismo em uma área piloto contida na 5a. Região Administrativa, buscando caracterizar as conđições de corrência das ãquas subterrâneas e avaiiar as obras de caplăcão.

A pesquisa está vinculada do Projeto "midrogeologia de Rochas Fraturadas precambrianas no Estado de são paulo", realizada no centro de Pesquisas de Aguas subterrâneas CEPAS/USP, sendo financiada pelo FINEP/PADCT, através do Processo no 42.86 .049200 . 


\section{1 - Considerações Gerais}

o dominio hidrogeológico cristalino representa cerca de 58 \& do território nacional. Observa-se que, dos $5.340 .000 \mathrm{~km}^{2}$ de rochas i.gneas e metamórficas aflorantes, aproximadamente 858 possuem manto de intemperismo que chega a ter 150 metros de espessura (CAVALCANTE \& REBOUCAS, 1989) e, neste caso, as falhas e/ou fraturas podem constituir prolongamentos em profundidade do aquífero que este manto representa.

A pesquisa hidrogeolögica no Brasil, dentro do contexto de rochas cristajinas précambrianas, desenvolveu-se à partir de 1960 quando iniciaram-se os primeiros trabalhos técnicos no semiárido do Nordeste através da Superintendência do Desenvolvimento do Nordeste - SUDENE, buscando suprix a crescenté necessidade de àgua na região. O prëcambriano com manto de intemperismo é predominante nas regiões centro-sul, sul e sudeste do Brasil. onde as condições climáticas favorecem a ação do intemperismo químico, propiciando o desenvolvimento do pexfil de alteracão porēm este contexto ainda é pouco estudado hidrogeologicamente, destacandorse o Relatörio do Departamento de Aguas e Energia Elétrica - DAEE (1981) e BERTACHINI (1987).

As vazões médias dos poços nos aquiferos fraturados são da ordem de $3 \mathrm{~m}^{3} / \mathrm{h}$, com mäximo em torno de $10 \mathrm{~m}^{3} / \mathrm{h}$, pequenas, no gerai, quando comparadas com as obtidas em regiões onde o manto de alteração é significante, as quais oscilam em mëdia entre 10 e $20 \mathrm{~m}^{3} / \mathrm{h}$, alcançando valores de até $70 \mathrm{~m}^{3} / \mathrm{h}$.

\section{2 - Kocalização da Axea}

A ärea piloto escolhida para estudo abrange $590,4 \mathrm{~km}^{2}$ e está situada na bacia hidrográfica do rio Atibaia, Folha SF.23.C.III-2/MI 2767-2. ATIBAIA, escala 1:50.000, IBGE/EMPLASA (1984), a sudeste do Estado de são paulo e é delimitada pelas coordenadas geográficas de 23000' a 23015' de Latitude sul e $46830^{\prime}$ a $46845^{\prime}$ de Longitude Oeste (Figura 01). O acesso é dixeto 


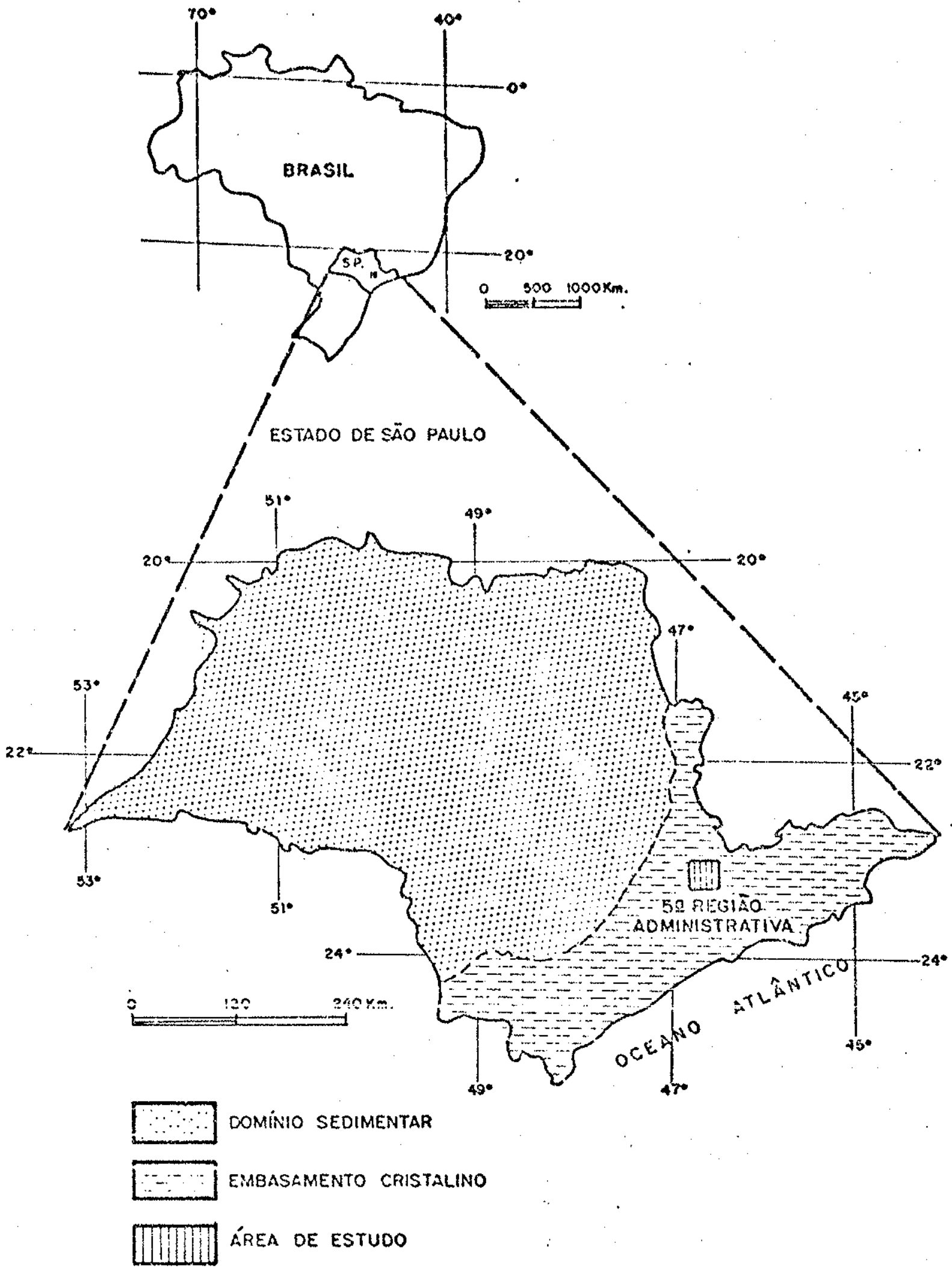

Figura 01 - Mapa de localizaçäo da área de estudo 
através da Rodovia Fernão Dias (BR-381) ou, indiretamente, pela Rodovia D. Pedro I $(S P-065)$.

A razão desta escolha está baseada no fato desta área preencher as caracteristicas exigidas para o estudo no que diz respeito aos aspectos morfo-estruturais, litológicos, distribuicão dos pontos d'água e existēncia de manto de intemperismo.

\section{3 - objetivos}

O presente trabaj.ho tem os seguintes objetivos técnicocientificos:

a) Caracterizax as condições de ocorrência das águas subterrâneas na área piloto;

b) Avaliar os critérios de locação, perfuracão, completacão e desenvolvimento das obras de captação, e;

c) Desenvolver e propor metodologia de estudo hidrogeológico adequada à prospecção de zonas aquiteras no dominio de rochas cristalinas com manto de intemperismo.

\section{2 - METODOLOGIA DE TRABALHO}

A metodologia utilizada constou das seguintes etapas:

\section{1 - Desquisa Bibliográfica}

- levantamento bibliográfico teve por objetivo coletar dados sobre os aspectos sócio-econômicos, fisio-climáticos, geológicos e hidrogeológicos da região,

Esta etapa resultou en um grande acērvo de titulos e mapas, geológicos e planimaltimétricos na escala 1:50.000, que 
serviram de base para o estudo. Ressaltamse que o entendimento e uso deste levantamento gerou um conhecimento generalizado das caracteristicas da área estudada.

Dentre os trabalhos a nivel regional, destaca-se EBERT (1968) que definiu o Grupo Amparo no dominio do Bloco Jundiai e SCHOBBENHAUS FILHO (1981) que propôs a designação de complexo Amparo em face da existência de núcleos rochosos ainda não caracterizados dentro do Amparo; WERNICK et al (op. cit.), CAVALCANTE et al (1979), HAMA et al (1979), ARTUR (1980) e WERNICK et al (1981) trabalharam com dataçōes radiométricas no âmbito do Amparo e dos macicos graniticos do Bloco Jundiaí.

Localmente, ressalta-se os trabalhos de CARVALHO et al (1975) que fizeram o levantamento pedológico semi-detalhado do municipio de Atibaia, OLIVEIRA et al (1985) e MORAIEs et al (1985) com estudos geológicos da Quadrícula de Atibaia, escala $1: 50.000$.

Pertinente a hidrogeologia, vale salientar o trabaiho a nivel regional do Departamento de Aguas e Energia Elétrica - DAEE (1981) que fez o estudo hidrogeológico da 5 a Região Administrativa do Estado de são Paulo - CAMPINAS, na qual esta inserida a ārea ora pesquisada, e BERTACHINI (1987) que estudou en detalhe a região de Jundiai, relacionando as caracteristicas aquifieras aos aspectos geológico-estruturais, geomorfológicos e fisiomclimaticos.

\section{2 - Interpretacão Fotogeológica e Geologia de Campo}

o uso de fotografia aérea è uma prática já consagrada em estudos hidrogeológicos e quando utilizada para pesquisa em terrenos cristalinos busca, especificamente, mapear as estruturas mais favoráveis a ocorrência de água subterrânea. Tsto estä associado a premissa de que no cominio das rochas cristalinas, as zonas de fraturas, contatos entre corpos rochosos e outras formas 
de descontinuidades, ampliam sensivelmente as condiçöes de permeabilidade primäria.

Em um dominio de rochas cristalinas com manto de alteração o trabalho de foto-interpretacão é dificultado, pois este manto mascara as estruturas mas, por outro lado, isto é promissor, pois ele poderá funcionar como aquifero principal ou de transferência.

- trabalho foi realizado com fotografias aéreas nas escalas de 1:25.000 e 1:60.000, buscando mapear as falhas e fraturas existentes e relacioná-las aos aspectos litológicos, geomorfológicos e arenagem superficial. .

Desta fase resultou a base geológica na escala 1:50.000. A seguir se procedeu un controle de carpo dos elementos interpretados e coleta de dados especificos sobre os pontos d'àgua.

Foi realizada uma fase de campo que teve por objetivo fazer 0 controle dos aspectos geológicos e ievantar, especificamente, medidas de atitudes de fraturas. Elas foram tomadas em diferentes afloramentos e sempre observando, desde que possivel, se eram abertas ou fechadas, preenchidas e, neste caso, qual a composição do preenchimento.

Estas medidas complementaram o mapa foto-interpretado e serviram para a elaboraça de diagramas estruturais que foram interpretados sob o ponto de vista do contexto tectônico geral e por unidade litológica, possibilitando uma melhor compreensão da tectōnica rúptil que atuou na região.

Em tese, o fraturamento facilita a ação do intemperismo pois possibilita uma maior percolação da água através dos planos de cizalhamento e produz, consequentemente, um aumento da superfície especifica do contato água/rocha que é responsável direta pelo aumento substancial das espessuras de rochas alteradas. 
- mapa de fraturas é importante na interpretacão dos perfis de alteraço, desde que seja correlacionado aos mapas litológico e de drenagem superficial. Ainda, quando superposto ao mapa de drenagem permitirá dizer até que ponto existe uma superimposicão dela ao fraturamento, condicão vantajosa paxa a recarga direta das zonas aquiferas.

\section{3 - Cadastro de Pontos d'Agua}

Este cadastro compreendeu o levantamento e localização de poços tubulares, cacimbas e fontes.

- cadastramento de pocos tubulares teve por finalidade obter dados técnicos da obra, caracteristicas hidrodinâmicas das formaçoes aquiferas exploradas, perfil ' litológico e acompanhamento do quadro evolutivo das perfuracões na região.

Este trabalho foi realizado à partir do Relatório do Departamento de Aguas e Energia Elétrica (DAEE), 1981, vexsando sobre a 5a. Região Administrativa do Estado de são paulo (CAMPINAS), que forneceu uma visão da distribuicão espacial dos 62 poços existentes até 1980 .

A seguir, foram obtidas as fichas tëcnicas dos pocos junto a companhias perfuradoras que operam na região, a exemplo da JUNDSONDAS, SAIAGUA e SUPERSONDAS, resultando em um acêtró de 79 fichas de poços tubulares perfurados na área até 1989.

Foram realizadas etapas de campo para localizar pontos d'água, realizar medidas de nivel estätico, $\mathrm{pH}$ e condutividade elétrica da água e obter informações sobre os usos e proteção das āguas subterrāneas.

- conhecimento hidrogeológico foi complementado com um cadastro de pocos escavados (cacimbas) que exploram essencialmente $o$ manto de intemperismo. Atualmente os pocos 
escavados abastecem, a nivel de pequena demanda, quase toda a população rural dos municípios de Atibaia e Jarinu.

Ao fim, foram cadastrados 79 pocos tubulares, 157 pocos escavados e 12 fontes. Todas estas informações foram colocadas no mapa geológico culminando com a elaboracão de uma base geológica e de pontos d'água (Anexo 03).

As medidas de nível estático foram efetuadas com um medidor eletro-sonoro; para o pH e condutividade utilizou-se um phâmetro modelo DIGIMED DMPH-P e condutivimetro $C D-2 P$, ambos portáteis e com leitura digital.

Nem sempre foi possivel efetuar a medida do nivel estätico dos poços tubulares, devido ao fato destes estarem, na maioria das vezes, totalmente lacrados impossibilitando qualquer medição.

\section{4 - Análises Quỉmicas das Âguas Subterrāneas}

As anảlises químicas das águas subterrāneas tiveram por objetivo uma caracterizaço hidroquímica básica e, principalmente, verificar a existencia de relação entre as águas do manto de intemperismo e meio fraturado.

- critério utilizado na selecăo dos poços amostrados baseou-se nos valores de $\mathrm{pH}$, condutividade elétrica e nivel estático associados a litologia, fraturamento, drenagem e ärea de descarga/recarga.

Esta associaça de fatores permitiu uma melhor compreensão quanto a variação da composição iônica pois, fatores como composicão mineralógica, maior ou menor velocidade de fluxo, relaça com águas superficiais, dentre outros, podem influir na concentrậão iônica das āguas subterrâneas. 
As amostras de águas foram coletadas das torneiras, de saídas diretas do sistema de bombeamento, ou com o auxilio de um amostrador manual. As análises de campo compreenderam a determinação de $\mathrm{pH}$, condutividạde elëtrica específica, bicarbonato e $\mathrm{CO}_{2}$ livre.

As amostras eram acondicionadas em garrafas plästicas de um litro, hermeticamente fechadas, xotuladas e conservadas no gelo. As análises foram realizadas nos Laboratórios do CENA/Piracicaba e CEPAS/USP. Ao todo foram analisadas 19 amostras, sendo 11 de águas dos pocos tubulares e 8 dos pocos escavados.

\section{5 - Implantação de Piezōmetros Multiniveis}

Uma primeira análise das medidas de $\mathrm{pH}$, condutividade elétrica e nivel. estático mostrcu que em muitos casos existe uma estreita relação entre as águas do manto de intemperismo e meio fraturado.

Partindo-se do principio de que pode existir fluxo das águas do manto para o fraturado, è lógico se pensar que o nivel estático de um poço sofrerá reflexo de um bombeamento realizado em um poço tubular, descle que este esteja situado a uma distância que permita a interferência.

Procurando verificar o grau de transferência d'ägua do manto de intemperismo para o meio fraturado e, se possivel, qual - nivel litológico alterado que mais contribui, foi que se procedeu a implantação de 3 piezômetros multiniveis.

Cada piezômetro foi instalado próximo a um poço tubular (Figuras 02, 03 e 04). O critério de escolha desses poços se baseou no perfil litológico, fraturamento, morfologia e facilidade de acesso do maquinário de perfuração ao ponto escolhido. 


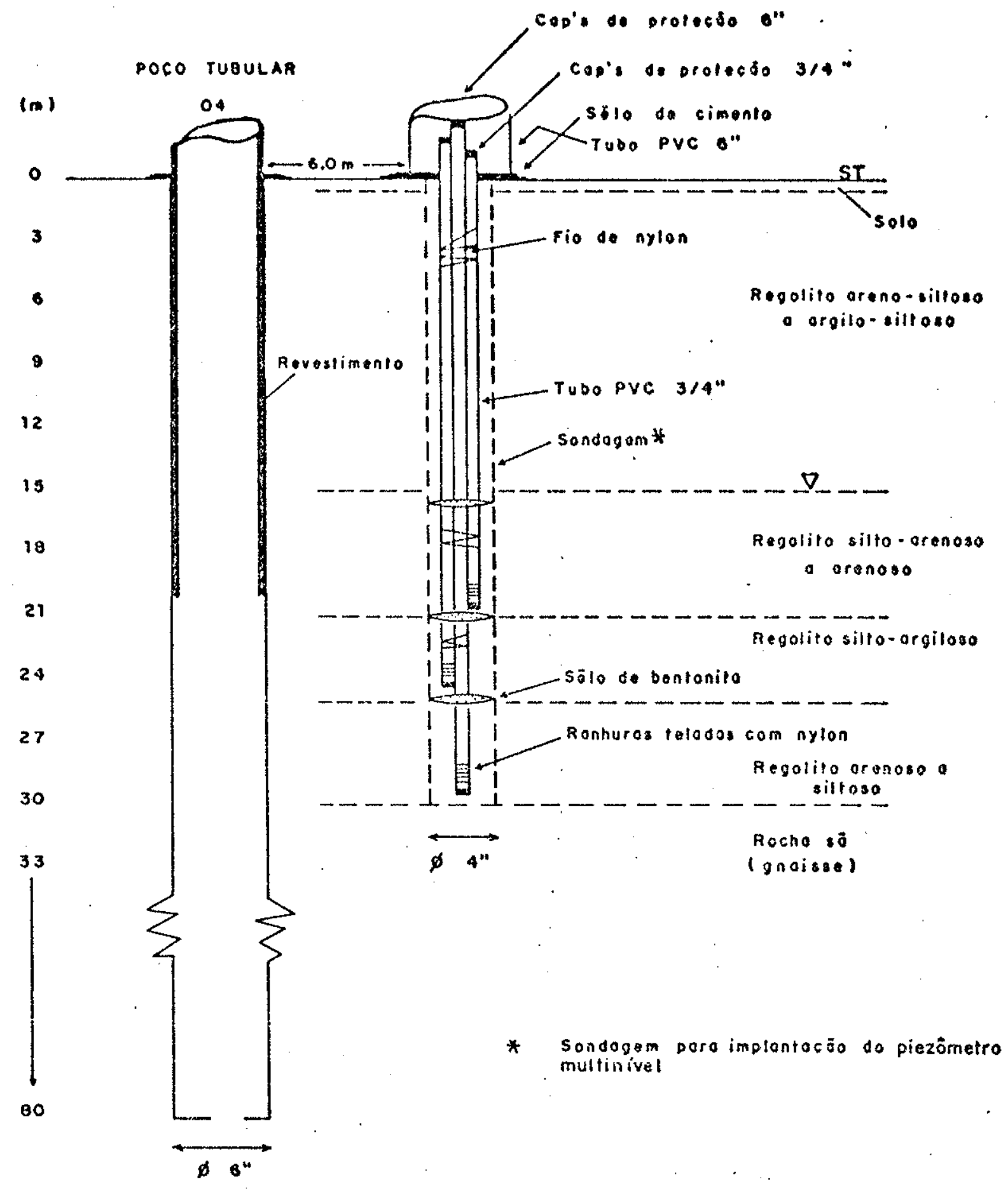

Figuro 02 - Piezōmetro multinivel $\mathrm{N}=1$

Locol: Associacōo Beneficiente Nosso Lor

Atibaio (SP) 


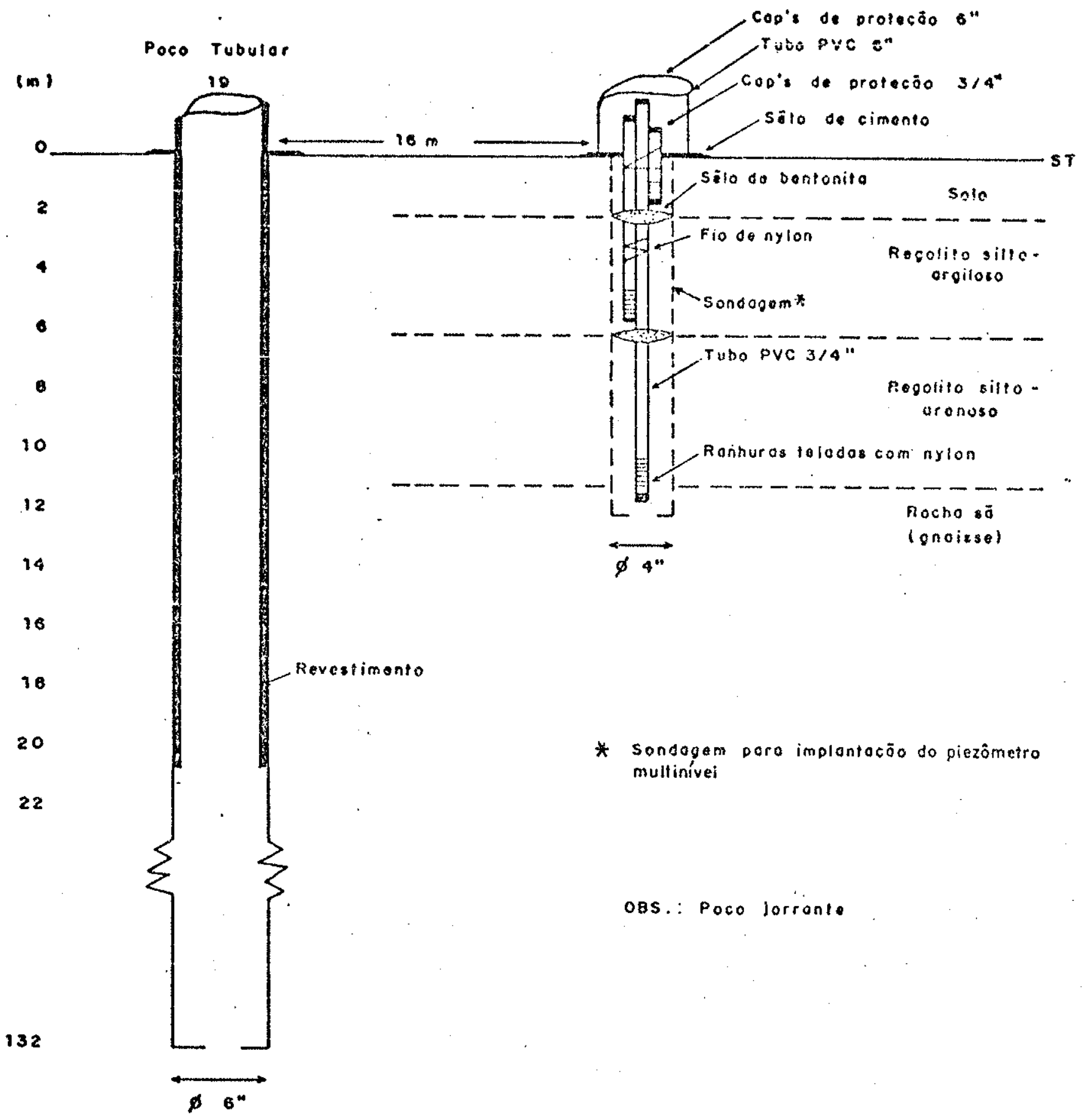

Figura 03 - Piezömetro multinivel $\mathrm{N}^{\circ} 2$ Locol: Sitio Doll Anese Atiboio (SP) 


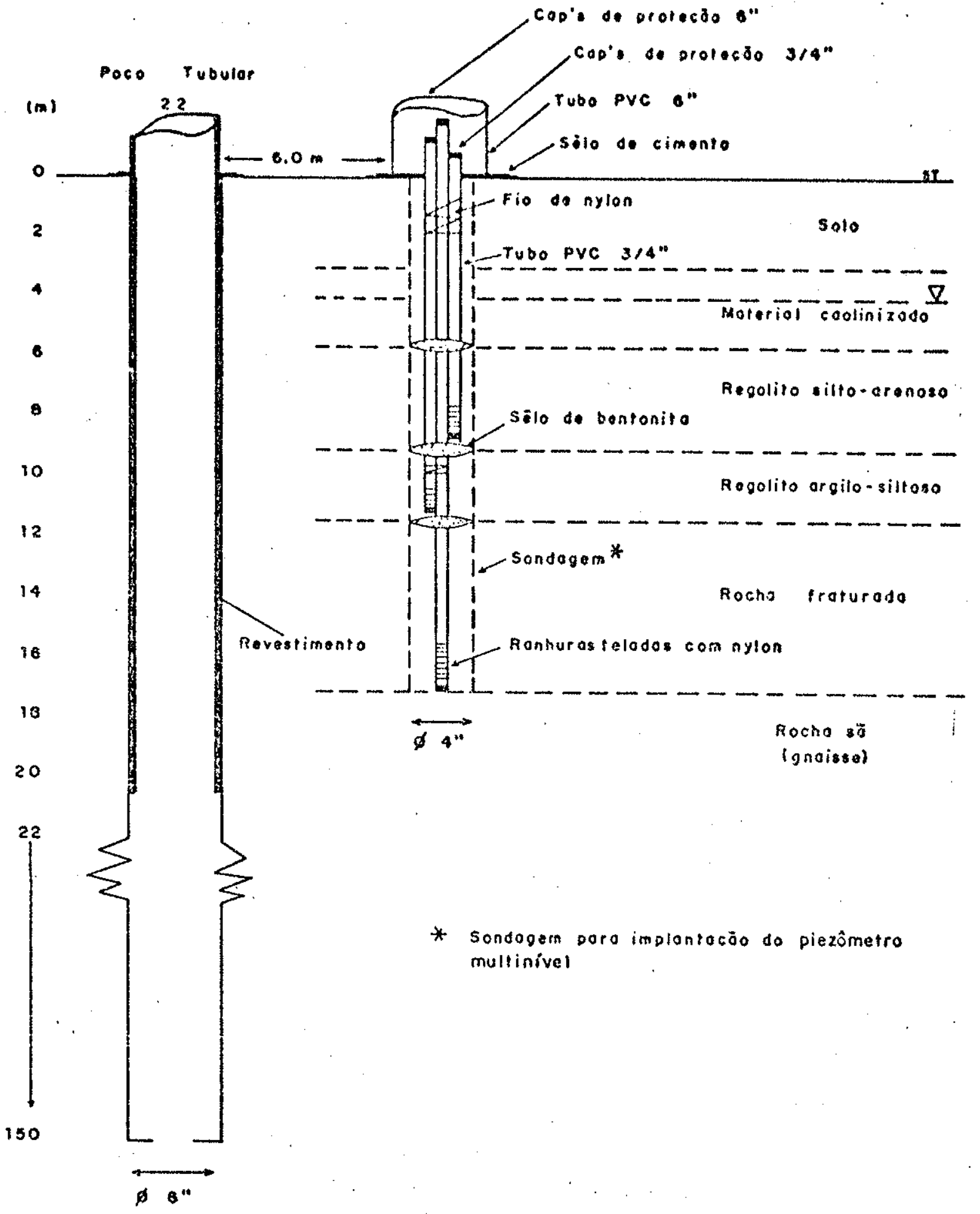

Figura 04 - Piezömetro multinivel N* 3 Local: Sitio Sontinho Alibula (SP) 
- roteiro metodológico de perfuração e instalacão dos piezômetros pode ser sumarizado da seguinte forma:

a) Perfuração com trado mecānico até alcançar o nivel d'água. As amostras de rochas foram descritas e acondicionadas em sacos plásticos, lacrados e rotulados;

b) Perfuração com sonda rotativa, modêlo SS-21 SONDEQ (Foto 01), de um furo com diāmetro de 4" até o contato com a rocha sã. A amostragem seguiu o procedimento anterior;

c) Lavagem do furo a fim de retirar o máximo de detritos do interior do revestimento;

d) Colocação do piezômetro multinivel, sendo a montagem do sistema feita externamente (Foto 02); cada tubo de PVC era ranhurado, à partir da base, em uma extensão de um metro. As ranhuras exam descontinuas com espaçamento de 1,5 a $2,0 \mathrm{~cm}$, perpendiculares ao comprimento do tubo e com abexturas de aproximadamente 1,5 mm. Cada tubo do piezômetro destinava-se a monitorar um nivel alterado;

e) Retirada do revestimento e preenchimento do espaco vazio com areia grossa, essencialmente quartzosa, servindo de pré-filtro;

f) Proteção do piezômetro com tubo PVC e cap's de 6" (Foto 03) e, por ültimo;

g) Proteção do sistema com sêlo de cimento.

$\mathrm{Na}$ confeccão dos piezômetros foi utilizado o seguinte material:

- Tubo plástico rígido PVC de 3/4'', ponta e bolsa. 


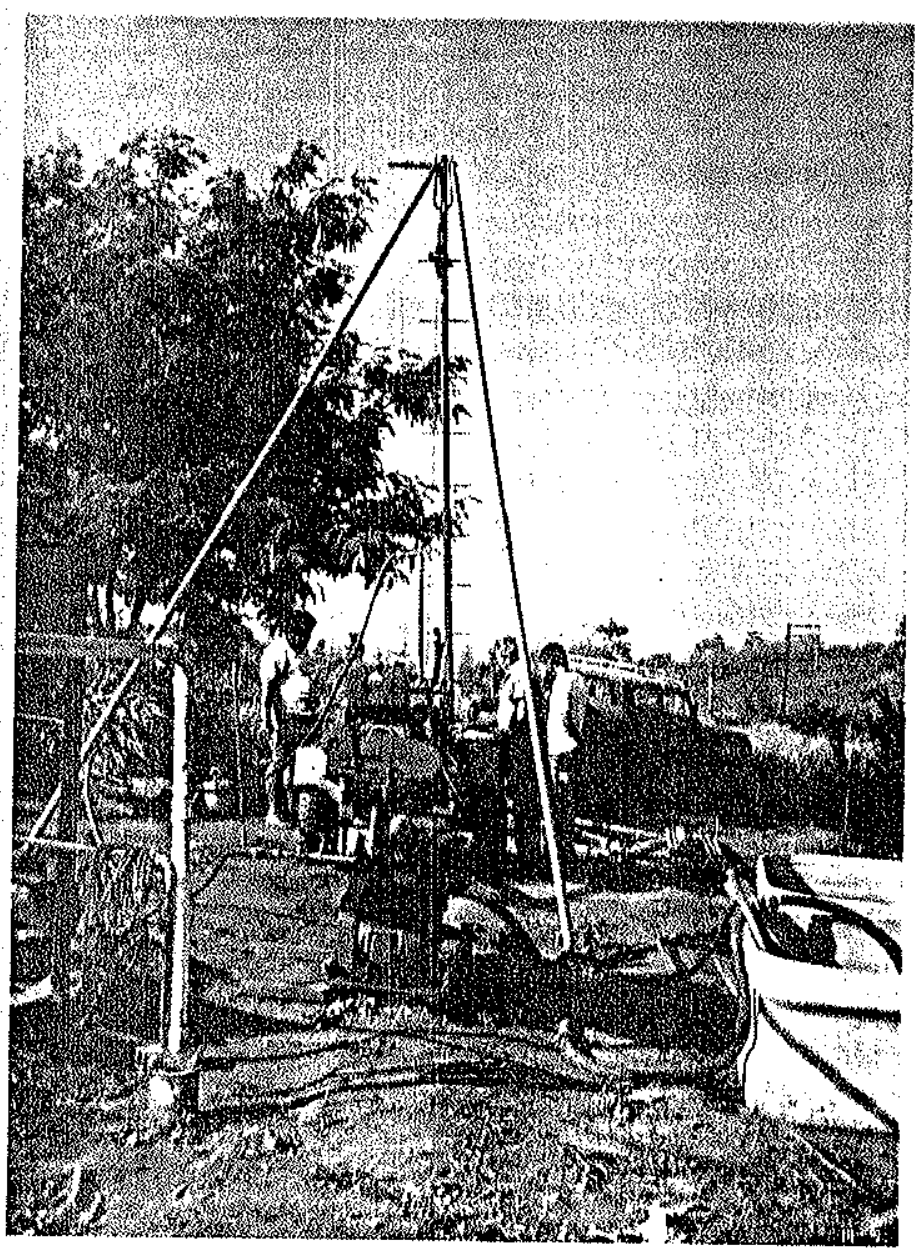

Foro 01 - Perfuração com sonda rotativa, "Modelo ss-21 SONDEQ. Observa-se tambēm; um poço tubular sem a laje de proteção.

LoCAI - Associąão Beneficiente Nosso Lar - Atibala (SP). 


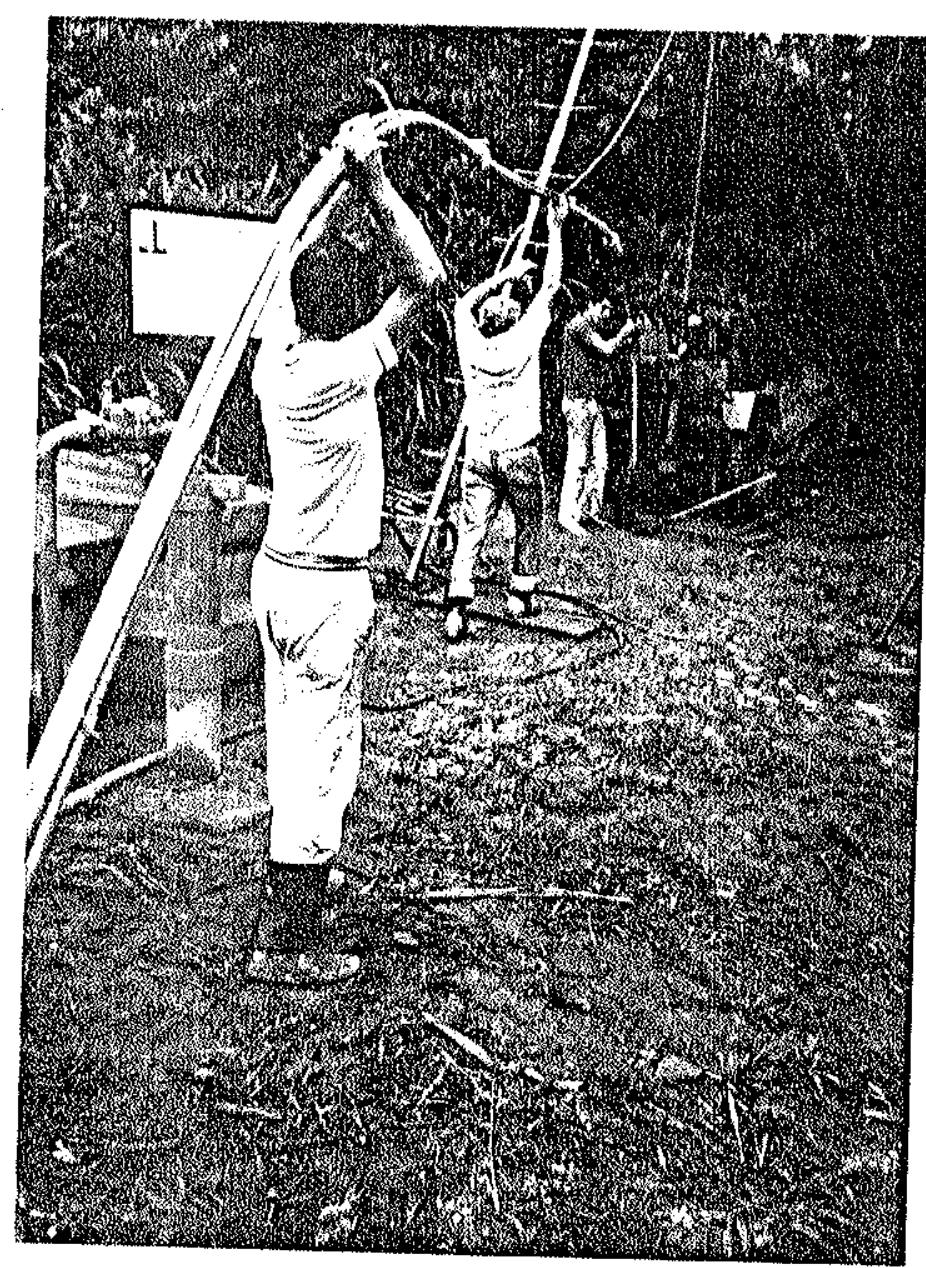

FoTo 02 - Colocação do piezômetro multinivel.

LOCAI. - Sitio Santinha - Atibaia (SP). 


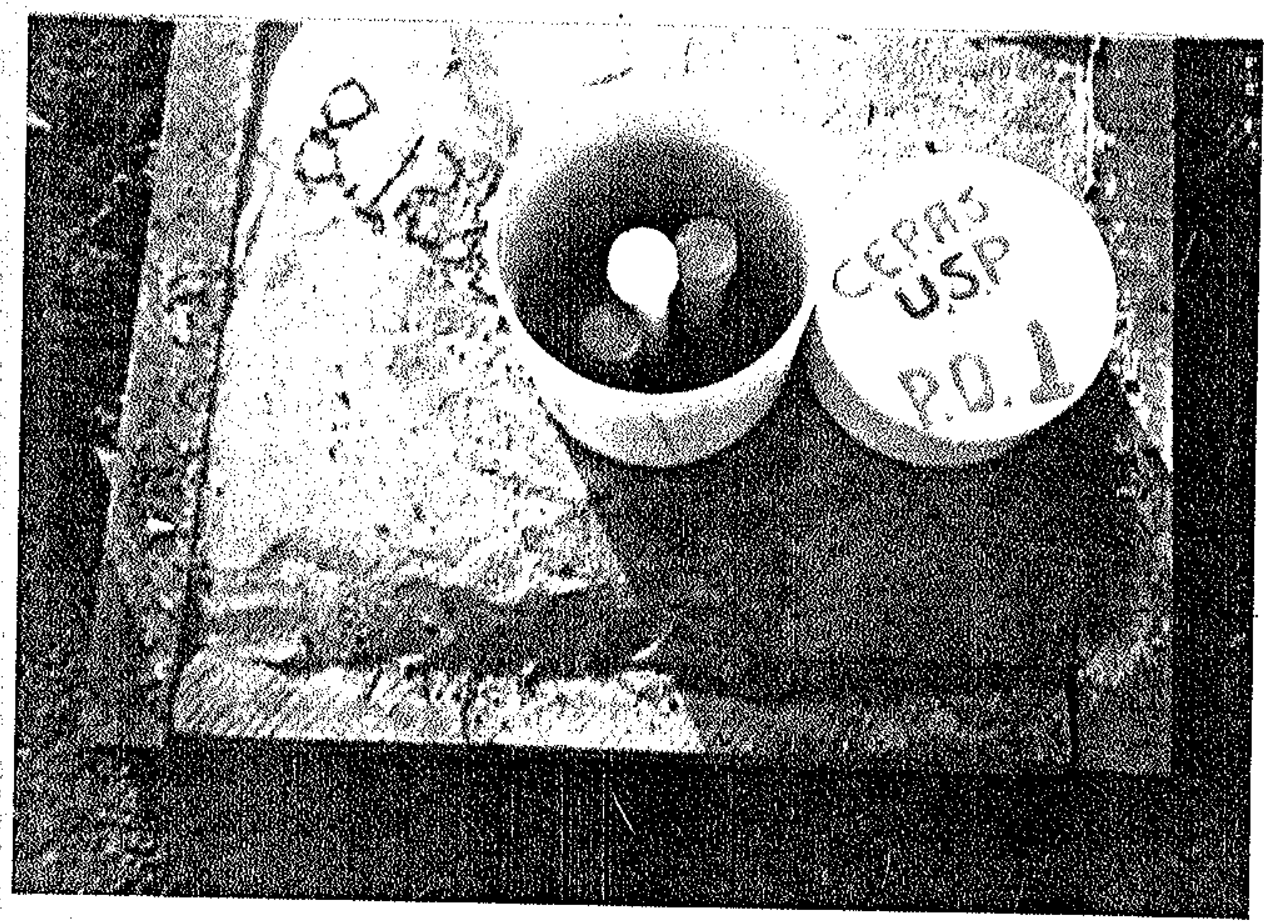

FoTo 03 - Tubo externo de PVC (6") "e tampa de proteção do piezômetro multinível.

Local - Sitio Dall'Anese - Atibaia (SP). 
- Cap's de proteção de $3 / 4$ ', inferior e superior. A primeira foi colada e a segunda foi encaixada, permitindo sua retirada para medição do nivel estático.

- Sêlo de bentonita para isolar os diferentes niveis alterados.

- Tela de nylon, servindo como envoltório das ranhuras e protegendo as mesmas contra a migração de partículas. Evita-se, assim, o entupimento das ranhuras.

- Tubo de PVC de 6''e respectiva cap's de proteção superior, resguardando a obra contra usos inadequados. A cap's foi somente embutida, podendo ser retirada para se medir o nivel estático.

- Os tubos eram unidos com fio de nylon e concentravamse, desta forma, em um só 'feixe'".

Após a instalação de cada piezômetro, eram realizadas medidas do nivel estático utilizando-se um medidor de nivel manual e eletro-sonoro. Inicialmente eram realizadas medidas sem interferencia de bombeamento e depois, com o sistema de bombeamento ligado foram efetuadas medidas a intervalos de tempo pré-determinados atē a estabilização do nível estático. os dados relativos as medidas realizadas estão na tabela 01 .

\section{3 - INTERPRETAÇAO DOS DADOS}

\section{1 - Aspectos Fisio-Clináticos}

A região situa-se em un contexto serrano denominado de Planalto Atlântico, com altitudes mais frequentes entre 700 e 1.000 metros. Três tipos geomorfológicos são distinguiaios: relevos montanhosos, de morros e de agradação. 


\begin{tabular}{|c|c|c|c|c|c|c|c|c|}
\hline \multicolumn{3}{|c|}{ PIEZONEIRO NO OI } & \multicolumn{3}{|c|}{ PIEZOMETRO NO 02} & \multicolumn{3}{|c|}{ PIEZOMETRO NO O3 } \\
\hline$t(\min )$ & SISTEMA & $\begin{array}{l}N . E . \\
(\mathrm{m})\end{array}$ & $t(\min )$ & SISTEMA & $\begin{array}{l}N . E . \\
(m)\end{array}$ & $t(m i n)$ & $\begin{array}{c}\text { SISTEMA } \\
\star \star \\
\end{array}$ & $\underset{(m)}{N . E .}$ \\
\hline$t=0$ & $\begin{array}{l}7 \\
1 \\
2 \\
3\end{array}$ & $\begin{array}{l}15,64 \\
16,00 \\
16,85 \\
17,00\end{array}$ & $t=0$ & $\begin{array}{r}1 \\
2 \\
3\end{array}$ & $\begin{array}{l}+0,87 \\
+0,52 \star \\
+0,38 \\
+0,37\end{array}$ & $t=0$ & $\begin{array}{r}\mathrm{PE} \\
1 \\
2 \\
3\end{array}$ & $\begin{array}{l}5,12 \\
4,23 \\
4,16 \\
4,19\end{array}$ \\
\hline$t=30$ & $\begin{array}{l}1 \\
2 \\
3\end{array}$ & $\begin{array}{l}17,75 \\
17,00 \\
17,00\end{array}$ & $t=10$ & $\begin{array}{r}\text { PT } \\
1 \\
2 \\
3\end{array}$ & $\begin{array}{r}5,25 \\
+0,22 \\
+0,35 \\
+0,36\end{array}$ & $t=10$ & $\begin{array}{l}\text { PE } \\
\text { I } \\
2 \\
3\end{array}$ & $\begin{array}{l}5,16 \\
4,22 \\
4,13 \\
4,16\end{array}$ \\
\hline$t=40$ & $\begin{array}{l}1 \\
2 \\
3\end{array}$ & $\begin{array}{l}18,05 \\
17,00 \\
17,02\end{array}$ & $t=20$ & $\begin{array}{r}P 1 \\
1 \\
2 \\
3\end{array}$ & $\begin{array}{l}5,54 \\
0,82 \\
0,40 \\
0,42\end{array}$ & $t=20$ & $\begin{array}{l}\text { PEE } \\
1 \\
2 \\
3\end{array}$ & $\begin{array}{l}5,16 \\
4,23 \\
4,13 \\
4,16\end{array}$ \\
\hline$t=50$ & $\begin{array}{l}1 \\
2 \\
3\end{array}$ & $\begin{array}{l}18,27 \\
17,10 \\
17,50\end{array}$ & $t=30$ & $\begin{array}{r}\mathrm{PT} \\
1 \\
2 \\
3\end{array}$ & $\begin{array}{l}5,35 \\
1,02 \\
0,43 \\
0,44\end{array}$ & $t=30$ & $\begin{array}{c}\mathrm{PE} \\
1 \\
2 \\
3\end{array}$ & $\begin{array}{l}5,18 \\
4,23 \\
4,14 \\
4,17\end{array}$ \\
\hline$t=60$ & $\begin{array}{l}1 \\
2 \\
3\end{array}$ & $\begin{array}{l}18,37 \\
17,12 \\
17,50\end{array}$ & $t=40$ & $\begin{array}{l}\text { PT } \\
1 \\
2 \\
3\end{array}$ & $\begin{array}{l}6,00 \\
1,31 \\
0,48 \\
0,48\end{array}$ & $t=40$ & $\begin{array}{r}P E \\
1 \\
2 \\
3\end{array}$ & $\begin{array}{l}5,16 \\
4,22 \\
4,13 \\
4,16\end{array}$ \\
\hline$t=70$ & $\begin{array}{l}1 \\
2 \\
3\end{array}$ & $\begin{array}{l}18,48 \\
17,17 \\
17,80\end{array}$ & $t=50$ & $\begin{array}{r}\mathrm{PT} \\
1 \\
2 \\
3\end{array}$ & $\begin{array}{l}6,17 \\
1,49 \\
0,53 \\
0,53\end{array}$ & $t=50$ & $\begin{array}{l}\mathrm{PE} \\
1 \\
2 \\
3\end{array}$ & $\begin{array}{l}5,17 \\
4,21 \\
4,14 \\
4,17\end{array}$ \\
\hline$t=80$ & $\begin{array}{l}1 \\
2 \\
3\end{array}$ & $\begin{array}{l}18,53 \\
17,14 \\
17,28\end{array}$ & $t=60$ & $\begin{array}{r}\mathrm{PT} \\
1 \\
2 \\
3\end{array}$ & $\begin{array}{l}5,24 \\
1,78 \\
0,58 \\
0,58\end{array}$ & $t=60$ & $\begin{array}{r}\mathrm{PE} \\
1 \\
2 \\
3\end{array}$ & $\begin{array}{l}5,17 \\
4,21 \\
4,14 \\
4,17\end{array}$ \\
\hline$t=90$ & $\begin{array}{l}1 \\
2 \\
3\end{array}$ & $\begin{array}{l}18,63 \\
17,16 \\
17,17\end{array}$ & $t=80$ & $\begin{array}{l}\text { PI } \\
1 \\
2 \\
3\end{array}$ & $\begin{array}{l}6,44 \\
2,09 \\
0,73 \\
0,68\end{array}$ & & & \\
\hline & $\cdot$ & & $t=100$ & $\begin{array}{l}\mathrm{PT} \\
1 \\
2 \\
3\end{array}$ & $\begin{array}{l}6,54 \\
2,26 \\
0,70 \\
0,69\end{array}$ & & & \\
\hline & & & $t=120$ & $\begin{array}{l}\text { PI. } \\
1 \\
2 \\
3\end{array}$ & $\begin{array}{l}6,64 \\
2,38 \\
0,82 \\
0,80\end{array}$ & & & \\
\hline
\end{tabular}

$t=$ tempo

PT $=$ poço tubular

$P E=$ poço escavado

$1,2,3=$ tubos que compöen o piezömetro multinál

1 = tubo oe maior comprimento.

2 = tubo de comprimento intermediário

3 = tubo de menor comprimento

* = altura do tubo en superficie

$* *=$ PT em funcionamento.

TABEIA 01 - MEDTDAS DO NIVEL ESTXTICO DOS PIEZOMKTROS NULTINIVEIS B POCOS TUBUILARES MONITORADOS - ATIBAIA (SP) 
0 relevo montanhoso situa-se predominantemente nos dominios graniticos e apresenta altitudes de 1.000 a 1.400 metros, destacando-se do relevo regional a exemplo das serras de Bocaina, Atibaia e Pedra Vermelha a nordeste, leste e sudeste da área, respectivamente.

Morrotes ou colinas mamelonares localizam-se quase que totalmente no Complexo Gnaíssico-Migmatitico, caracterizando-se por altitudes entre 800 a 1.000 metros, constituindo uma superficie erosiva com configuracão bastante ondulada do tipo ' 'mar de morros'' e topos arredondados.

- relevo de agradação é representado por várzeas quaternärias, planicies a nivel de base, com altitudes inferiores a 800 metros, sujeitas periodicamente a inundações, principalmente nas proximidades do rio Atibaia.

- clima é tropical de altitude com temperaturas médias anuais de 22,80 e $13,60 \mathrm{C}$, máxima e minima respectivamente, precipitação média anual de $1.350 \mathrm{~mm}$, evapotranspiração de $919 \mathrm{~mm}$ e umidade relativa de $74 \%$ (CARVALHo et al, 1975). Estes dados refletem uma taxa de excedente hírico de $431 \mathrm{~mm} / \mathrm{ano}$.

A porção da bacia hidrográfica do rio Atibaia estudada representa $22 \%$ da área total de drenagem do Atibaia, inserida na bacia do rio Piracicaba. Limita-se ao norte com a bacia do rio Jaguari e ao sul com a do Jundiai, sendo que o principal curso d'água é o rio Atibaia que atravessa a região de leste para oeste balizado por falhamentos, tendo como afluentes principais na margem direita os ribeirões das Pedras, do Mato Dentro e do Amaral e, na margem esquerda, os ribeirões dos porcos, Laranja Azeda, Folha Larga, Maracanã e Pinhal.

- rio Atibaia possuï um padrão anastomōstico devido a intensa sedimentação sofrida condicionando, consequentemente, a mudanças do posicionamento de seu leito. No geral, seus principais afluentes apresentam configuração retilinea $e$ um 
paralelismo entre si, reflexo da congruēncia com falhas e/ou fraturas.

- padrão de drenagem é dendrítico-retangular, localmente angular, refletindo o carăter litológico $e$ os aspectos rupturais que atuaram na região.

\section{2 - Contexto Geolögico}

As principais litologias existentes na região, em têrmos de aistribuição espacial, pertencem ao Complexo GnaísicoMigmatitico de Amparo e aos macicos graniticos de. Socorro e Atibaia.

\subsection{1 - Complexo Amparo}

Os gnaisses, migmatitos, anfibolitos, granulitos, xistos e metabásicas que ocorrem no domínio do Bloco Jundiaí, foram definidas por EBERT (1968) como Grupo Amparo. Em 1981, SCHOBBENHAUS FILHO reportando-se a existência de possíveis nücleos mais antigos e a supracrustais ainda não perfeitamente caracterizadas e delimitadas no Amparo, propõe para este a designação de Complexc que é utilizada atualmente pela maioria dos autores, entre eles BISTRICHI et al (1981) e MORALES et al (1985), e por esta razão aqui também adotada. Regionalmente é delimitado ao sul pelas falhas de Itu, Jundiuvira e Camanaucaia; ao norte, pela falha de Jacutinga e a oeste é recoberto pelos sedimentos da Bacia do Paraná.

WERNICK et aI (1976) sugerem pelo menos dois ciclos metamörficos tectônicos: a) um ciclo de médio a alto grau correlacionável ao Ciclo Transamazônico, envolvendo a formação do Amparo em condições de fácies anfibolito e granulito, e; b) posterior rejuvenescimento atravēs de remigmatizacão. feldspatização e intrusão de corpos graniticos, no ciclo Brasiliano. 
Dataçōes radiométricas pelo métođo $\mathrm{Rb} / \mathrm{Sr}$ concordam com WERNICK et al (op. cit.), definindo idade Transamazônica para a formação do Amparo (ARTUR, 1980; WERNICK et al, 1981), enquanto que dataçōes através de K/Ar caracterizam os efeitos do Ciclo Brasiliano (HAMA et al, 1979; CAVALCANTE et al, 1979; ARTUR, 1980).

Na ärea estudada o Complexo Amparo abrange $325,5 \mathrm{~km}^{2}$ $(55,5$ \&) e é representado predominantemente por uma unidade gnaissica-migmatitica com intercalações de xistos, anfibolitos, quartzitos e metabásicas.

Entre os gnaisses predominam os quartzo-feldspáticos, granada-biotita gnaisses com ou sem sillimanita, hornblendabiotita gnaisses e tipos cälcio-silicatados. Os tipos bandados são os mais comuns, destacando-se os granada-biotita gnaisses e, secundariamente, ocorre un tipc ''oftáimico'' caracterizado por lentes elipsoidais, milimétricas, orientadas segundo a foliação e sendo compostas por quartzo, felaspatos, biotita, moscovita e, mais raramente, sillimanita e granada.

Gnaisses ricos em biotita e hornblenda se distribuem por toda a ärea. Mineralogicamente são compostos por quartzo, andesina, microclinio, biotita, hornblenda e acessórios lopacos e titanita). As intercalações xistosas são representadas por moscovita ou biotita xistos contendo quartzo, moscovita, biotita, clorita e actinolita, (MORALEs et al, op. cit.).

Os gnaisses passam gradativamente, de oeste para leste, para migmatitos que às poucos, à medida que se caminha para leste, vão exibindo estruturas cada vez mais complexas. A maior parte dos migmatitos é derivada de metassedimentos, com leucossomas resultantes tanto da injeção quanto da anatexia de material granitico, apresentando coloragão rösea a esbranquigada e são constituidos por microclinio, oligoclásio, quartzo, biotita, hornblenda, granada e moscovita (MORALEs et al, op. cit.l. 
Os paleossomas representam composiçōes gnaissicas diversas. As estruturas migmatiticas mais comuns são as acamadas, schilieren, agmatitica e nebulitica.

No dominio gnaissico-migmatitico é comum a presenca de veios quartzosos, fraturados, com larguras de até $50 \mathrm{~cm}$, geralmente concordantes com a foliação mineralógica. MORALEs et al (op. cit.) citam a existência de 'enxames'de veios quartzosos de espessuras que chegam a ser métricas e passiveis de serem lavrados.

\subsection{2 - Maciços Graniticos}

Corpos graniticos com dimensões variadas pontilham a região, formando as proeminências do relevo, sendo que FonsECA et al (1979) englobam esses litótipos em dois maciços, socorro e Atibaia.

o macico de Socorro ocupa uma ārea de $136 \mathrm{~km}^{2}(23 \%) \mathrm{e}$ e representado por corpos de dimensões variadas, equi a inequigranulares, granulação fina a mēaia, colorações rósea, cinza ou esbranquiçada e fortemente cataclasados. O tipo mais comum é o biotita-granito composto por quartzo, feldspato potássico, biotita, hornblenda e, esporadicamente, moscovita.

No noxtc da ärca ccorxe um granito röseo com megacristais de microciinio não orientados, de forma retangular com até $10 \mathrm{~cm}$ de comprimento. Mineralogicamente é composto por quartzo (20-308), microclinio (25-40\%), plagiocläsio (oligoclásio-andesina, 20-30\%) e biotita (10-20\%), aparecendo comumente a hornblenda nos tipos granodioriticos (MORALEs et al, $1985)$.

Ao sul existem granitos de coloração cinza, granulação fina a média, caracterizados pela presença marcante de moscovita. 
CAMPOS NETO et al (1983) denominam de "catapora" ao granito com cristais granatiferos de até $2,0 \mathrm{~cm}$ de diâmetro, compostos macroscopicamente por microclinio, biotita, quartzo e granada. Possuem foliacão cataclāstica e contém xenólitos de material anfibolitico.

Feicões migmatíticas são comuns no maciço de Socorro, representando provavelmente restos não digeridos das encaixantes, ou mesmo do material inicial cuja anatexia originou as rochas graníticas.

WERNICK et al (1978 a,b) atribui ao Ciclo Brasiliano a profusa intrusão de material granitico nas rochas do complexo Amparo.

- maciço granitico de Atibaia ocupa $52,4 \mathrm{~km}^{2}$ (9 \%), ficando esssencialmente localizado na porção sudeste da área, representando a maior expressão topogräfica e tendo seu posicionamento concordante com a foliação regional.

MORALES et al (1985) reportam esta unidade ao Proterozóico superior. Este granito se caracteriza por ser homogêneo, granulação média a grosseira, chegando localmente a ser mito grosseira, e geralmente inequigranular. S composto de quartzo, microclinio, oligoclásio, biotita e hornblenda, possuindo textura cataclástica, estrutura foliada e sendo menos cataclasado do que o maciço de socorro. 


\subsection{3 - Coberturas Coluvionares}

Os sedimentos coluvionares são restritos a manchas de unidades miocênicas a pliocênicas, abrangendo uma área de $23 \mathrm{~km}^{2}$ $(3,98)$.

MORALES et al (1985) denominaram, informalmente, de Formação Tanque aos sedimentos que ocorrem entre as altitudes de 740 a 760 metros, porém as vezes atingindo 800 metros. E constituida por sedimentos arenosos e silto-argilosos de coloração esbranquicađa, possuindo estratificação plano-paralela que, as vezes, torna-se tão finamente laminada que grada para um follhelho.

A Formação são paulo, ou coberturas cenozóicas indiferenciadas correlatas a esta segundo BISTRICHI et al (1981), e representada por sedimentos pouco litificados de coloração variegada, indo desde a amarela ate a vermelha, arenosos a argilosos com intercalações de niveis conglomeráticos. Suas melhores exposições são encontradas na região leste da área.

Não existem dados referentes as espessuras destas coberturas ná área porém, supõe-se pelas observações de campo, que oscilem entre 5,0 a 20,0 metros.

\subsection{4 - Aluviões}

Depósitos aluvionares ocorrem nas calhas das principais drenagens, a exemplo do rio Atibaia, ou dispöem-se em manchas isoladas ao longo das drenagens. secundárias capeando uma superficie de $46 \mathrm{~km}^{2}(7,8 \mathrm{8})$.

A composiç̃o mineralógica destes depósitos é muito variada, em função da litologia percorrida pela drenagem. E comum a presenca de argilas, siltes, areias e cascalho grosseiro predominantemente quartzo-feldspätico. 
Possuem, no geral, poucos metros de espessura porëm, localmente, chegam a 60 metros (DENALVA, 1971). Este autor admite que para a região de Atibaia estes terraços sejam do Plioceno superior, não excluindo a possibilidade de serem mais recentes.

\section{2 .5 - Feições Estruturais}

\subsubsection{1 - Estruturas Dücteis}

A região em apreço se caracteriza pela presença de uma foliação de pequeno ângulo de mergulho, paralela ao plano axial das dobras mais antigas (Fn +1$)$, e pelas ondulações com direções preferenciais WNW $e$ NNE, esta última formando sinformes e antiformes.

A atitude preferencial para a foliação principal ( $\mathrm{Sn}+$ 1) apresenta direção $\mathrm{EW}$ e pequenos mergulhos para $\mathrm{SW}$ e $\mathrm{SE}$. A medida que se caminha para sudeste da área, a direção de $\mathrm{sn}+1$ volta-se mais para NE decorrente da influência do macico granitico de Atibaia.

MORALES et al (1985) definem trës conjuntos de dobras, $\mathrm{Fn}+1, \mathrm{Fn}+2$ e $F n+3$. As primeiras são as mais antigas, onde $s n+1$ é paralela ao plano axial e pertencem a um evento deformacional $\mathrm{nn}+1$, onde a ünica evidência de um evento 
anterior (Dn) é a presença de uma xistosidade dobrada ao longo de $\mathrm{Fn}+1$. Este conjunto abriga dobras centimëtricas a decimëtricas, fechadas e isoclinais, simétricas e assimétricas e geralmente intrafoliares sem raizes. Possuem atitude preferencial em torno de EW/300S com plunge, no geral, de 200 para s100W. Outros māximos de concentração podem ser.visualizados na figura 05, observando-se que todos possuem caimento para SW e SE.

Os minerais do granito de Atibaia estão orientados preferencialmente para NNE, com altos mergulhos para NW, concordante com Sn + 1 na borda do corpo. O contato com a encaixante é marcado por uma zona intensamente deformada, com lineações de estiramentos mineralógicos sub-horizontais. Desta forma, este litótipo é tiđo como sin a tardi-tectônico a $\mathrm{Dn}+1$, ou mais provavelmente, sin a tarai-tectônico aos falhamentos transcorrentes.

Os outros conjuntos de dobras que afetam $\mathrm{sn}+1$ possuem estilos semelhantes, porëm são diferentes em termos de direções axiais e amplitude de dobramento.

Fn +2 envolve dobras suaves e abertas, centimétricas a métricas, sem desenvolver foliação paralela ao plano axial. Em Fn + 3 pode ser verificada a existência de clivagem de fratura paralela ao plano axial, sendo esta feicão posterior a $\mathrm{Fn}+2$.

A rigura 06 mostra as concentrações preferenciais dos eixos, com predomínio das direçóes em torno de $\mathrm{EW}$, atitudes dos eixos de $\mathrm{Fn}+2$, e menores concentrações em torno de NNW e NNE, atitudes de $\mathrm{Fn}+3$. 


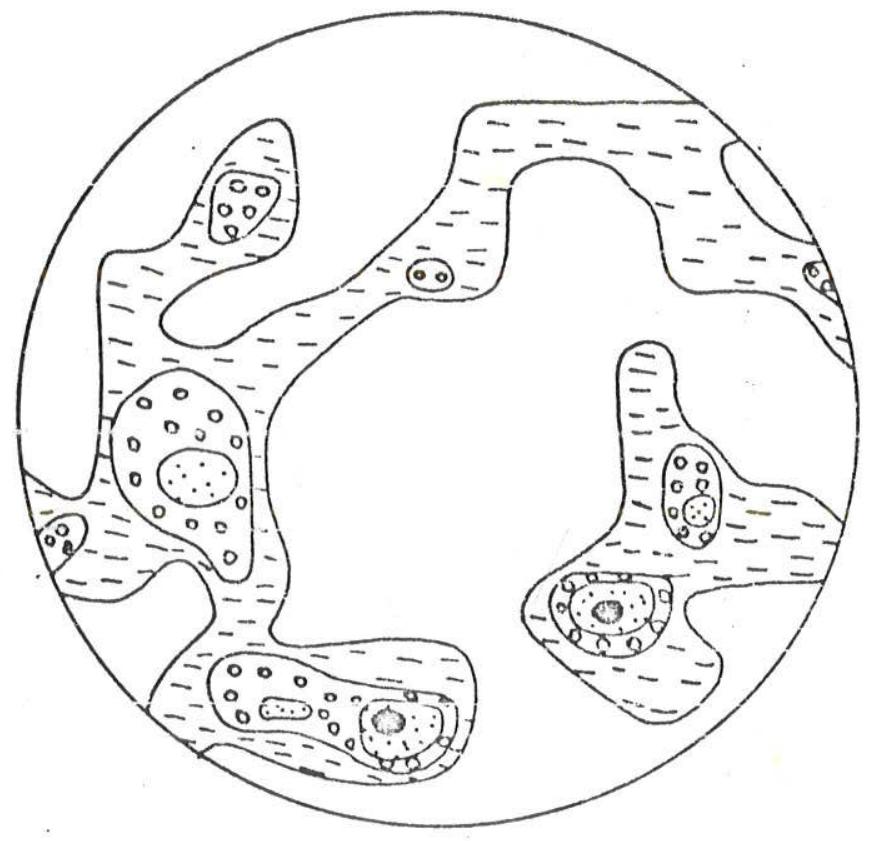

Números de medidas: 55

Móxımos de concentracäo

$N 10^{\circ} \mathrm{E} / 20^{\circ} \mathrm{SW}$ $\mathrm{N} 40^{\circ} \mathrm{W} / 30^{\circ} \mathrm{SE}$ NTOW/30 $/ 3 E$ NBO E / $35^{\circ} \mathrm{S}$ W

Figura 05 - Diagrama de frequencia dos polos dos eixos das dobras $\mathrm{Fn}+\mathrm{l}$ (Proj. Hem. Inf.) (morales et al 1985)

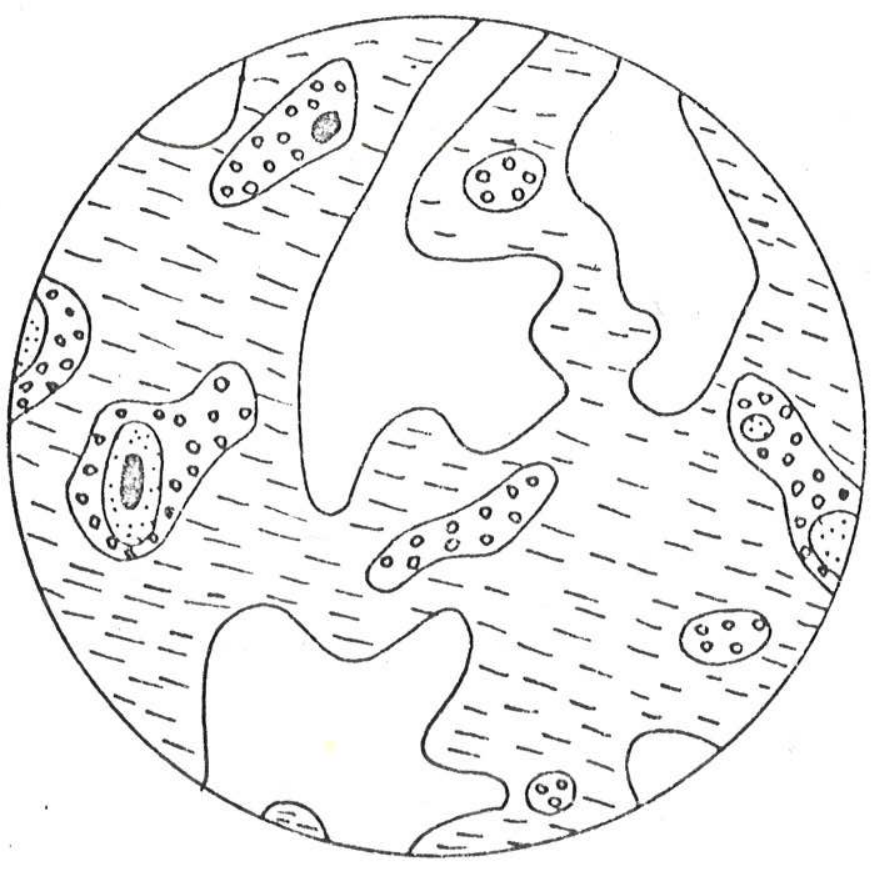

Números de medidas: 120 Máximos de concentroçōo N $80^{\circ} \mathrm{E} / 26^{\circ} \mathrm{SW}$ N90 $\mathrm{E} / 22^{\circ} \mathrm{E}$ N $75^{\circ} \mathrm{W} /$ Horizontal $\mathrm{N} 20^{\circ} \mathrm{W} / 20^{\circ} \mathrm{NW}$

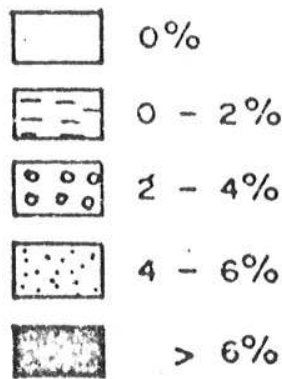

Figura 06 - Dlagrama de frequëricia dos polos dos eixos das dobras da foliasão principal, área total. (Proj. Hem. Inf.) 
$\mathrm{Fn}+2$ possui planos axiais com direcões preferenciais pröximas a EW com grandes mergulhos para sul e norte. Fn + 3 possui direções $\mathrm{N}-\mathrm{S}$ com mergulhos sub-verticais.

$\mathrm{Fn}+3$ é caracterizado por dobras em escala regional, representando grandes sinformes e antiformes com eixos caindo para SSW. Estas estruturas podem sex observadas na porção NE da área estudada.

\subsubsection{2 - Estruturas Rúpteis}

A região leste do Estado é recortada por inúmeras falhas com extensōes de centenas de quilômetros, atitudes subverticais e espessas zonas cataclästicas. Elas foram ativas no fim do Brasiliano com caráter transcorrente e se sujeitaram a movimentos normais durante a Reativação Wealdeniana da plataforma Sulamericana (HASUI et al, 1977).

Na região de Atibaia são encontradas evidẽncias de falhas e fraturas por toda parte, dadas pela presença marcante de zonas cataclasadas e superficies estriadas, alëm da congruência, frequentemente, de falhas ou fraturas com as maiores drenagens.

Foram levantadas em campo 775 medidas de atitudes de fraturas, obtidas em litologias diferentes e em diversos afioramentos. O diagrama da figura 07 mostra a predoninânia de dois sistemas de fraturas, sendo um com direção N500 a $550 \mathrm{E}$ e outro com $N 458$ a $60 \%$ W. Um terceiro, de menor expressão, situa-se praticamente a $\mathrm{E}-\mathrm{W}$.

As medidas foram plotadas em diagramas de projecão estereogräfica equiärea, gerando diagramas de contôrno. o tratamento foi realizado a nivel geral e por unidade litológica. 
A figura 08 mostra que na região estudada existem planos preferenciais de fraturas com atitudes N490W, N530W e N440 $\mathrm{E}$, todos com mergulhos subverticais.

A figura 09. A representa a distribuiçäo dos polos das atitudes de fraturas obtidas nos granitos socorro e observa-se que os planos preferenciais de fraturas existentes nesta litologia situam-se com direcões $N 48 \% \mathrm{~W} /$ subvertical, N460W/820SW e N50 QE/78 QSE.

A figura 09.B mostra as concentraçes preferenciais dos polos das atitudes de fraturas do Complexo Amparo, que refleter planos de fraturas situados entre $1300 \mathrm{O}$ a $\mathrm{N} 55 \mathrm{OW}$ com mergulhos subverticais e, secundariamente, um plano com atitude $N 44 \%$ E/subvertical.

Para o macico granitico de Atibaia foram tomadas apenas 15 medidas de atitudes de fraturas, nümero este insuficiente para a elaboraça de diagrama estrutural. Porém, os planos medidos possuem atitude geral de $\mathrm{N} 48 \mathrm{OW} / \mathrm{subvertical.}$

Desta forma, existe uma predominância de planos de fraturas com atitudes em tôrno de N50ow/subvertical, secundado por N48 OE/84 OSE.

A principal falha representa a continuidade da Falha de Extrema (CAMPOS NETO et al, 1984) e atravessa toda a área de estudo com direção geral N35oE. Ao longo de toda sua extensão observa-se rochas cataclasadas chegando a constituir, por vezes, faixas com 15 metros de largura. MORALEs et al (1985) observaram dois máximos de concentração, N250E/850SE e N560E/80oNW, para a foliacão milonitica e para as estrias foram obtidas atitudes preferenciais de N300E/100SW e N450E/450SW, podendo indicar dois tipos de deslocamentos, sendo um de rejeito horizontal e outro obliquo. 


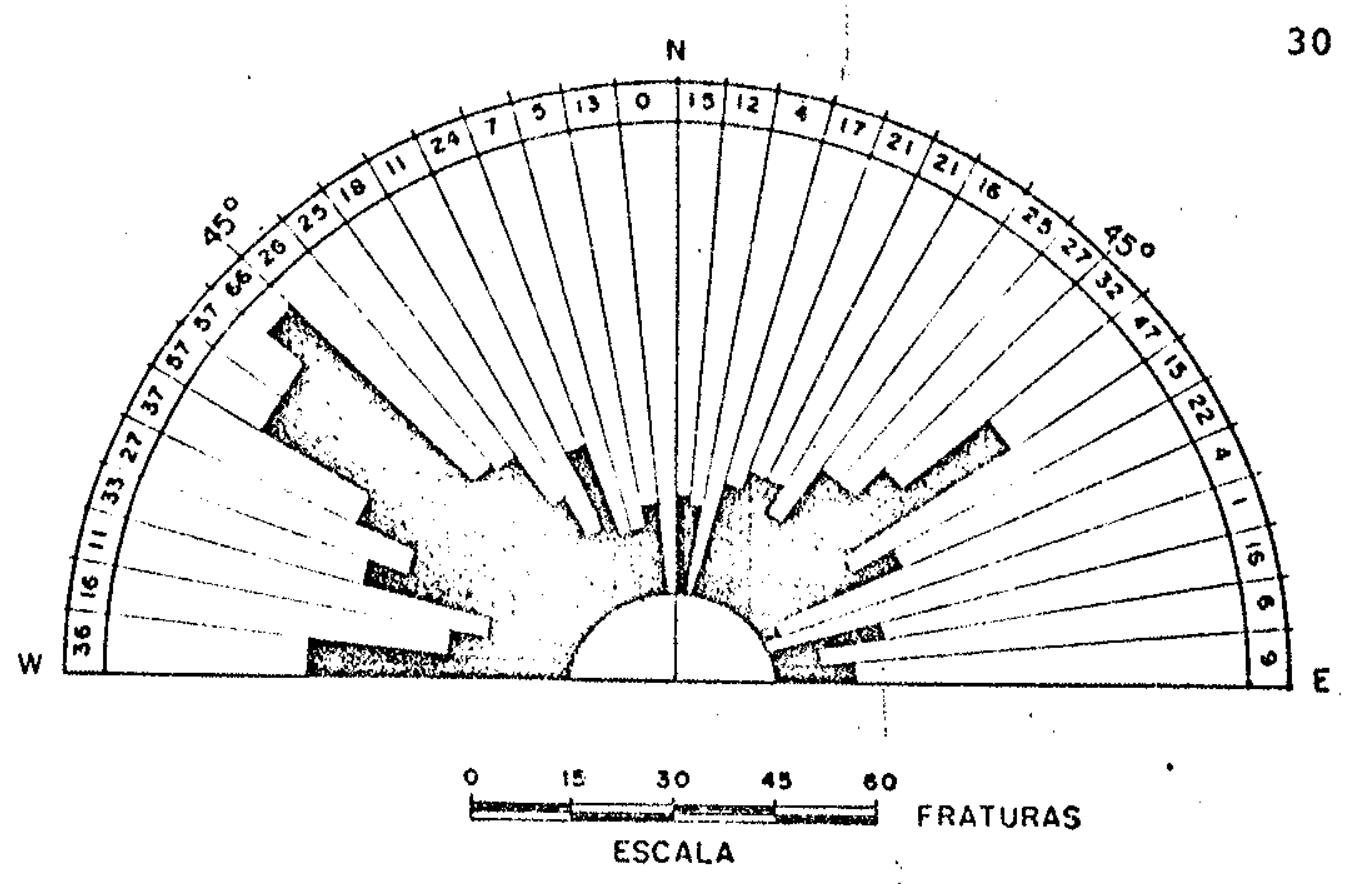

Figura 07 - Diagrama de roseta das direçöes de fraturas Atibaia (SP)

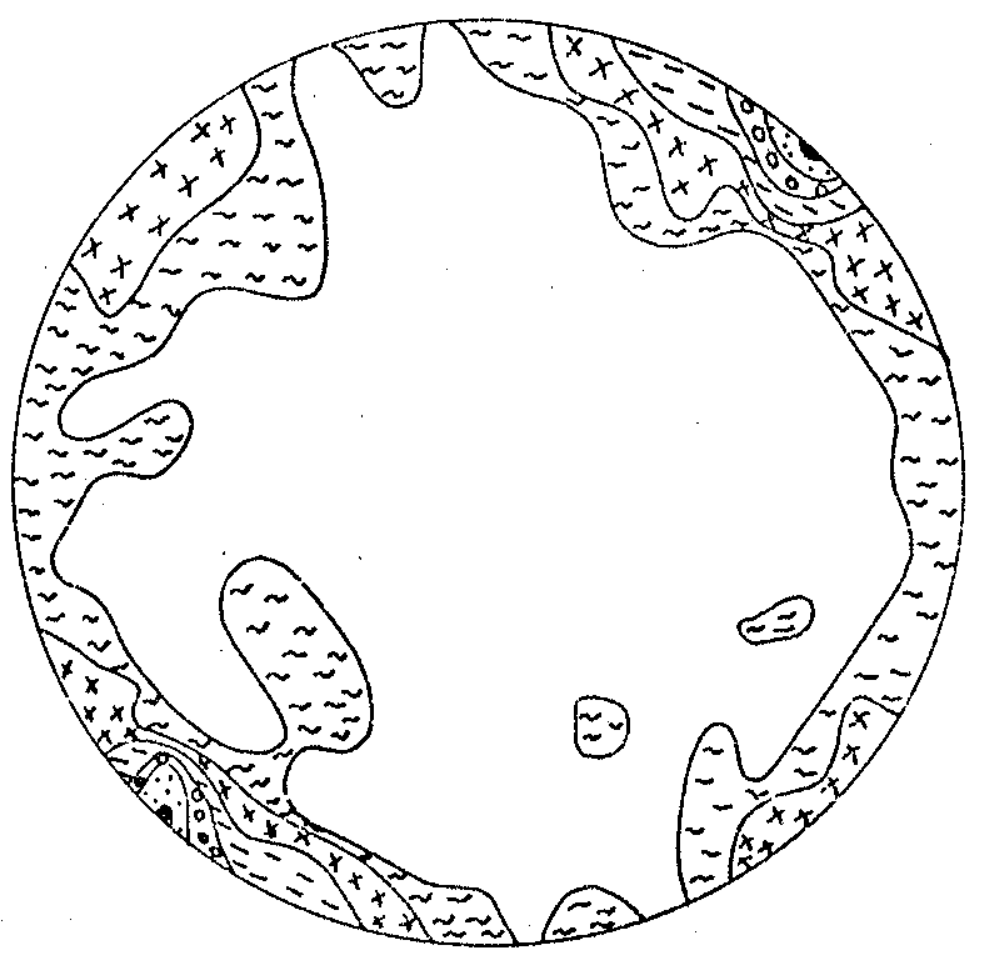

Número de medidas: 775 Máximo de concentracäo: $\mathrm{N} 49^{\circ} \mathrm{W} / \mathrm{Subvertical}$ $\mathrm{N} 53^{\circ} \mathrm{W} /$ Subvertical $\mathrm{N} 44^{\circ} \mathrm{E} /$ Subvertical

\begin{tabular}{|c|c|}
\hline & $0-1 \%$ \\
\hline$\approx \approx$ & $1-3 \%$ \\
\hline 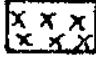 & $3-6 \%$ \\
\hline$E=$ & $6-9 \%$ \\
\hline $\begin{array}{lll}0 & 0 & 0 \\
0 & 0 & 0 \\
\end{array}$ & $s-12 \%$ \\
\hline$\therefore \therefore$ & $12-15 \%$ \\
\hline & - \\
\hline
\end{tabular}

Figura 08 - Diagrama de frequencia dos polos das atirudes de fraturas (Proj. Hem. Inf.) - Atibaia (SP) 


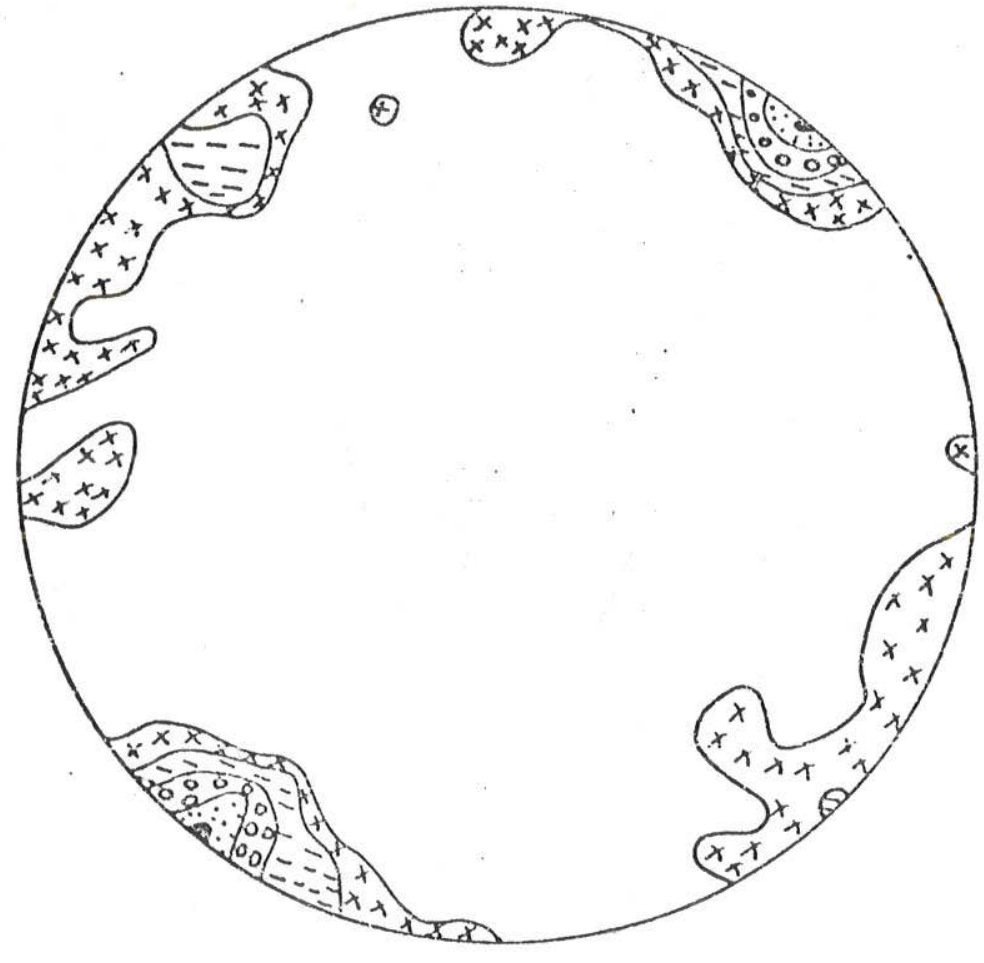

A-Granito Socorro

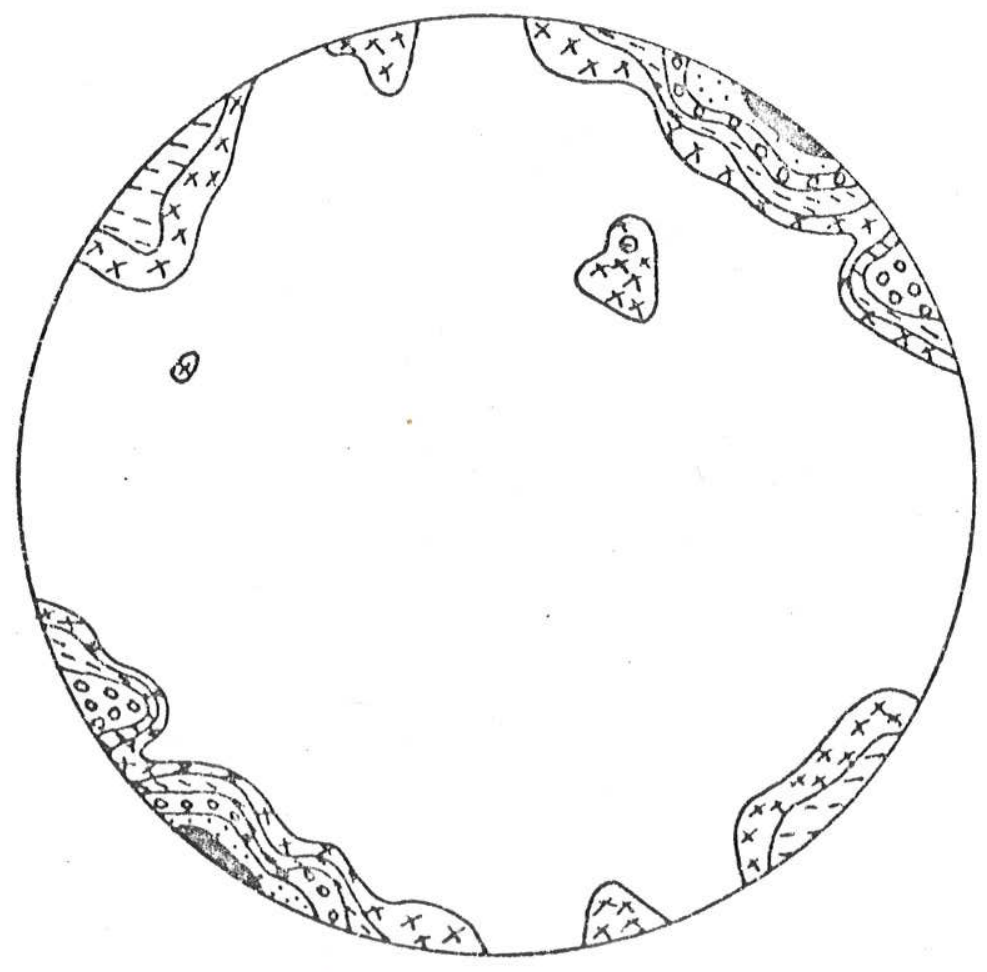

B - Complexo Amparo
Número de medidas: 191

Máximos de concentroção $\mathrm{N} 48^{\circ} \mathrm{W} /$ Subvertical $\mathrm{N} 46^{\circ} \mathrm{W} / 82^{\circ} \mathrm{SW}$
Número de medidos: 564

Móximos de concentraço N30 $30^{\circ} \mathrm{W} /$ Subvertical $\mathrm{N} 55^{\circ} \mathrm{W} / \mathrm{Subyertical}$

Figura 09 - Diagrama de frequëncia dos pollos das atifudes de fraturas (Proj. Hem. Inf.) - Atibaia (SP). 
A existência de feições de relevo mais elevadas a oeste, adjacentes ao traco da falha, pode ser oriunda da. influência desta tectônica e neste caso, as estrias de rejeito obliquo seriam mais jovens. Assim, esta falha se formou em carāter de transcorrência e foi, posteriormente, reativada como falha normal.

Outros falhamentos importantes ocorrem a este-sudeste da ārea, com direcōes preferenciais entre N200 a 400E, com mergulhos de alto a mëdio grau, tanto para NW quanto para SE. As zonas milonitizadas apresentam foliação cataclástica de N15o a $30 \Omega \mathrm{E} / 500$ a $700 \mathrm{SE}$ e as estrias possuem caimento subhorizontal, indicando transcorrência. Porém, são encontradas escarpas de falhas alinhadas com relevo mais alto no bloco ocidental, o que pode representar uma reativação com caracteristicas de falhas normais.

Estes falhamentos normais teriam aproveitado antigos planos de fraqueza, abatendo blocos como um 'graben'' de pequeno. porte.

Outro conjunto de falhas importante ocorre controlando - curso do rio Atibaia, apresentando direção geral E-W na porção oriental e NW-SE na parte ocidental.

\section{3 - Hidrologia de Superficie}

A área de estudo faz parte da bacia do rio Piracicaba que juntamente com outras bacias foram estudadas pelo DAEE em 1981, que utilizou um modelo deterministico de simulação hiarológica (MODELO MERO) calibrado com dados de uma série de 30 anos (periodo de 1948 a 1978).

Estas bacias foram dividiaas em sub-bacias. As diferenças entre as mëdias das séries anuais de volumes médios escoados no ano para cada sub-bacia situou-se entre 68 e 158 , 
comprovando os bons resultados obtidos na fase de calibragem do modelo.

A área pesquisada possui partes das sub-bacias Atibaia 1 e Atibaia 2 (Figura 10), predominando a segunda, e o divisor hidrogräfico entre elas é a serra de Atibaia, que possui altitude de 1.420 metros. No contexto geológico, Atibaia 1 drena terrenos gnaissico-migmatiticos com espessos mantos de alteracão, enquanto Atibaia 2 drena litologias graniticas, onde os mantos de alteração são menos espessos.

Resultados do balanço hidrológico são mostrados no quadro 01 sendo estes dados exclusivos para cada sub-bacia, ou seja, não foram levados em consideração os resultados obtidos em àreas à montante.

Com relação aos indices indicadores do regime hidrológico, observa-se que a relação Qt/p é igual a $38 \%$ e isto quer dizer que do volume precipitado sobre cada sub-bacia, $38 \%$ sai. como vazão no ponto de controle fluvial. A relação $Q b / P$ mostra que 13 o da precipitação infiltra, fluindo pelos aquiferos e/ou retornando aos rios sob a forma de vazão de base.

A relação Qb/Qt é da ordem de $34 \%$ e ressalta a boa capacidade de armazenamento d'ägua em sub-sliperficie.

\section{$3.4-H i d r o g e o l o g i a$}

o dominio cristalino é tratado pela hidrogeologia como un tópico à parte $\in$ nele se pode ter dois contextos principais: rochas cristalinas com espessos mantos de alteracão, onde a circulação d'âgua subterrânea ocorre através dos intersticios criados pela ação do intemperısmo e, rochas cristalinas inalteradas, ou com pequeno manto de alteracão, onde o fluxo subterrāneo ocorre predominantemente em fraturas. 

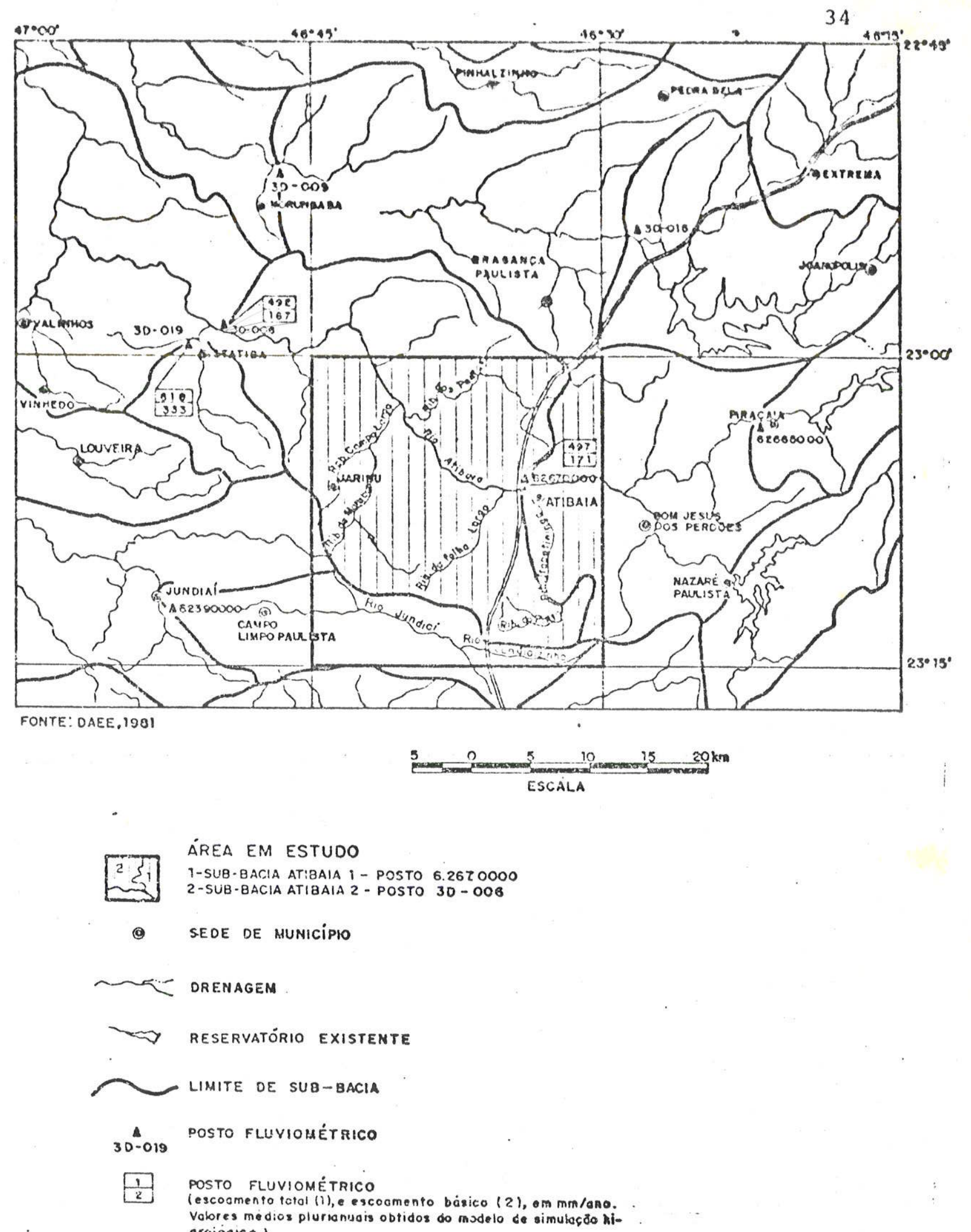

(9) SEDE DE MUNICIPIO

Figura 10-Localizaçāo da área estudada em relaçāo a3 sub-bacics hiarográficas 


\begin{tabular}{|l|l|l|}
\hline \multicolumn{1}{|c|}{ R I O } & \multicolumn{1}{|c|}{ ATiBAIA } & \multicolumn{1}{|c|}{ ATIBAINHA } \\
\hline Posto fluviométrico (prefixo) & Itatiba (3D-006) & Atiba1a (62670000) \\
Area de drenagem $\left(\mathrm{km}^{2}\right)$ & 775 & 420 \\
Prectpitação (P) - mm/ano & 1.296 & 1.319 \\
Evaporação real - mm/ano & 802,7 & 821,2 \\
Escoamento total (Qt) - mm/ano & 492 & 497 \\
Escoamento bäsico (Qb)-mm/ano & 167 & 171 \\
Qc/P (\%) & 37,96 & 37,68 \\
Qb/P (\%) & 12,88 & 12,96 \\
Qb/Qt (\%) & 33,94 & 34,40 \\
\hline
\end{tabular}

FONTE: DAEE, 1981.

QUADRO 01 - MEDIAS MULTI-ANUAIS DO BALANÇO HIDRICO 
O primeiro caso representa aproximadamente 80 \& da área precambriana brasileira (Figura 11) e nele está inserida a área em estudo.

Neste tópico será feita uma caracterização das zonas aquiferas definidas, tendo por base o cadastro dos pocos tubulares e escavados e os aspectos geológicos, geomorfológicos, estruturais e hidrogeolögicos observados.

\subsection{1 - Caracterização das Zonas Aquiferas}

\subsubsection{1 - Manto de Intemperismo}

Neste trabalho, o têrmo manto de intemperismo, ou de alteração, è utilizado para representar a zona de rochas alteradas pelo intemperismo fisico-quimico. A espessura considerada desta zona vai desđe o solo até o contato entre a rocha aiterada, que mantém estrutura's reliquiares, com a rocha sã.

Na perfuração de poços tubulares, o manto de intemperismo, tem que ser revestido para que não ocorra desmoronamento das paredes do furo. Desta forma, a extensão do revestimento foi utilizada como criterio para se estimar as espessuras do manto de alteração, devendo ser ressaltado que, além do revestimento utilizado para estabilizar as paredes do poço, alguns metros $(1,0$ a $2,0 \mathrm{~m})$ penetram na rocha sã para que a tubulação seja fixada (processo denominado de cravação).

A integracão dos fatores litológico, fraturamento e drenagem é de fundamental importância no desenvolvimento do perfil de alteração. 


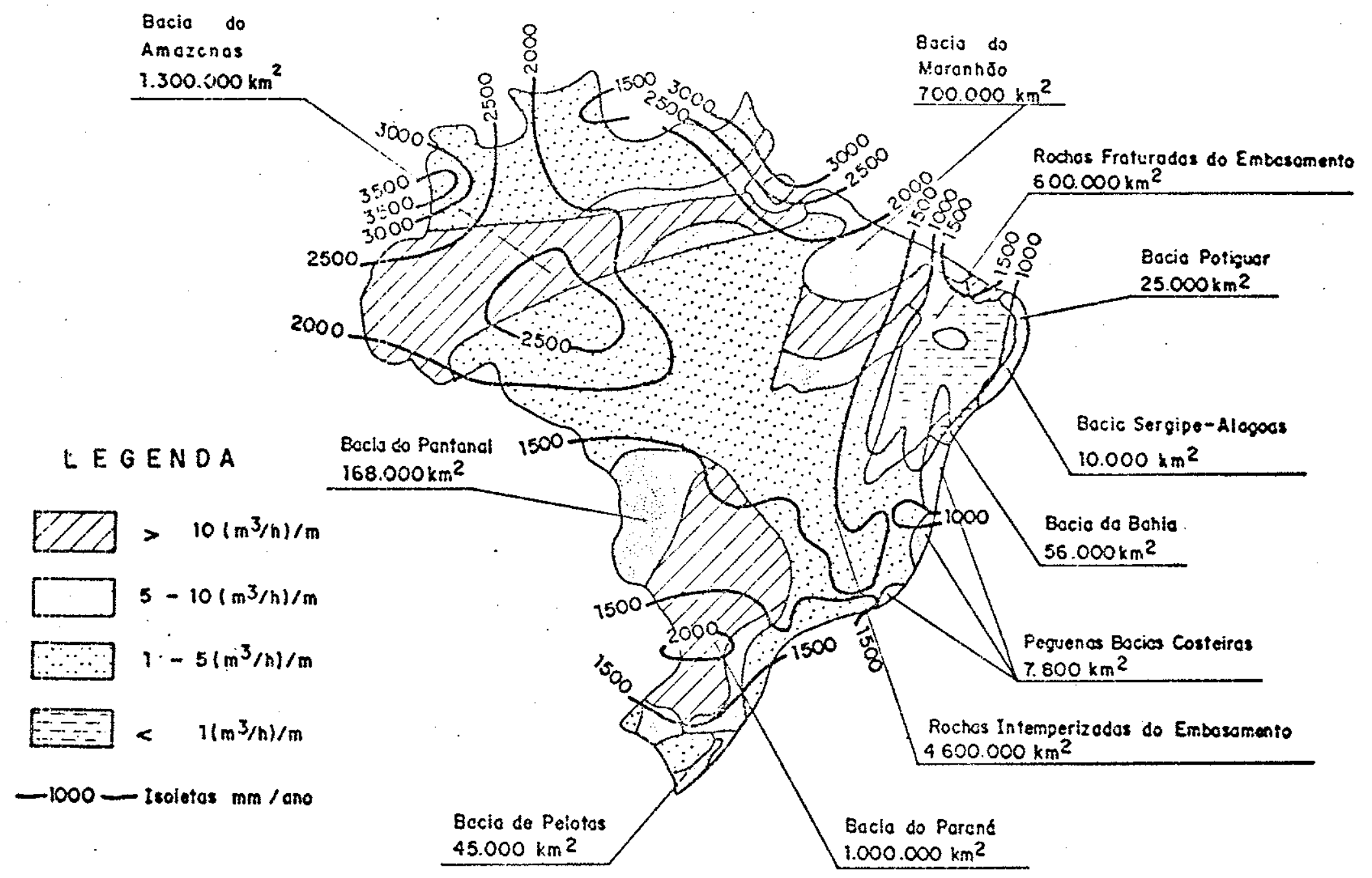

Figura 11 - Potenciais de Éguas Subterrōneas no Brasil (REBOUGAS, 1988) 
A maior espessura do manto de intemperismo encontrada na região foi de 59,0 metros (Figura 12$)$ e 0 intervalo que predomina situa-se entre 20,0 e 40,0 metros $(688)$, sendo que as menores estão associadas as cotas mais baixas, enquanto que as maiores encontram-se nas mais altas cotas e/ou em zonas fraturadas.

A espessura saturada è, predominantemente, inferior a 10,0 metros (Figura 13).

As maiores espessuras do manto de intemperismo estão no dominio do Complexo Amparo (Foto 04). As rochas desta unidade possuem uma composição mineralógica com mais de 408 de anfibólios e micas que alteram-se com muita facilidade em comparação com quartzo e feidspatos, minerais preponderantes nos macicos graniticos. Ainda, a existência de uma densa rede de drenagem, muitas vezes congruente às fraturas ou falhas, associada as caracteristicas estruturais dos litótipos (xistosidade. bandamento composicional, etc) faz com que estas litologias sofram uma ação intempérica muito mais rápida resultando, consequentemente, em maiores espessuras do manto de alteração.

Exemplos deste fato são encontrados nos perfis Iitológicos dos pocos tubulares de números $59,36,23,10$ e 46 que apresentam espessuras de rochas alteradas de $52,50,49,42$ e 41 metros, respectivamente. O perfil de alteração existente na área pode ser sumarizado da seguinte forma:

a) Zona superficial formada por material argiloso a siltoaxgiloso, onde o processo pedogenético já alcançou seu desenvolvimento máximo. Possui espessuras que variam de 1,0 a 5,0 metros;

b) material argilo-siltoso a areno-argiloso, localmente silto-argiloso, onde as estruturas da rocha matriz são pouco preservadas. 


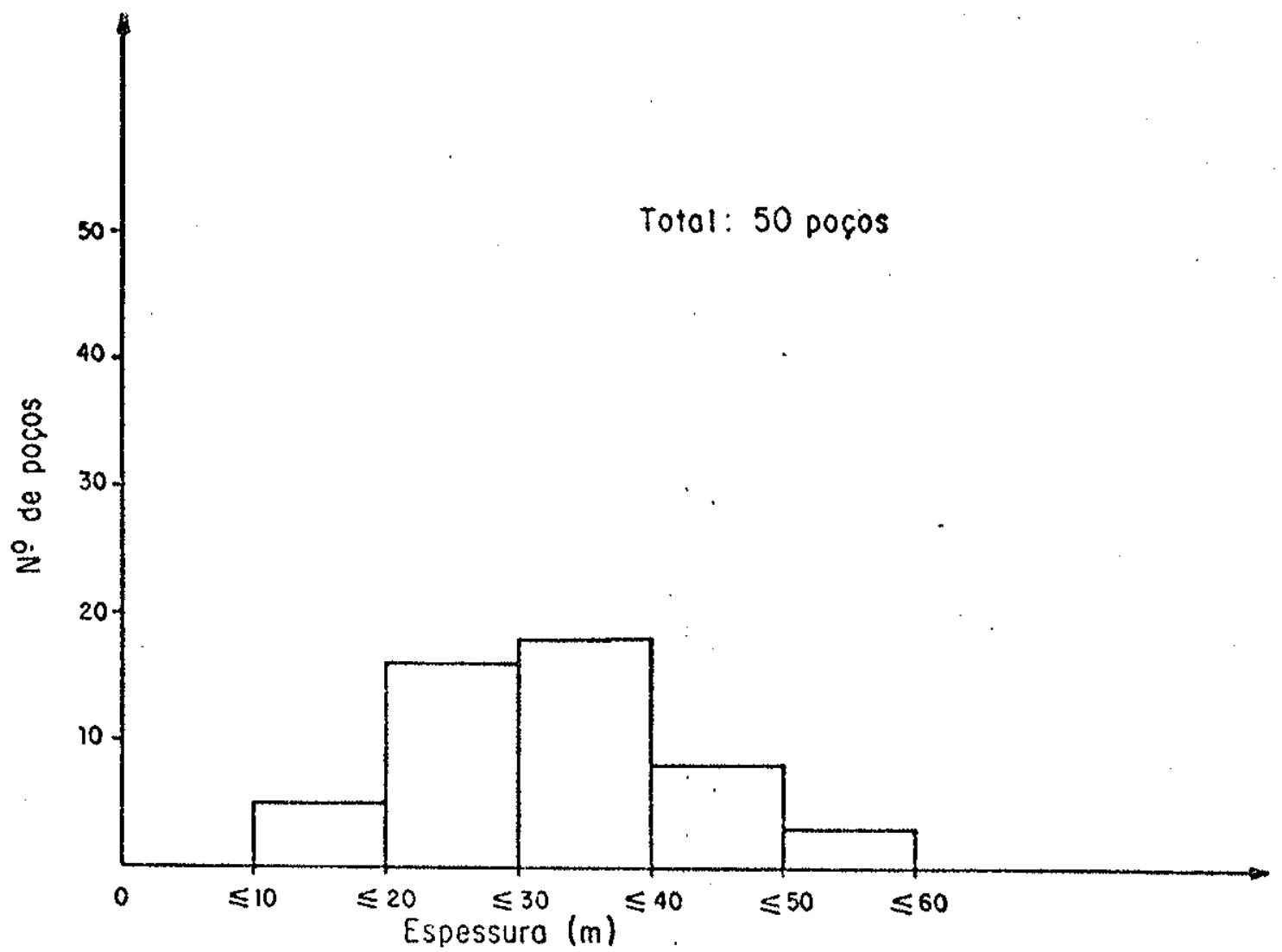

Figura 12 - Distribuiçāo de frequēncia das espessurcs do manto de alterogäo 


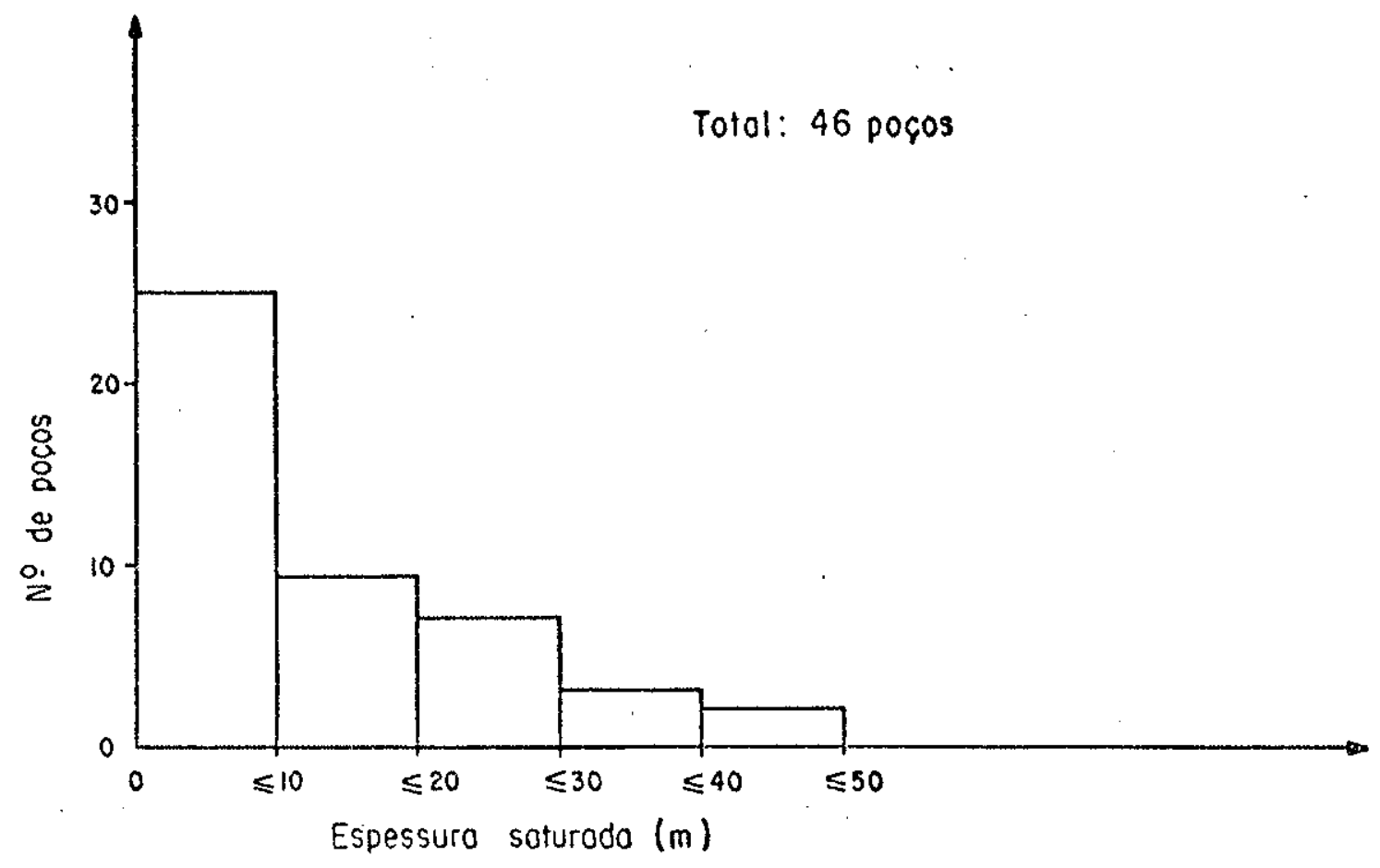

Figura 13 - Distribuição de frequência das espessuras saiuradas 


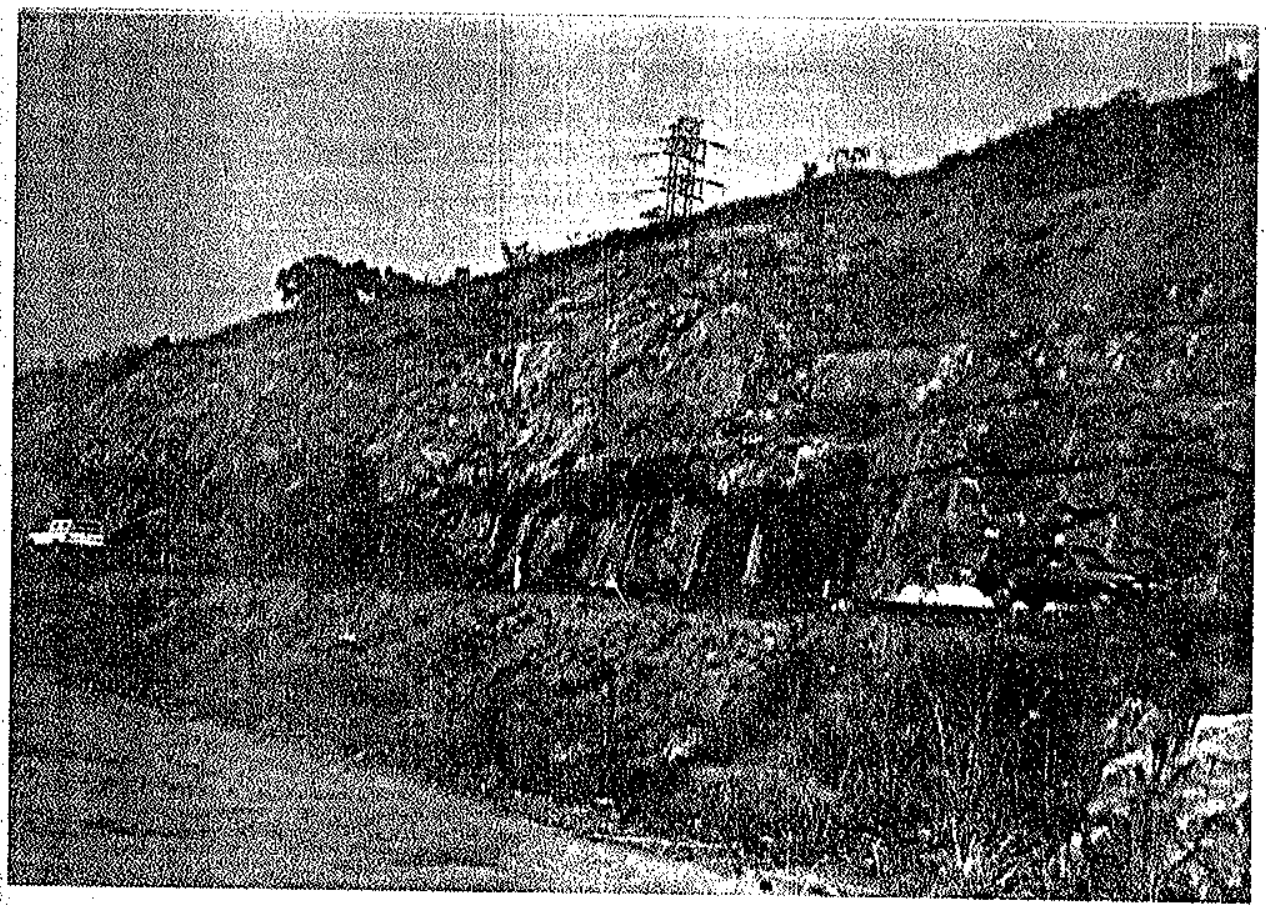

Foro 04 - Perfil de alteracão do Complexo Amparo (espessura média de $20 \mathrm{~m}$ ).

LOCAL : - Rodovia Fernão Dias (BR-381), trecho Atibaia - Braganca Paulista (SP). 
- Complexo Amparo apresenta cores avermelhadas, arroxeadas, esbranquicadas e amareladas como consequência da maior ou menor concentração de mä́ficos. os xistos, anfibolitos e metabásicas, sempre alteradas, apresentam tonalidades ocres ou marrons; em estado de lixiviação muito intenso, a capa de alteração exibe cores mais amareladas, tipicas de bauxitas.

As espessuras variam de 5,0 a 20,0 metros, a condutividade hidrāulica é baixa $\left(10^{-4}\right.$ a $\left.10^{-5} \mathrm{~cm} / \mathrm{s}\right)$ e a porosidade eficaz é muito pequena $(0,1$ a $2 \%)$.

c) material friável formado por cristais desagregados, parcialmente alterados, e fragmentos de rochas em estado de alteração, porēm mantendo as características da rocha matriz.

As espessuras situam-se entre 5,0 e 30,0 metros, a condutividade hidráulica é de moderada a alta $\left(10^{-3}\right.$ a $10^{-2}$ $\mathrm{cm} / \mathrm{s})$ e a porosidade eficaz varia de 2 a $58 ;$

d) rochas fraturadas, pouco alteradas, conservando toda a estrutura da rocha sã. A espessura desta zona é de poucos metros e o fluxo é realizâo essencialmente através das fraturas e, consequentemente, a condutividade hidráulica é alta $\left(10^{-1}\right.$ a $\left.10^{-2} \mathrm{~cm} / \mathrm{s}\right)$, podendo variar localmente, e a porosidade eficaz varia de 0,5 a 38 .

o intervalo de predomínio da profundidade do nivel estático nas cacimbas é de 0,4 a 9,0 metros (818), como mostra a figura 14.b. Os valores acima de 9,0 metros mostram que os pocos estão situados em niveis topograficamente mais altos. 
Foram instalados trēs piezômetros multiniveis objetivando observar a relação entre o manto de intemperismo e o meio fraturado (item 2.5, página 09). O critério para verificar se existia transferência das águas do manto para o fraturado, consistiu em se bombear o poço tubular e monitorar o nível estático dele e do piezômetro.

A tabela 02 mostra as caracteristicas dos sistemas observados.

\begin{tabular}{|c|c|c|c|c|c|c|c|}
\hline \multicolumn{7}{|c|}{ POÇO TUBULAR } & \multirow{2}{*}{$\begin{array}{l}\text { prof. } \\
\text { piez. } \\
\text { (m) }\end{array}$} \\
\hline n.ordem & $\begin{array}{l}\text { prof. } \\
(\mathrm{m})\end{array}$ & $\begin{array}{l}\text { rev. } \\
(\mathrm{m})\end{array}$ & $\begin{array}{c}Q \\
\left(m^{3} / h\right)\end{array}$ & $\begin{array}{l}N \cdot E \text {. } \\
(\mathrm{m})\end{array}$ & $\begin{array}{l}N . D . \\
(m)\end{array}$ & $\begin{array}{l}\text { cap.esp. } \\
\left(\mathrm{m}^{3} / \mathrm{h}\right) / \mathrm{m}\end{array}$ & \\
\hline 4 & 80 & 20 & 3,3 & 15 & 35 & 0,165 & 30 \\
\hline 19 & 132 & 20 & 18 & $+0,5$ & 63 & 0,285 & 11 \\
\hline 22 & 150 & 21 & 1,6 & 7 & 132 & 0,012 & 17 \\
\hline
\end{tabular}

- prof. = profundidade

- rev. = revestimento

-Q. $\quad=\operatorname{vazão}$

- N.E. = nivel estático

- N.D. = nível dinâmico

- cap.esp. = capacidade especifica

- prof.piez.= profundidade do piezômetro multinivel que monitora - poco tubular.

TABELA 02 - CARACTERISTICAS DOS POCOS TUBUIAARES MONTTORADOS E DOS PIEZOMETROS MULTINIVEXS 


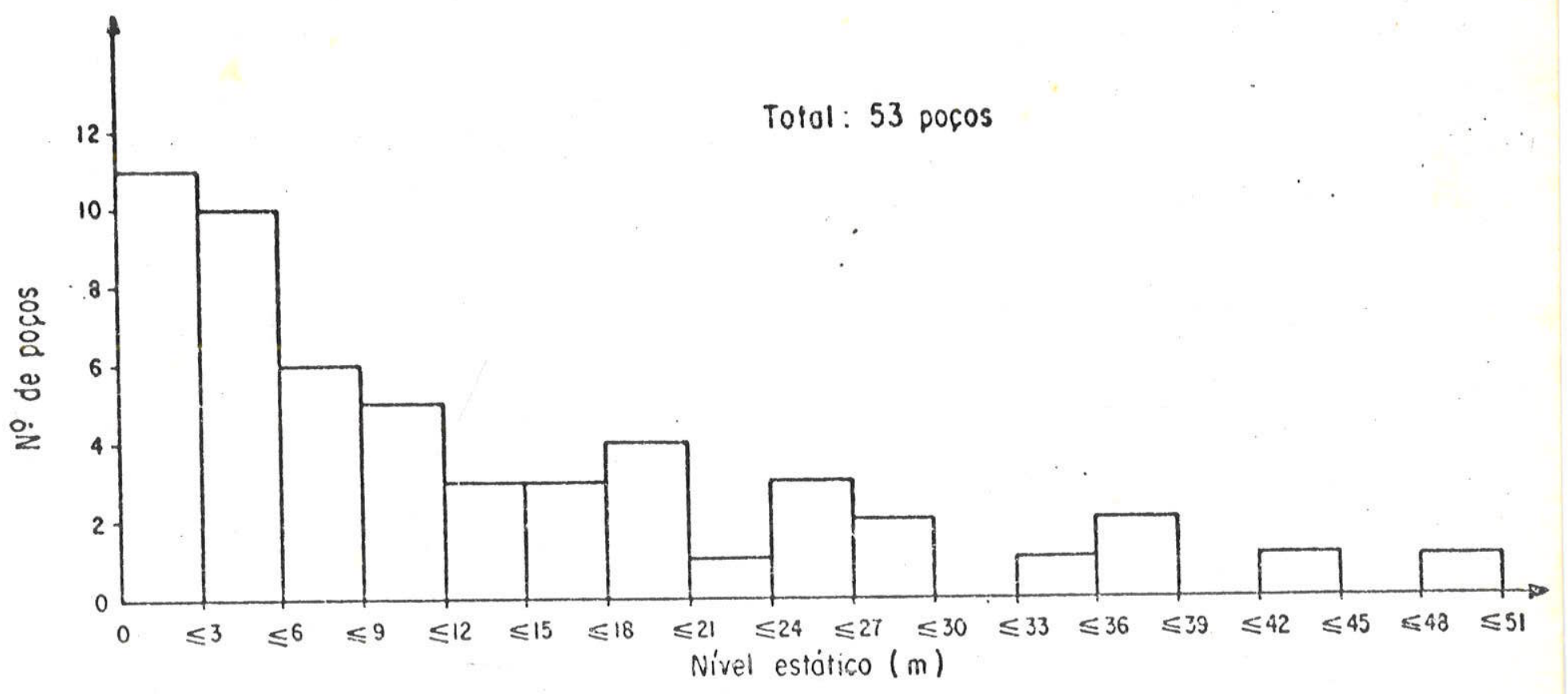

a) poços tubulares

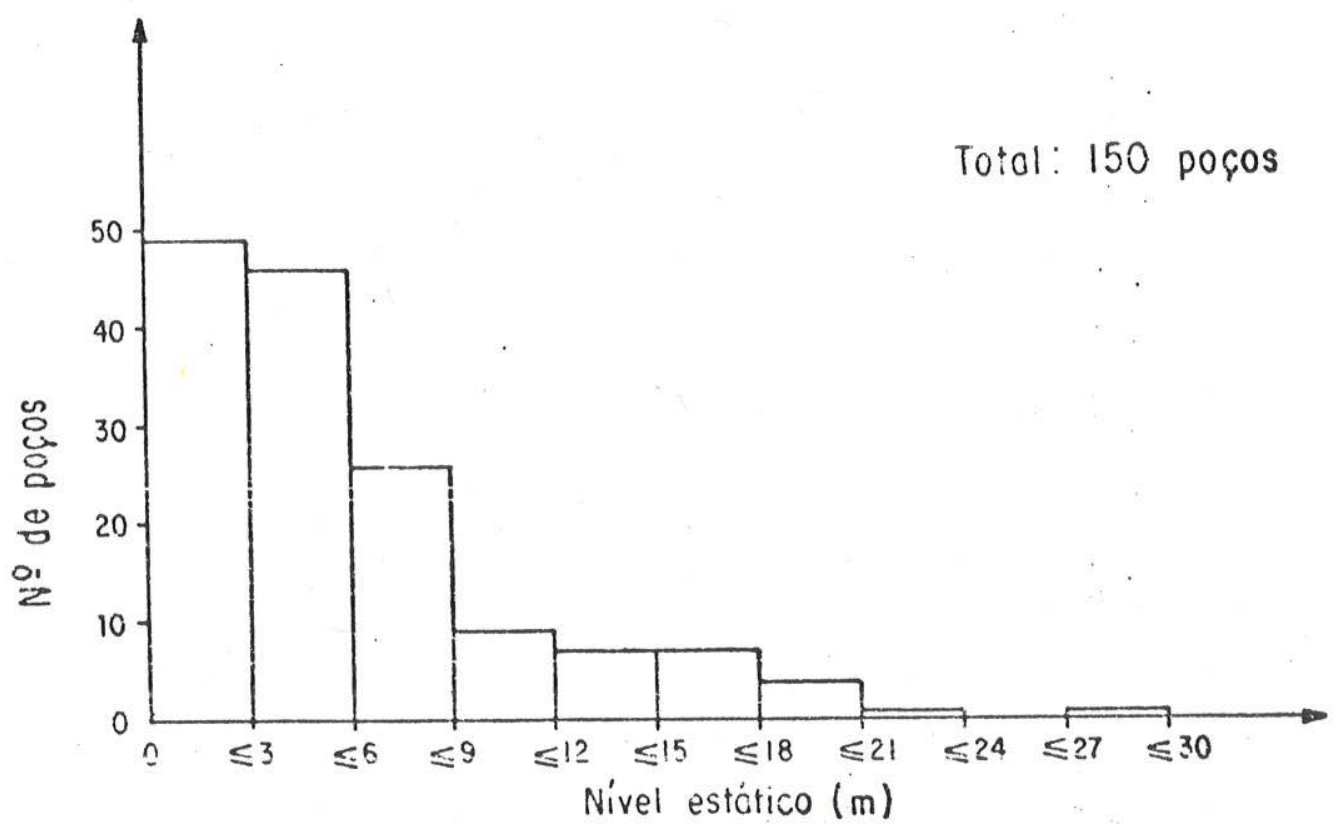

b) pocos escavados

Figura 14 - Distribuição de frequēncia dos níveis d'águo dos poços 
O manto de intemperismo é totalmente revestido e, desta forma, aparentemente a ägua explorada pelos pocos tubulares provëm exclusivamente do meio fxaturado, sendo este raciocinio adotado por todos os perfuradores de poços da região. Porém, observou-se que os niveis estáticos dos piezōmetros 1 e 2 (monitorando os pocos 4 e 19, respectivamente) sofrem rebaixamentos idênticos aos dos poços monitorados, comprovanao a transferência das águas do manto de intemperismo para o meio fraturado.

No piezômetro No 3 (monitorando o poço Ne 22) não ocorreu este fato, o que indica que a água ali explorada provém de área de recarga mais distante, através de fluxo em fraturas.

Os dados da Tabela 01 (página 18) mostram que para o manto de intemperismo onde foram instalados os piezōmetros 1 e 2 , - ültimo nivel alterado (regolito silto-arenoso a arenoso, em contato com a rocha sã) é o que mais contribui em termos de transferência de água subterrânea para o meio fraturado, haja vista que nos dois piezômetros o rebaixamento médio do nivel d'água foi de 2,76 metros, constatando maior condutividade hidráulica. Nos outros niveis aiterados o rebaixamento médio oscila entre 0,16 e 1,45 metros.

Três testes de vazão com duração de 4 horas/poço foram realizacios em cacimbas com lâmina d'ägua da ordem de 5,0 metros. A vazão média foi de $0,9 \mathrm{~m}^{3} / \mathrm{h}$ e o rebaixamento médio de 4,0 metros, o que reflete uma capacidade especifica mëdia de $0,225\left(\mathrm{~m}^{3} / \mathrm{h}\right) / \mathrm{m}$. 


\subsubsection{2 - Meio Fraturado}

Este meio é considerado como um dominio hidrogeológico heterogêneo e anisotrōpico, onde o fluxo ocorre somente nas fraturas, e os seus parâmetros hidrodinâmicos estão estreitamente vinculados a intensidade, abertura e interconeç̧ão da rede, de fraturas.

- intervalo de predomínio da profundidade dos niveis d'ägua está entre 0 e 9,0 metros (50\%) como mostra a figura 14.a. Relacionandoro com o encontrado no manto de intemperismo $(0,4$ a 9,0 metros $(818))$, observa-se que existe uma estreita correlạ̃a que reflete, mais uma vez, a interação entre os dois meios aquiferos, com transferēncia das águas do manto para o fraturado.

As vazões dos poços tubulares são, no geral, abaixo de $10 \mathrm{~m}^{3} / \mathrm{h}(908)$ e destas, o intervalo de 0,3 a $5 \mathrm{~m}^{3} / \mathrm{h}$ detém $55 \%$ (Figura 15). Não existe critério definido entre vazão e profundidade do poço como mostra a figura 16, e normalmente os poços mais profundos estão locados em áreas de recarga (divisores hidrográficos) apresentando vazões inferiores a $2 \mathrm{~m}^{3} / \mathrm{h}$.

Nas fichas técnicas dos poços foram encontrađas referências a entradas d'āgua (anotadas como fraturas) a profundidades que variam de 24 a 220 metros, com o intervalo de 24 a 102 metros predominando com 628 (Figura 17) e, se considerarmos até 154 metros, tem-se um predominio de 85,78 . porém, deve ser lembrado que nem sempre o maior nümero de fraturas implica, necessariamente, em maior vazão, já que esta no meio fraturado se relaciona com fraturas abertas, interconectadas e fonte de recarga. 


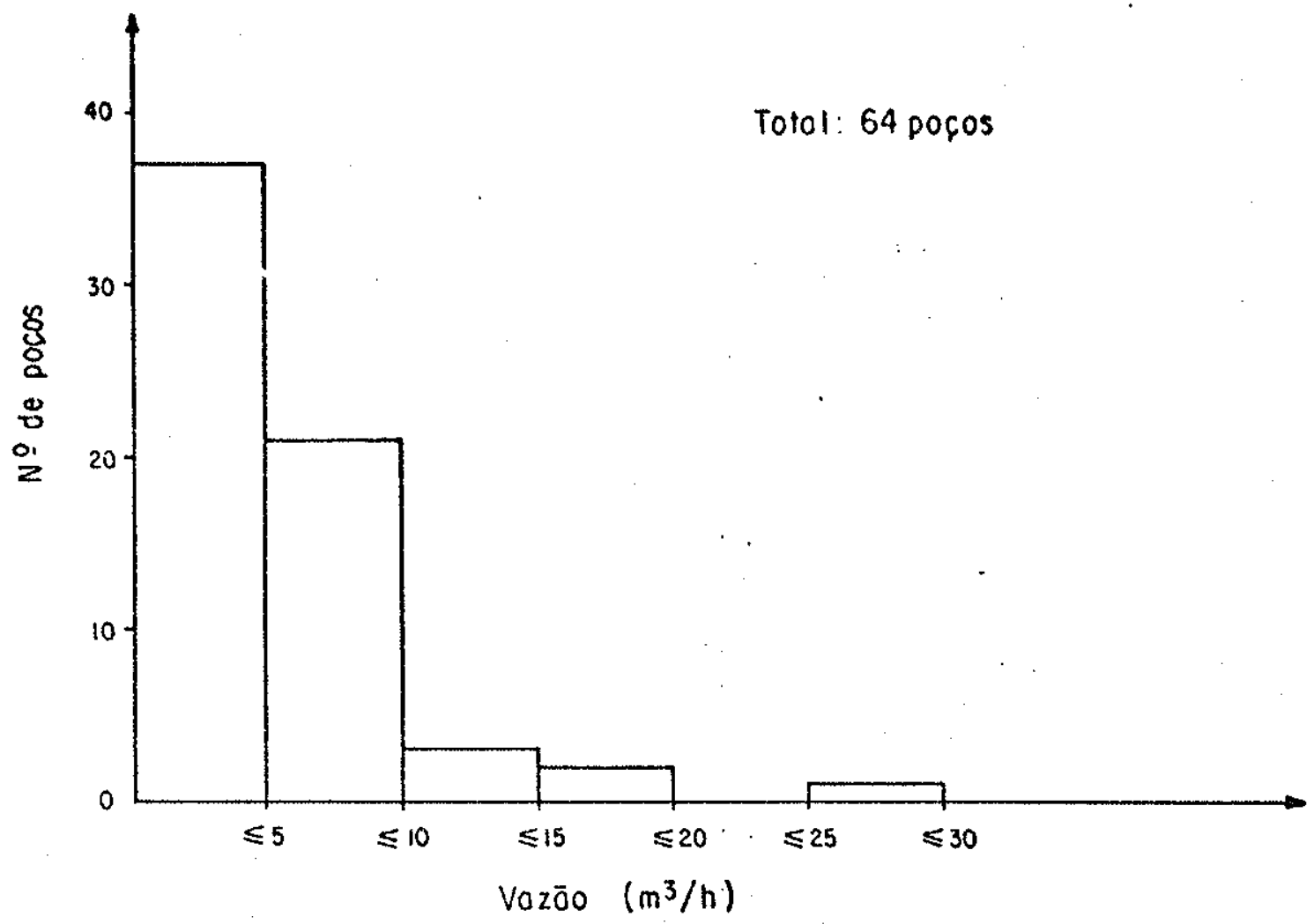

Figura 15 - Distribuiçōo de frequēncia das vazōes dos poços tubulares 


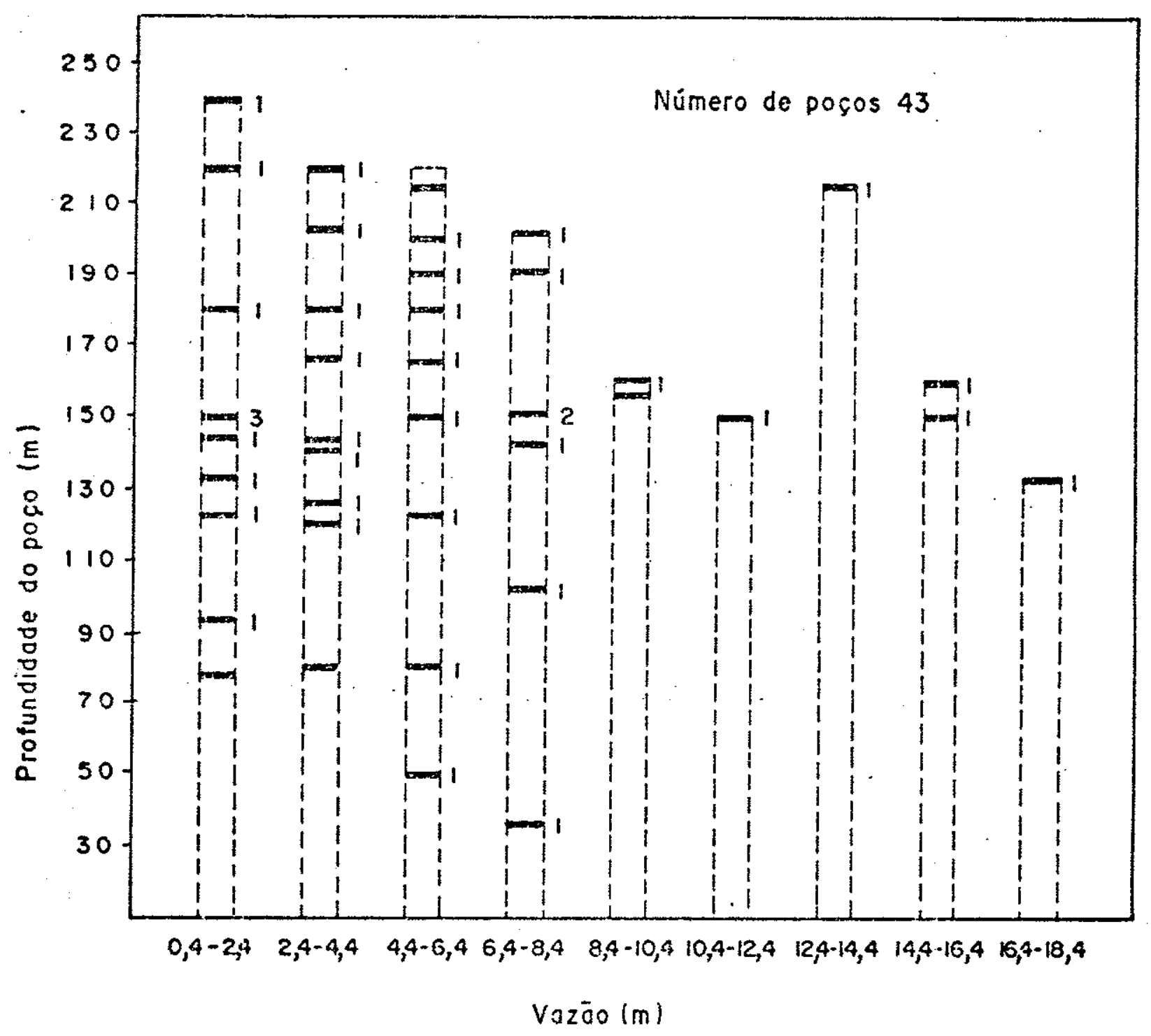

(2) Número de poços existentes

Figura 16 - Reloçäo entre vazäo e profundidade dos pogos fubulares - Atibaia (SP) 


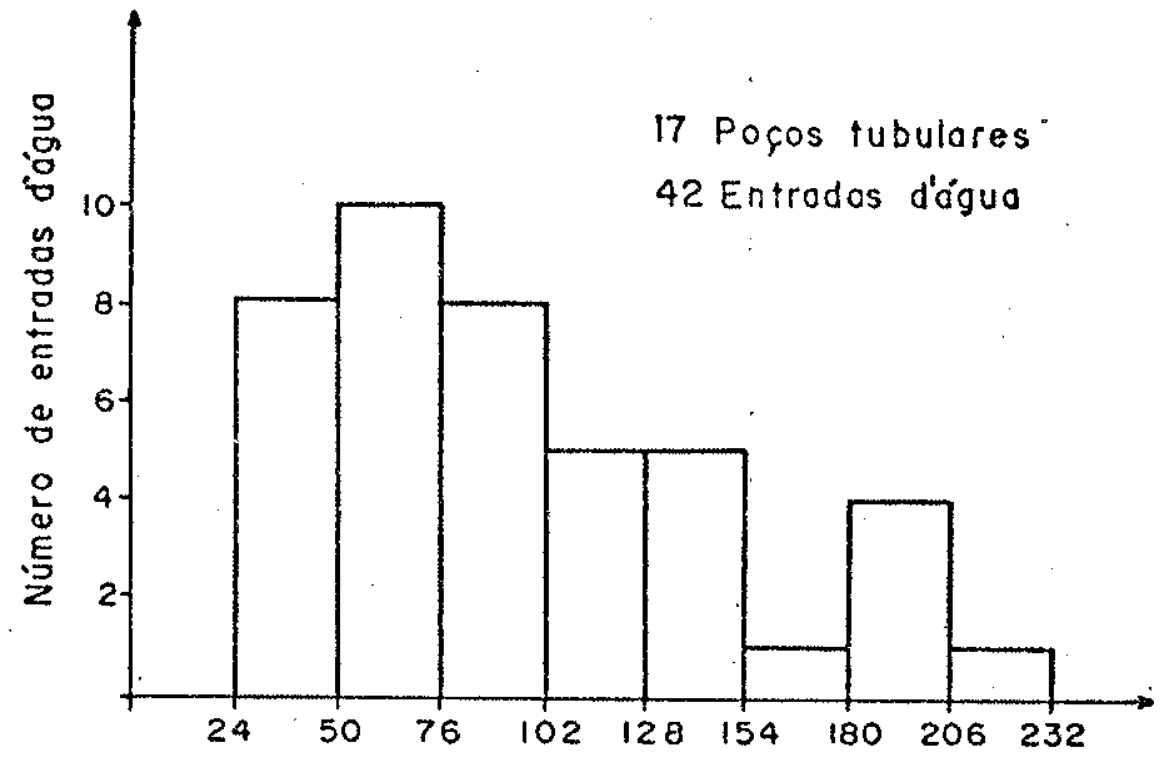

Profundidade dos entrodas d'ćgua $(m)$

Figura 17 - Frequēncia das profundidades dos entradas d'água na regiāo de Atibaia - SP 
A figura 18 mostra que 78,68 das entradas d'águas pertencem a pocos perfurados em altitudes menores ou iguais a 800 metros, área considerada como de descarga. Se o poço está locado em área de recarga, mesmo tendo um número significante de fraturas, sua vazão seră muito inferior comparativamente a de outro poco com as mesmas caracteristicas construtivas e nümero de fraturas, posicionado em área de descarga.

A capacidade específica é uma medida da eficiência da obra de captação e ela foi calculada para 44 poços tubulares da área em estudo. Os valores foram plotados em papel probabilistico log-normal (Figura 19) e apresentaram mediana de $6 \times 10^{-2}\left(\mathrm{~m}^{3} / \mathrm{h}\right) / \mathrm{m}$ com minimo e máximo de $2 \times 10^{-3}$ e $0,67\left(\mathrm{~m}^{3} / \mathrm{h}\right) / \mathrm{m}$, respectivamente.

O DAEE (1981) analisou dados de 515 poços tubulares da 5a. Região Administrativa e obteve valores para a capacidade especifica entre $2,5 \times 10^{-3}$ e $3,6\left(\mathrm{~m}^{3} / \mathrm{h}\right) / \mathrm{m}$ com mediana de $6 \times 10^{-2}$ $\left(\mathrm{m}^{3} / \mathrm{h}\right) / \mathrm{m}$ e valores mais frequentes entre $2 \times 10^{-2}$ e 0,36 $\left(\mathrm{m}^{3} / \mathrm{h}\right) / \mathrm{m}$. BERTACHINI (1987) estudou a região de Jundiai, adjacente a área ora estudada, e determinou a capacidade especifica para 189 poços, que oscilou entre 3,6 x $10^{-3}$ a 3,6 $\left(\mathrm{m}^{3} / \mathrm{h}\right) / \mathrm{m}$ com mediana de $0,10\left(\mathrm{~m}^{3} / \mathrm{h}\right) / \mathrm{m}$ e valores mais frequentes entre $2 \times 10^{-2}$ e $0,54\left(\mathrm{~m}^{3} / \mathrm{h}\right) / \mathrm{m}$. Ressalta-se que os pocos analisados por BERTACHINI (op. cit.) estão inclusos nos estudados pelo DAEE (op. cit.).

Porēm, estes resultados devem ser utilizados com precaução, pois existindo, localmente, transferência das àguas do manto de intemperismo para o meio fraturado, as capacidades especificas refletirão caracteristicas de um meio aquifero com dupla porosidade, e não unicamente do fraturado. 


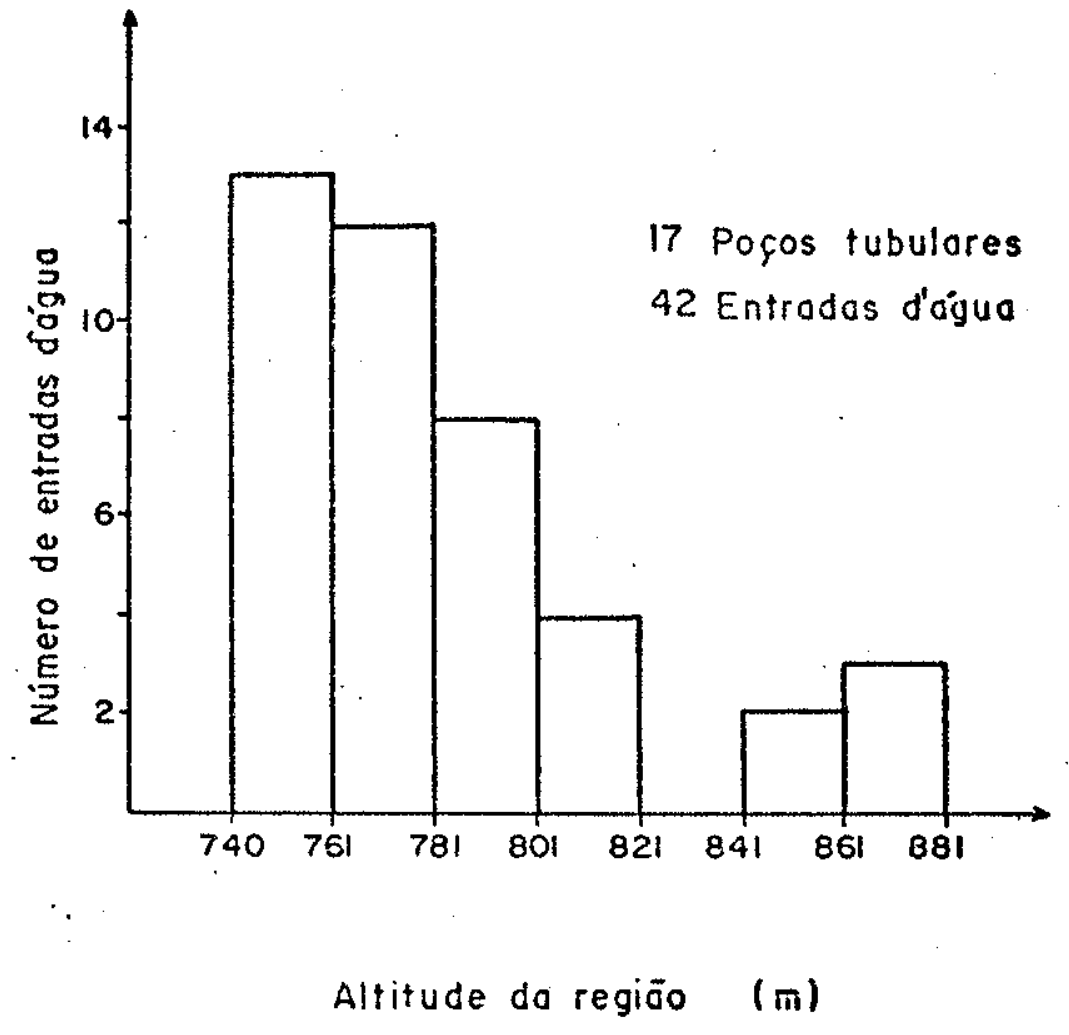

Figura 18 - Relaçāo entre altitude da regiāo e entrados d'agua - Atibaia (SP) 


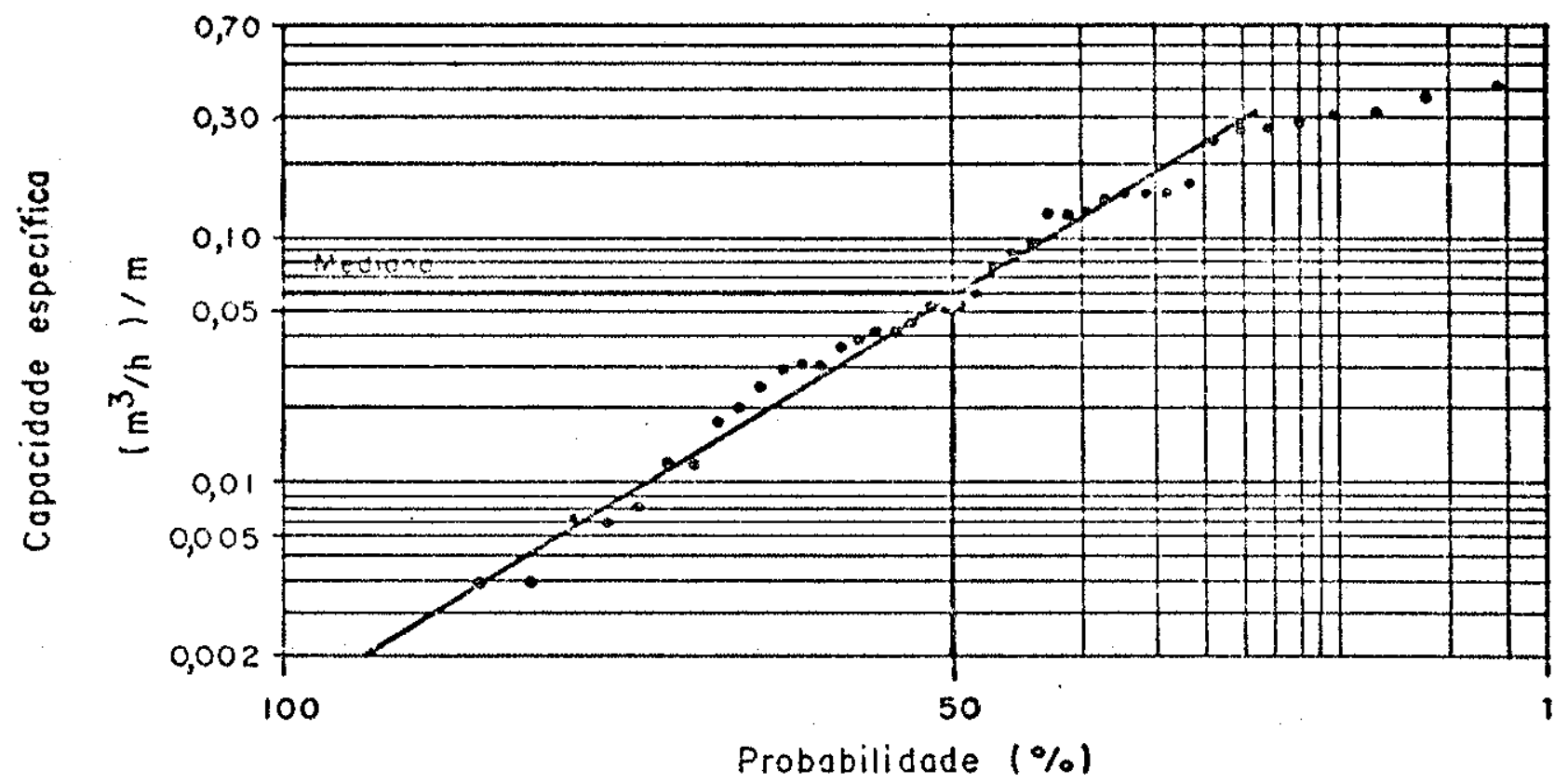

Figura 19 - Probabilidade logarítimo normal da capacidade específica dos pocos tubulares da regiäo de Atibaia - SP 


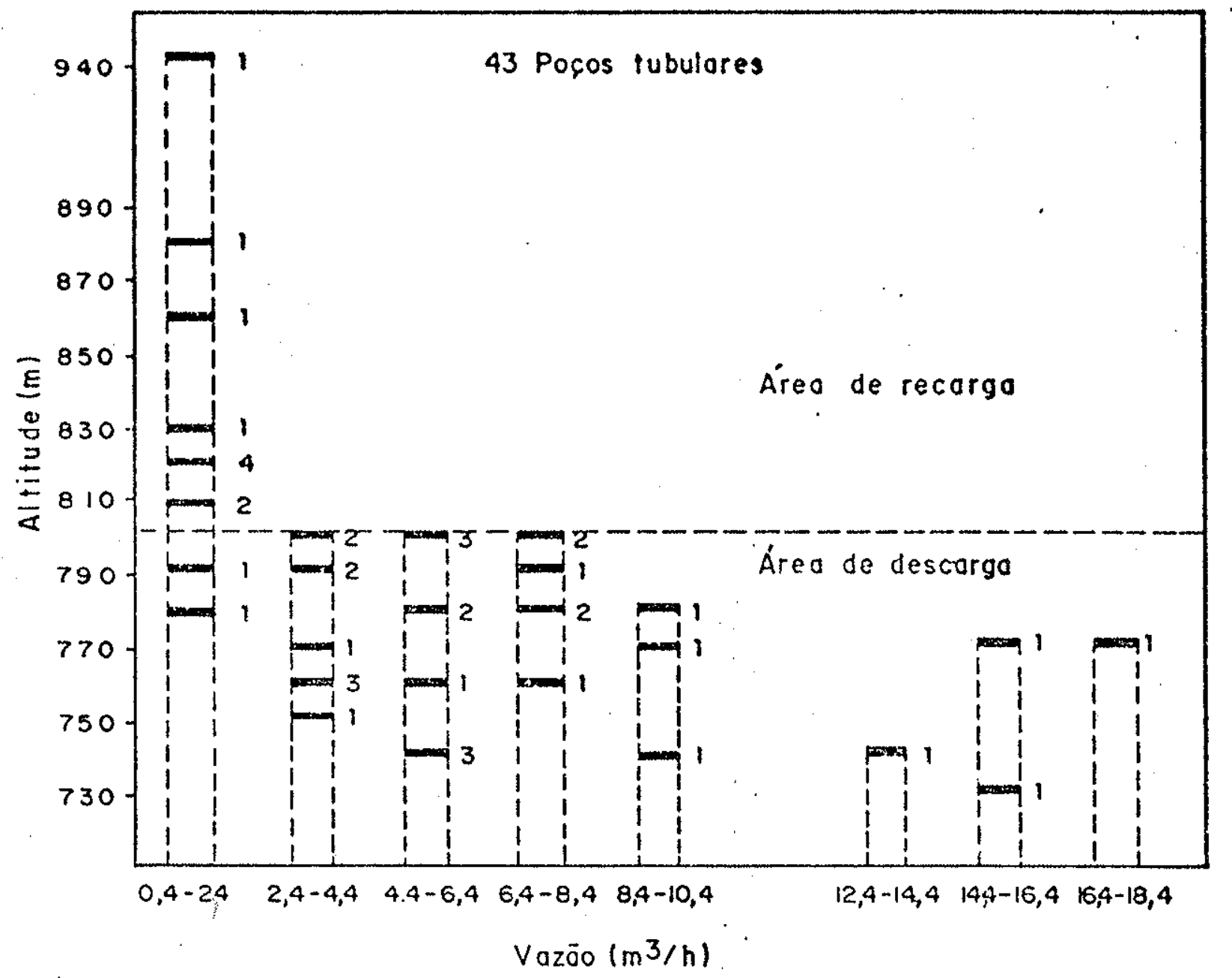

(2) Número de poços existentes

Figura 20 - Relação entre vazōo do popo e cltitude do local onde foi periurodo - Regiäo de Atiboia (SP). 
A transmissividade obtida por BERTACHINI (op. cit.) oscilou entre $1,2 \times 10^{-6}$ a $1,4 \times 10^{-3} \mathrm{~m}^{2} / \mathrm{s}$.

Apesar da densidade de fraturas ser um aspecto relevante à locação do poço, ela não assegura melhores vazões e sim, locais mais propicios, comparativamente a outros, para a perfuração. BERTACHINI (op. cit.) diz que "...a maior densidade de frequência de lineamentos de fraturas por unidade de área, não implica no aumento da condutividade hidrāulica das zonas fraturadas.." e isto reflete o fato de que além da existência de fraturas, estas devem ser abertas para que possa ocorrer fluxo subterrâneo.

Analisando a locação dos poços em função dos condicionantes morfológicos, observa-se que $80,5 z$ deles estão locados em altitudes menores ou iguais a 810 metros (Figura 20 ). Porém, a locação na região não obedece critério morfológico e está associada unicamente ao local da demanda, haja vista se ter pocos pexfurados em altitude de até 940 metros, área de divisor hidrográfico. A anälise de 10 poços perfurados em divisores d'água mostra que a vazão oscila entre $0,25 \mathrm{e} 1,6 \mathrm{~m}^{3} / \mathrm{h}$, com média de $0,7 \mathrm{~m}^{3} / \mathrm{h}$, e a capacidade especifica está no intervalo de 2,35 $\times 10^{-3}$ a $0,20\left(\mathrm{~m}^{3} / \mathrm{h}\right) / \mathrm{m}$ com média de $8,51 \times 10^{-3}\left(\mathrm{~m}^{3} / \mathrm{h}\right) / \mathrm{m}$.

A unidade litológica mais perfurada é o Complexo Amparo, detendo 788 dos poços. Este fato está associado a ocupação popuiacional, pois esta uniaade ocupa uma área de $325,5 \mathrm{~km}^{2}(558)$ e possui altitudes normalmente inferiores a 810 metros.

Os condicionantes estruturais constituem um dos aspectos de locação de pocos ent terrenos cristalinos mais discutidos na hidrogeologia. Trabalhos como os de SIQUEIRA 
(1963) e COSTA $(1965,1986,1987)$ na região Nordeste e de SILVÁ (1984) e BERTACHINI (1987) no sudeste, enfocam a geologia estrutural como um instrumento ütil para esta finalidade. BERTACHINI (op. cit.) mostra que para a região de Jundiai, os pocos situados nos lineamentos foto-interpretados de maior extensão e que apresentam forte evidência de fratura, são os que possuem os maiores valores de capacidade especifica.

Na região de Atibaia, a anālise de dados relativos a 11 poços efetivamente, locados sobre lineamentos de fraturas, mostra que eles possuem vazao média de $7,9 \mathrm{~m}^{3} / \mathrm{h}$, com minima de $3,2 \mathrm{~m}^{3} / \mathrm{h}$ e mäxima de $18 \mathrm{~m}^{3} / \mathrm{h}$, e capacidade específica média de 0,213 $\left(\mathrm{m}^{3} / \mathrm{h}\right) / \mathrm{m}$, sendo a minima de $0,036\left(\mathrm{~m}^{3} / \mathrm{h}\right) / \mathrm{m}$ e a máxima de 0,67 $\left(\mathrm{m}^{3} / \mathrm{h}\right) / \mathrm{m}$. Observa-se que a capaciaade especifica média está bem acima do valor da mediana $\left(0,06\left(\mathrm{~m}^{3} / \mathrm{h}\right) / \mathrm{m}\right)$ encontrada na análise geral dos dados.

\section{5 - Estimativa das Reservas Hĩaricas Subterrâneas}

- cálculo de reservas de águas subterrāneas alèm de considerar o fator pluviometria, também baseiarse nas caracteristicas aimensionais e hidrodinamicas das unidades aquiferas.

No âmbito do cristalino, a porosidade e condutividade hidrăulica existentes são secundárias, geradas por fraturamento e/ou intemperismo. A relação entre dimensões longitudinais e 
transversais de interconeção e abertura das fraturas, entre outros fatores, gera caracteristicas heterogêneas e anisotrópicas para este contexto.

$\mathrm{Na}$ área em estudo, a atuação intempérica propiciou a formação de espessos mantos de rochas alteradas e, consequentemente, gerou um sistema de porosidade intergranular.

- dimensionamento do potencial hídrico subterrâneo no dominio de rochas precambrianas, onde somente existe condição de infiltração, circulação e armazenamento de ãgua em fraturas, é praticamente impossivel. Assim, esta estimativa de reservas será feita considerando-se somente as unidades aquiferas porosas, neste caso representadas pelo manto de intemperismo e aluviöes.

As reservas de ãguas subterrâneas serão divididas em duas categorias: renováveis, tambëm denominadas de dinâmicas, e permanentes, chamadas de estâticas ou geolögicas.

As renovãveis representam o volume de àgua que participa do ciclo hidrológico numa escala de tempo anual ou sazonal, ou seja, que se encontra em constante movimento.

Não ocorrendo o aproveitamento dessas reservas por obras de captação, este potencial é reintegrado ao ciclo hidrológico através da evapotranspiracão ou constituindo o fluxo de base dos rios. No ültimo caso, o aquifero funcionará como fonte de recarga para à bacia hidrogräfica.

As reservas permanentes representam o volume de água subterrânea que participa do ciclo hidrológico numa escala de tempo plurianual, centenāria ou milenar. E o potencial armazenado abaixo da zona de flutuacão do nível estático. 


\subsection{1 - Reservas Renoväveis}

Considerando-se uma precipitação mëdia de $1.300 \mathrm{~mm} / \mathrm{ano}$ para a região, se tem um volume anual precipitado de $707,6 \times 10^{6}$ $\mathrm{m}^{3}$.

As reservas renováveis podem ser calculadas pela seguinte expressão matemática:

$$
\operatorname{Rr}=\mathrm{A} \cdot \mathrm{Pe}, \text { onde }
$$

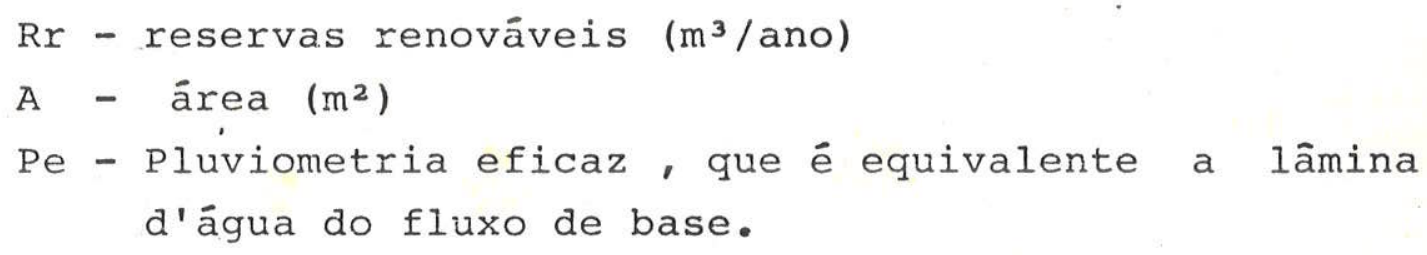

As coberturas aluvionares ocupam uma ärea de $46 \times 10^{6}$ $\mathrm{m}^{2}$, e possuem um volume de recarga da ordem de $7,8 \times 10^{6} \mathrm{~m}^{3} / \mathrm{ano}$ que constituem as reservas renováveis deste aquífero.

O manto de intemperismo recobre uma superficie de 544,4 x $10^{6} \mathrm{~m}^{2}$, para $\circ$ qual se tem um potencial de $92,5 \mathrm{x} 10^{6} \mathrm{~m}^{3} /$ ano para as reservas renováveis.

\section{5 .2 - Reservas permanentes}

As ăguas subterrâneas que representam as reservas permanentes podem ser estimadas pela seguinte expressão:

$$
\mathrm{Rp}=\mathrm{A} \cdot \mathrm{B} \cdot \mu \quad \text {, onde }
$$

$$
\mathrm{Rp} \text { - reservas permanentes }\left(\mathrm{m}^{3}\right)
$$

$A$ - ārea $\left(\mathrm{m}^{2}\right)$ 


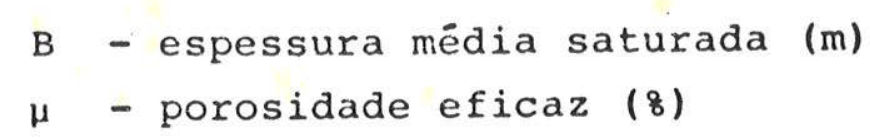

Considerando uma espessura saturada média de 5,0 metros e porosidade eficaz de 58 para as aluviões, as reservas permanentes serão de $11,5 \times 10^{6} \mathrm{~m}^{3}$. Para o manto de intemperismo a espessura média saturada considerada é de 10,0 metros e porosidade eficaz de 28 , o que resultará em um potencial de 108,9 $\mathrm{x} 10^{6} \mathrm{~m}^{3}$ para as reservas permanentes.

Assim, o volume hídrico subterrâneo que constitui as reservas permanentes alcança um total de $120,4 \times 10^{6} \mathrm{~m}^{3}$.

As reservas exploráveis são de dificil quantificação por dependerem da locação e nível tecnológico das obras de captação. Na prática, considera-se que elas constituem $1 / 3$ das reservas totais renováveis.

Foram cadastrados 79 pocos tubulares e 157 poços escavados, sendo que $90 \%$ das vazões dos primeiros situam-se abaixo de $10 \mathrm{~m}^{3} / \mathrm{h}$ e $55 \%$ são inferiores a $5 \mathrm{~m}^{3} / \mathrm{h}$. No caso de todos estarem operando com vazão média de $5 \mathrm{~m}^{3} / \mathrm{h}$, teríamos uma vazão explorada de $405 \mathrm{~m}^{3} / \mathrm{h}$. Considerando que estes poços operam em média $8 \mathrm{~h} /$ dia, o volume explorađo será de $1,16 \times 10^{6} \mathrm{~m}^{3} /$ ano.

As 157 cacimbas operando com vazão média de $1,0 \mathrm{~m}^{3} / \mathrm{h}$ e em regime de bombeamento de 3h/dìa, já que no geral se prestam a uso doméstico, exploram um volume de $471 \mathrm{~m}^{3} / \mathrm{h}$, ou seja, um potencial de $0,17 \times 10^{5} \mathrm{~m}^{3} /$ ano. Desta forma, observa-se que um volume de $1,3 \times 10^{6} \mathrm{~m}^{3}$ de águas subterrâneas está sendo explorado anualmente na região de Atibaia. Tal potencial representa tão somente $1,3 \%$ das reservas renováveis. 


\section{6 - Hidroquimica}

\subsection{1 - Composição e Classificação das Aguas Subterrâneas}

As análises químicas dos ions maiores nas águas subterrâneas, bem como as medidas de condutividade elétrica realizadas no campo servem como suporte básico para a compreensão do grau de mineralização das mesmas (Tabela 03).

A condutividade eletrolitica, ou condutividade elétrica especifica, é a capacidade que uma solução possui de conduzir corrente elétrica e resulta da soma das contribuições dos ions presentes. Como ela depende de todos os ions existentes na solução, não é uma medida qualitativa, mas sim, quantitativa, podendo ser utilizada para estimar-se o grau de mineralização das águas na ausência de análises químicas (LOGAN, 1965; MATTHESS, 1982; HEM, 1985; DRISCOLL, 1986).

Determinações de pH e condutividade elétrica foram realizadas em campo, sendo 157 em águas de poços escavados, 39 em poços tubulares e 12 em fontes, totalizando 208 medidas.

A condutividade elétrica das águas subterrâneas dos poços tubulares, situa-se, predominantemente, entre 80 e 210 $\mu \mathrm{s} / \mathrm{cm}$ (87\%). Porém, observa-se que 50 \% destas ficam restritas ao intervalo de 120 a 160 HS/ cm (Figura 21.a).

Para os poços escavados predominam valores abaixo de 80 $\mu \mathrm{S} / \mathrm{cm}$ (71\%), porém chegando a atingir $210 \mu \mathrm{S} / \mathrm{cm}$ (Figura 21.b). Para as fontes foi realizado um pequeno número de medidas (12) e - maior valor encontrado foi de $87,7 \mathrm{us} / \mathrm{cm}$, enquanto que $50 \%$ delas situam-se abaixo de $40 \mathrm{\mu S} / \mathrm{cm}$.

Assim, evidencia-se uma maior mineralização para as águas dos poços tubulares, em concoraância com os valores observados para os Sólidos Totais Dissolvidos (STD). A 


\begin{tabular}{|c|c|c|c|c|c|c|c|c|c|c|c|c|c|}
\hline \multirow{2}{*}{$\begin{array}{c}\text { AMOSTRA } \\
\text { (№ DE ORDEM/ } \\
\text { ORIGIM) }\end{array}$} & \multicolumn{9}{|c|}{ CONCENTRAÇÃO (mg/1) } & \multicolumn{2}{|c|}{$\mathrm{pH}$} & \multicolumn{2}{|c|}{$\begin{array}{l}\mathrm{COND}_{\cdot} \mathrm{EL} \\
\text { a } 25 \mathrm{OC}\end{array}$} \\
\hline & $\mathrm{Ca}+\mathrm{H}$ & $\mathrm{Mg}++$ & $\mathrm{Na}+$ & $\mathrm{K}+$ & $\mathrm{Cl}^{-}$ & $\mathrm{SO}_{4}=$ & $\mathrm{HCO}_{3}^{-}$ & $\mathrm{NO}_{3}^{-}$ & $\mathrm{CO}_{2}$ livre & I & II & I & II \\
\hline $50 \mathrm{C}$ & 6,2 & 0,7 & $\overline{1,9}$ & 1,3 & 2,0 & $<2,5$ & 32,4 & 0,6 & 64,9 & 6,0 & 5,1 & 103 & 63 \\
\hline $71 \mathrm{C}$ & 4,5 & 0,5 & 1,1 & 2,4 & 0,2 & $<2,5$ & 27,2 & 0,1 & 30,8 & 5,7 & 5,0 & 59 & 47 \\
\hline $72 \mathrm{C}$ & 18,5 & 0,9 & 1,0 & 4,1 & 0,3 & $<2,5$ & 77,2 & 0,2 & 27,5 & 6,9 & 6,5 & 137 & 119 \\
\hline $22 \mathrm{~J}$ & 12,8 & 1,3 & 9,1 & 2,1 & 0,1 & $<2,5$ & 92,1 & 0,1 & 20,9 & 6,0 & 6,4 & 99 & 137 \\
\hline $155 \mathrm{C}$ & 8,1 & 3,4 & 0,7 & 3,5 & 1,8 & $<2,5$ & 54,9 & 4,5 & 39,6 & - & 5,3 & - & 93 \\
\hline $20 \mathrm{~T}$ & 14,3 & 3,3 & 6,6 & 4,0 & 0,5 & $<2,5$ & 85,4 & 3,5 & 26,4 & 6,5 & 6,5 & 157 & 168 \\
\hline $156 \mathrm{C}$ & 9,4 & 2,0 & 4,3 & 2,9 & $<0,1$ & $<2,5$ & 59,3 & 0,8 & 44,0 & - & 5,6 & - & 99 \\
\hline $10 \mathrm{~T}$ & 15,1 & 4,1 & 9,6 & 2,9 & $<0,1$ & $<2,5$ & 109,8 & $<0,01$ & 31,9 & 8,3 & 7,2 & 176 & 172 \\
\hline $157 \mathrm{C}$ & 22,9 & 1,4 & 1,0 & 4,7 & 0,9 & $<2,5$ & 88,3 & 0,4 & 17,6 & - & 6,6 & - & 169 \\
\hline $21 \mathrm{~T}$ & 5,7 & 1,2 & 8,9 & 3,2 & $<0,1$ & $<2,5$ & 63,2 & 0,1 & 27,5 & 5,0 & 6,3 & 76 & 96 \\
\hline $19 \mathrm{~T}$ & 8,5 & 3,5 & 2,7 & 1,5 & $<0,1$ & $<2,5$ & 65,4 & 0,04 & 15,4 & - & 6,5 & - & 98 \\
\hline $14 \mathrm{~J}$ & 6,9 & 0,9 & 9,8 & 1,1 & 0,2 & $<2,5$ & 67,1 & $<0,01$ & 16,5 & 7,7 & 6,1 & 204 & 190 \\
\hline $11 \mathrm{~T}$ & 10,6 & 1,2 & 16,5 & 1,6 & 0,1 & $<2,5$ & 97,6 & $<0,01$ & 15,4 & 8,0 & 8,1 & 133 & 140 \\
\hline $4 \mathrm{~T}$ & 3,2 & 1,2 & 1,9 & 2,3 & $<0,1$ & $<2,5$ & 26,2 & 0,2 & 16,5 & 7,6 & 6,4 & 57 & 41 \\
\hline $36 \mathrm{~T}$ & 6,6 & 2,1 & 5,2 & 3,4 & 1,0 & $<2,5$ & 61,2 & 0,8 & 58,3 & 5,7 & 5,6 & 88 & 99 \\
\hline
\end{tabular}

$C=$ poço escavado

$I$ = medidas em maio/junho/88

II = medidas em outubro/88 (coleta de amostras de águas para anälises químicas)

TABELA 03 - ANÁLISFS FISICO-QUIMICAS - (ELEMENTOS MAIORES E CO 2 LIIVRE) - ATIBAIA (SP) 


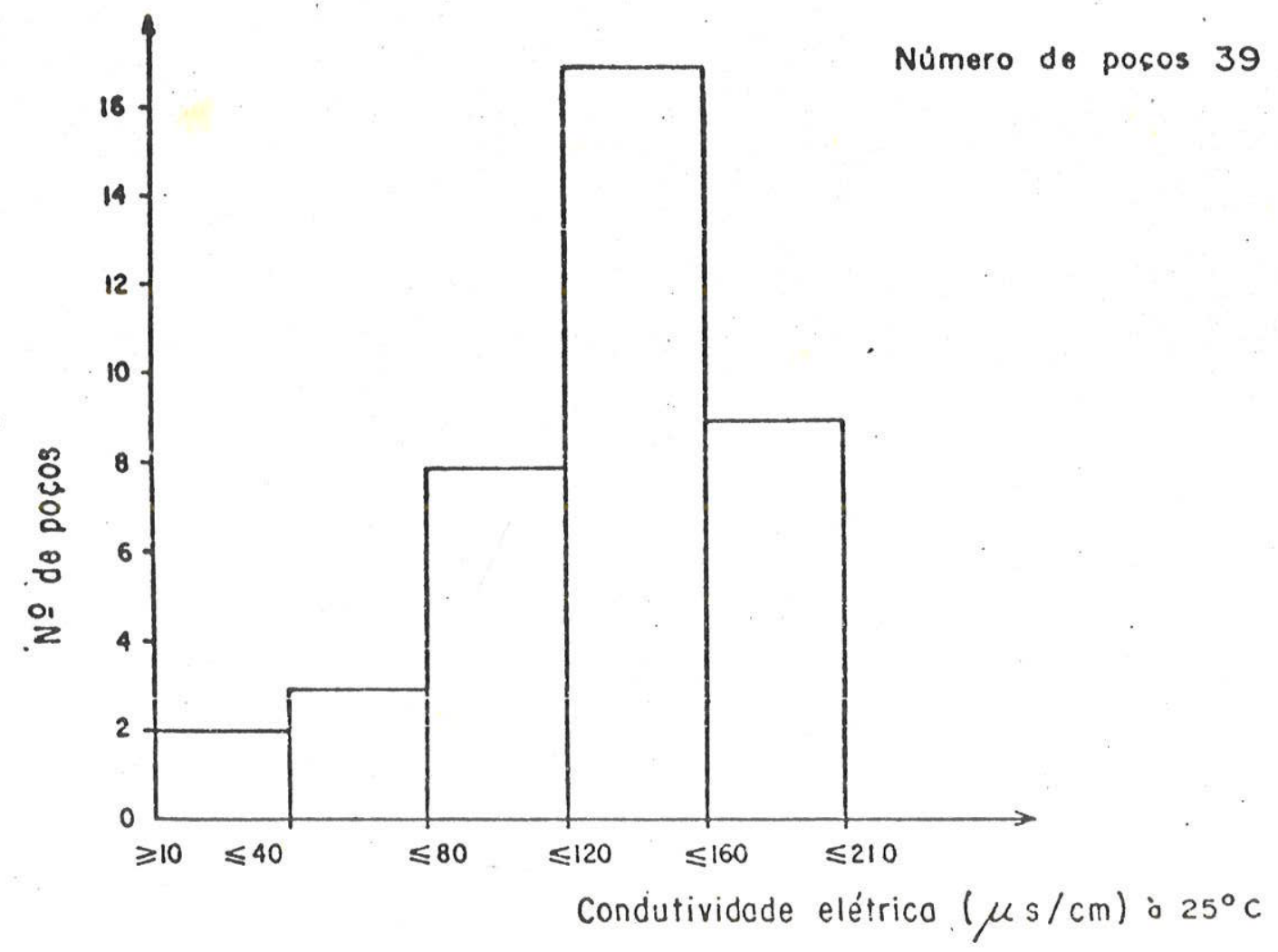

a) poços tubulares

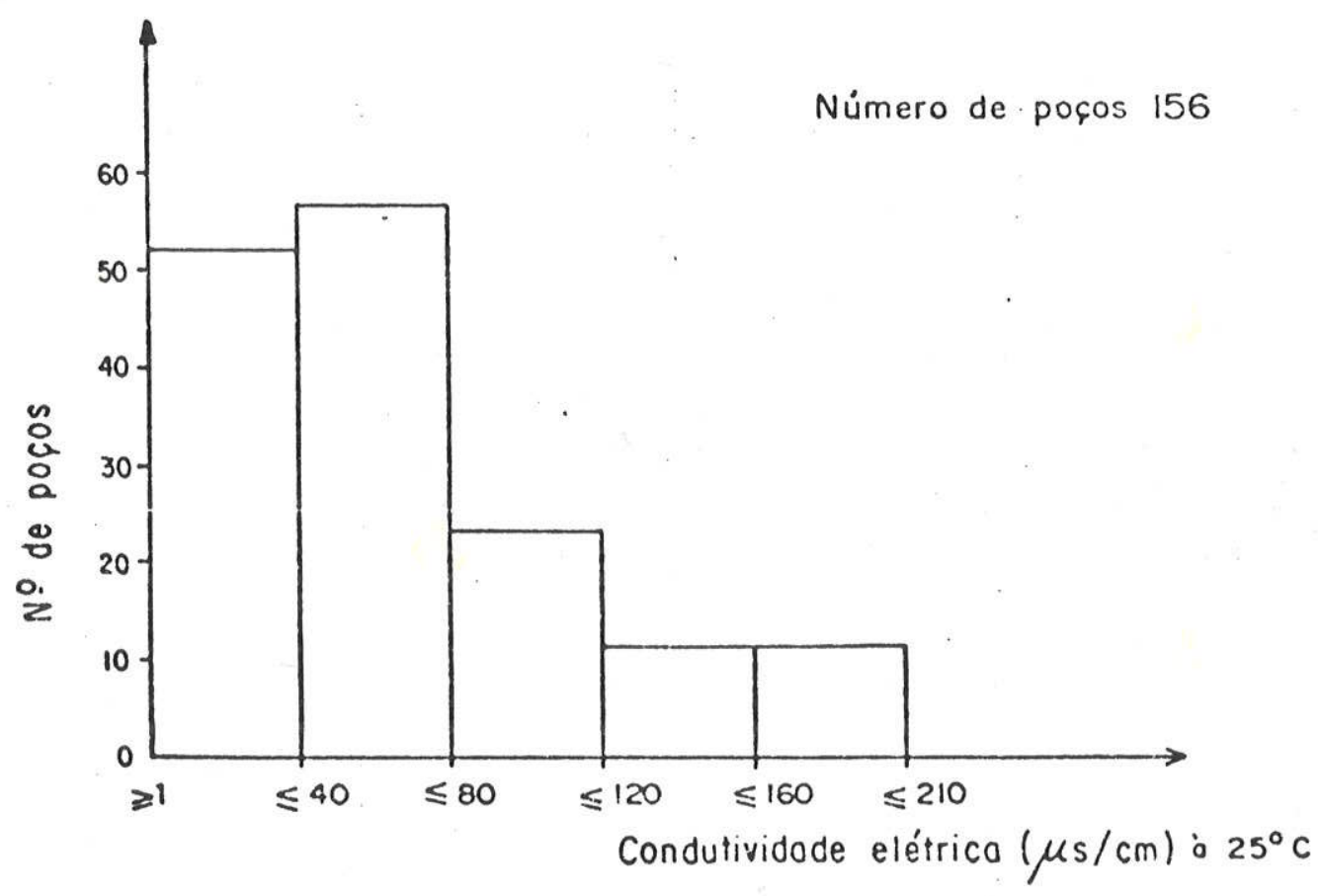

b) poços escovodos

Figura 21 - Distribuiçāo de frequēncia das medidas de condu tividade elétrica específica "in situ" das águas sub terrāneas 
concentração de STD varia de 35 a $142 \mathrm{mg} / 1$, evidenciando águas pouco mineralizadas, sendo que as maiores concentrações pertencem as águas dos poços tubulares, embora 558 delas apresentem STD abaixo de $90 \mathrm{mg} / 1$.

Nas águas dos poços escavados, que são provenientes do manto de intemperismo, os valores de STD são inferiores a 80 $\mathrm{mg} / 1$, com exceção dos poços $72(102,2 \mathrm{mg} / 1)$ e $157(119,6 \mathrm{mg} / 1)$.

O bicarbonato predomina com concentrações entre 26,2 a $109,8 \mathrm{mg} / 1$, seguido pelo cālcio $(3,2$ a $22,9 \mathrm{mg} / 1)$ e sódio $(0,7$ a $16,5 \mathrm{mg} / 1)$.

Os anions nitrato, sulfato e cloreto, e os cátions magnésio e potássio, possuem, de modo geral, baixissimas concentrações com um máximo de $4,5 \mathrm{mg} / \mathrm{l}$.

o gás carbōnico livre apresenta-se relativamente alto, com até $65 \mathrm{mg} / 1$, decorrente da vegetação abundante existente na região e das pequenas profundidades do nivel estático.

$\mathrm{Na}$ tabela 04 constam os resultados encontrados para silício, zinco, ferro, bário e fósforo. O flūor foi detectado somente no poço tubular $22, \operatorname{com} 3,0 \mathrm{mg} / 1$. Outrọs elementos-traço analisados não constam nesta tabela, pois suas concentrações ficaram abaixo dos limites de deteção dos métodos utilizados. são eles:

- prata $(<0,05 \mathrm{mg} / 1)$;

- aluminio $(<0,10 \mathrm{mg} / 1)$;

- boro $(\leqslant 0,02 \mathrm{mg} / 1)$;

- cádmio ( $\leqslant 0,02 \mathrm{mg} / 1)$;

- cromo $(<0,05 \mathrm{mg} / 1)$;

- cobre $(<0,02 \mathrm{mg} / \mathrm{I})$; 


\begin{tabular}{|c|c|c|c|c|c|}
\hline \multirow{2}{*}{$\begin{array}{l}\text { AMOSTRA } \\
\text { (NO DE ORDEM/ } \\
\text { ORIGEM) }\end{array}$} & \multicolumn{5}{|c|}{ CONCENTRAÇAO (mg/1) } \\
\hline & $\mathrm{Si}$ & $\mathrm{Zn}$ & $\mathrm{Fe}$ & $\mathrm{Ba}$ & $\mathbf{P}$ \\
\hline $50 \mathrm{C}$ & 3,3 & 0,02 & 0,2 & 0,04 & $<0,1$ \\
\hline $71 \mathrm{C}$ & 7,8 & $<0,02$ & $<0,02$ & 0,03 & $<0,1$ \\
\hline $72 \mathrm{C}$ & 5,4 & $<0,02$ & $<0,02$ & 0,04 & $<0,1$ \\
\hline $22 \mathrm{~T}$ & 17,6 & 0,3 & $<0,02$ & $<0,02$ & $<0,1$ \\
\hline $155 \mathrm{C}$ & 4,6 & 0,1 & $<0,02$ & 0,2 & $<0,1$ \\
\hline $20 \mathrm{~T}$ & 15,4 & 1,1 & $<0,02$ & $<0,02$ & $<0,1$ \\
\hline $156 \mathrm{C}$ & 15,9 & 0,2 & $<0,02$ & 0,04 & 0,3 \\
\hline $10 \mathrm{~T}$ & 14,8 & 0,7 & $<0,02$ & $<0,02$ & $<0,1$ \\
\hline $157 \mathrm{C}$ & 7,3 & 0,03 & $<0,02$ & 0,08 & 0,2 \\
\hline $21 \mathrm{~T}$ & 24,6 & 1,3 & $<0,02$ & 0,02 & 0,3 \\
\hline $19 \mathrm{~T}$ & 15,5 & 0,1 & $<0,02$ & $<0,02$ & 0,2 \\
\hline $14 \mathrm{~T}$ & 18,4 & 0,02 & $<0,02$ & $<0,02$ & $<0,1$ \\
\hline $11 \mathrm{~T}$ & 13,8 & $<0,02$ & $<0,02$ & $<0,02$ & $<0,1$ \\
\hline $4 \mathrm{~T}$ & 12,1 & 0,03 & $<0,02$ & 0,02 & $<0,1$ \\
\hline $36 \mathrm{~T}$ & 14,7 & 0,2 & 0,02 & 0,06 & $<0,1$ \\
\hline
\end{tabular}

$T=$ poço tubular

$\mathrm{C}=$ poço escavado (cacimba)

TABELA 04 - ANALISES QUIMICAS DE SILICIO E ELEMENTOS-TRAÇO DAS ÁGUAS SUBTERRÃNEAS DE ATIBAIA (SP) 
- manganês $(\leq 0,07 \mathrm{mg} / 1)$;

- chumbo $(<0,10 \mathrm{mg} / 1)$;

- niquel $(<0,02 \mathrm{mg} / 1)$.

As medidas de $\mathrm{pH}$ (Anexo 1 e 2) mostram que as águas dos poços escavados são mais ácidas, com pH geralmente inferior a 6,0 , em comparação com as dos tubulares que apresentam-se acima de 6,0 , atingindo até 8,1 .

$\mathrm{Na}$ figura 22 verifica-se que $\circ \mathrm{pH}$ das águas dos poços tubulares e escavados predomina entre 5,5 a 8,0 (828) e 4,5 a $6,0(758)$, respectivamente. Nas fontes, $\circ \mathrm{pH}$ varia de 4,5 a 6,5, com $75 \%$ abaixo de 6,0 .

Desta forma, observa-se que as águas dos escavados e fontes são, no geral, ácidas. Somente 138 dos tubulares contém ăguas levemente ácidas (pH entre 5,5 e 6,0$)$ e 108 são ácidas (pH menor ou igual a 5,5$)$.

A classificação atravēs do diagrama triangular (Figura 23) mostra que os escavados possuem águas essencialmente bicarbonatadas cálcicas e os tubulares contém águas bicarbonatadas mistas passando para sỏdicas e cálcicas.

\subsection{2 - Evolução da Composição Quimica}

Os aquiferos fraturados possuem caracteristicas peculiares que os distinguem dos demais, tanto sob o aspecto de armazenamento quanto de qualidade das águas.

Os processos e fatores que influenciam na evolução quỉmica das āguas podem ser classificados como intrinsecos e extrinsecos ao sistema aquifero (Figura 24). 


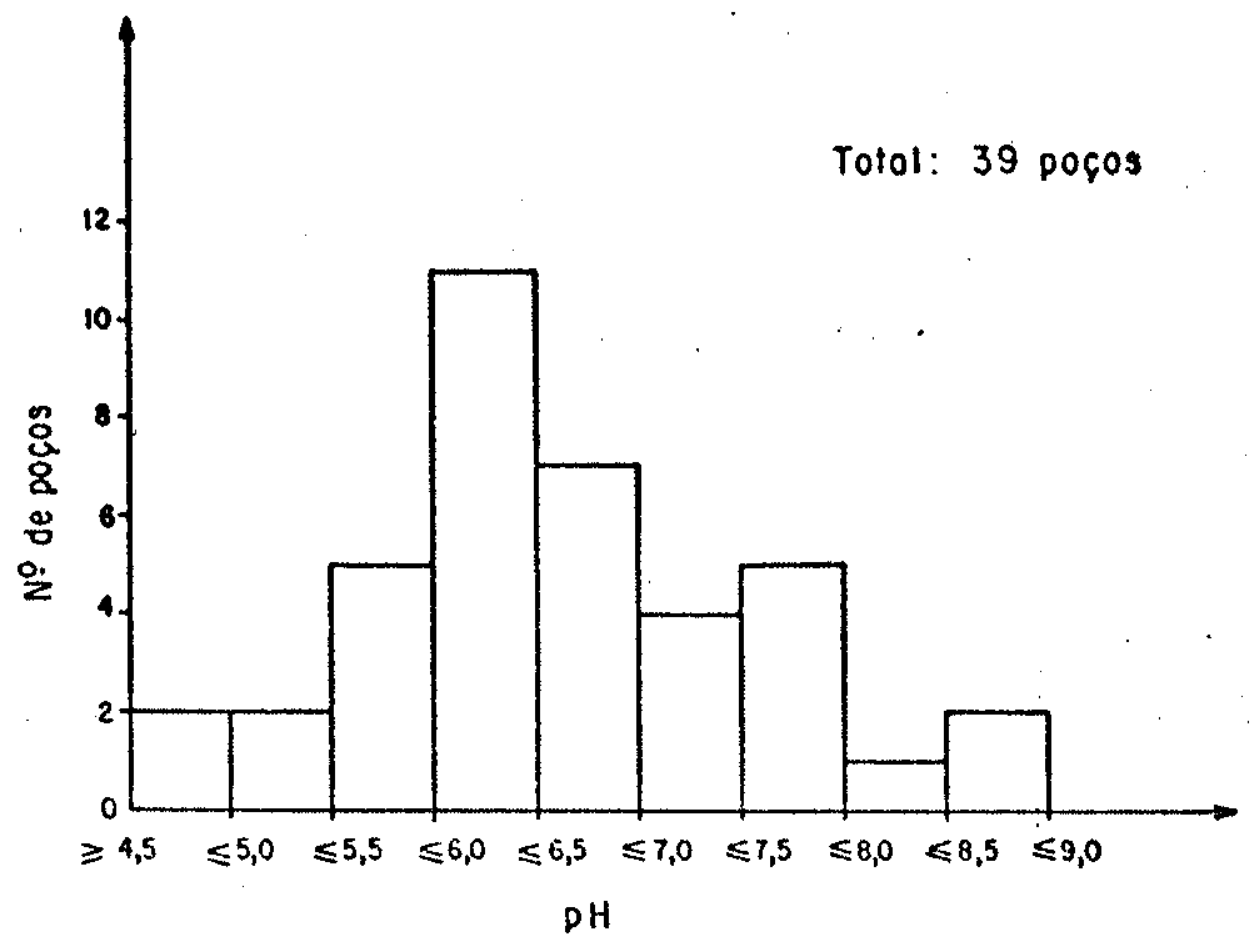

o) poşos tubulares

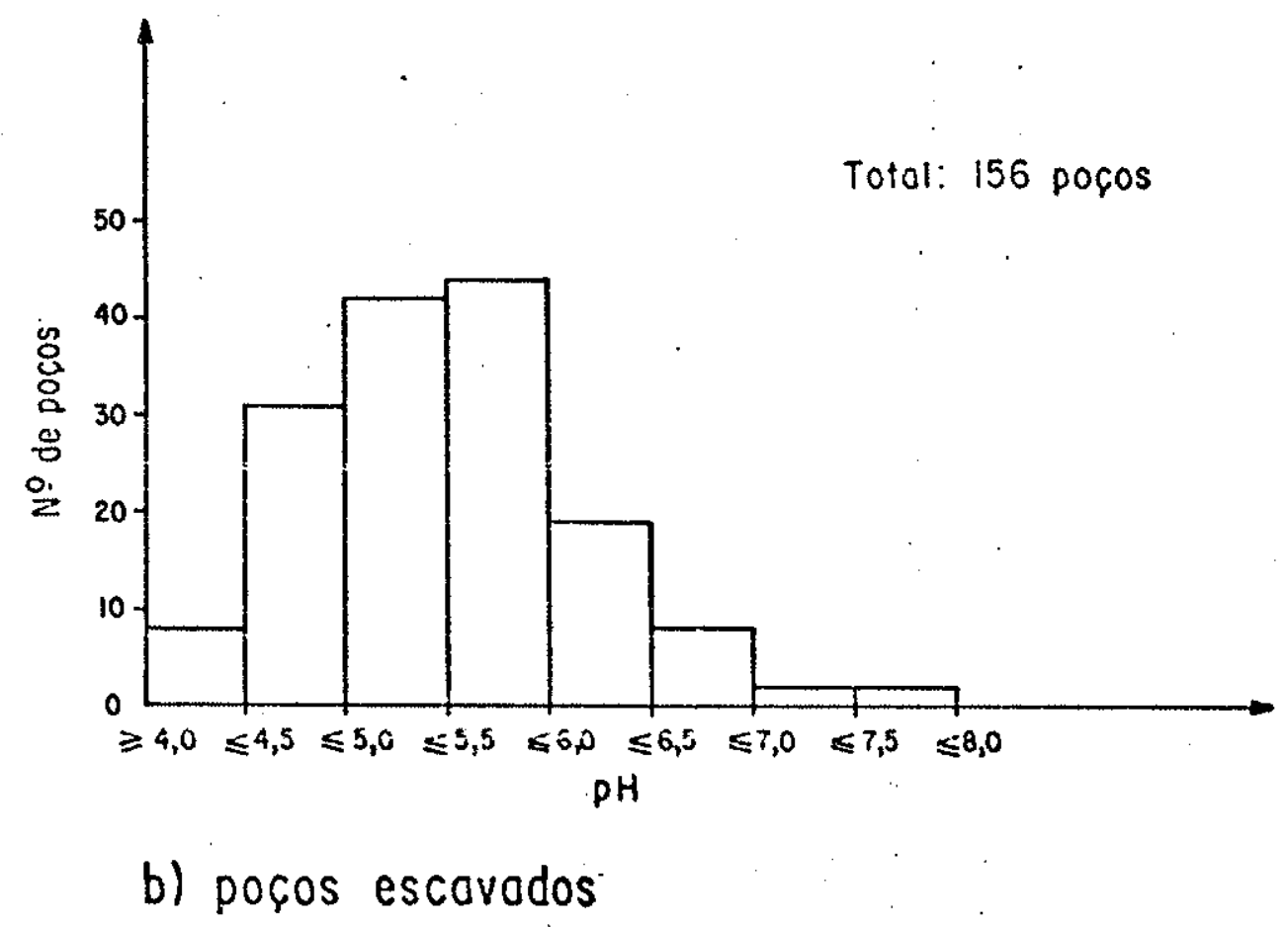

Figura 22 - Distribuiçāo de frequēncia das medidas de $\mathrm{pH}$ "in situ" das águas subterrāneas 

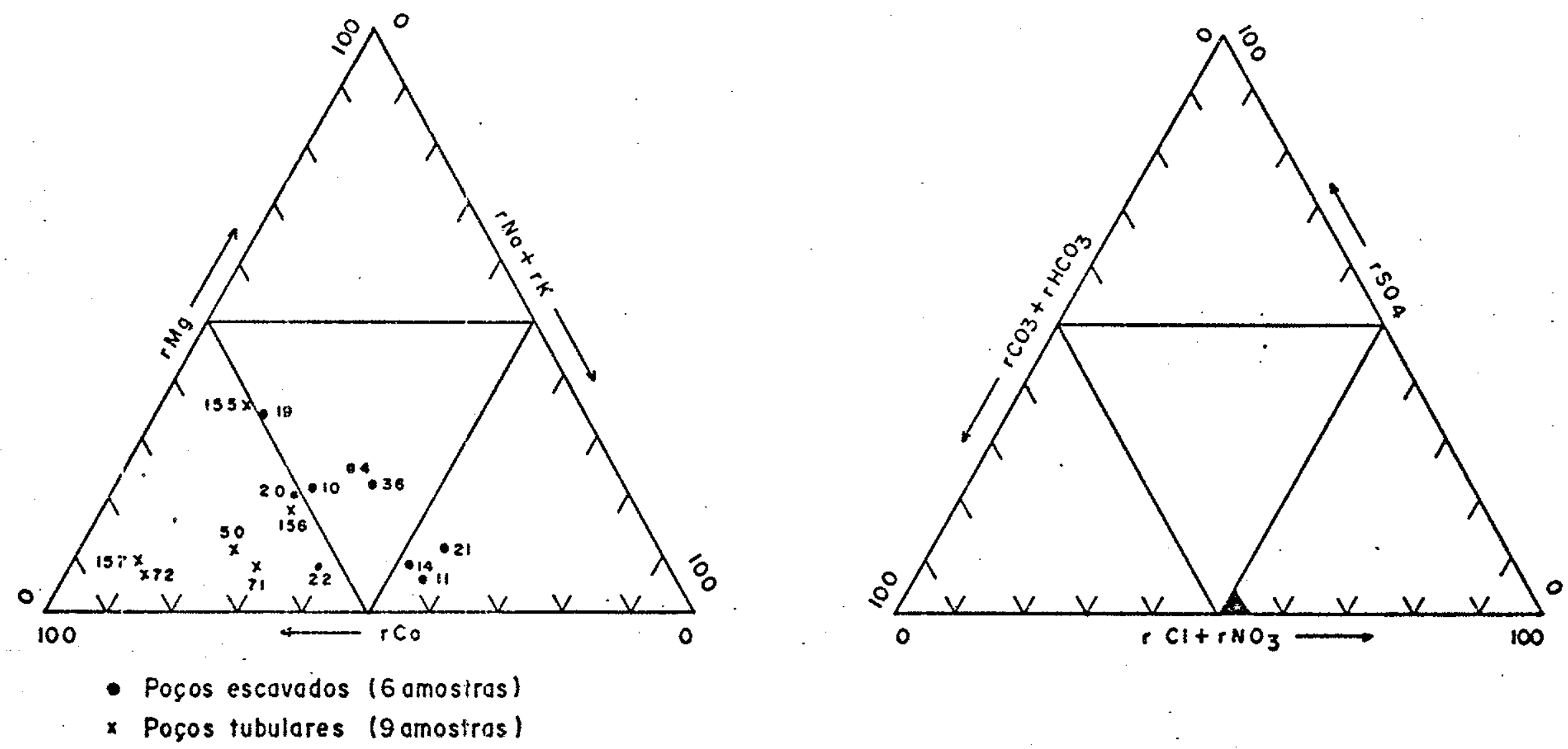

Figura 23 - Diagrama triangular das águas subterrāneas da bacio do rio Atibaia 2 folho Aribaia (SP). 


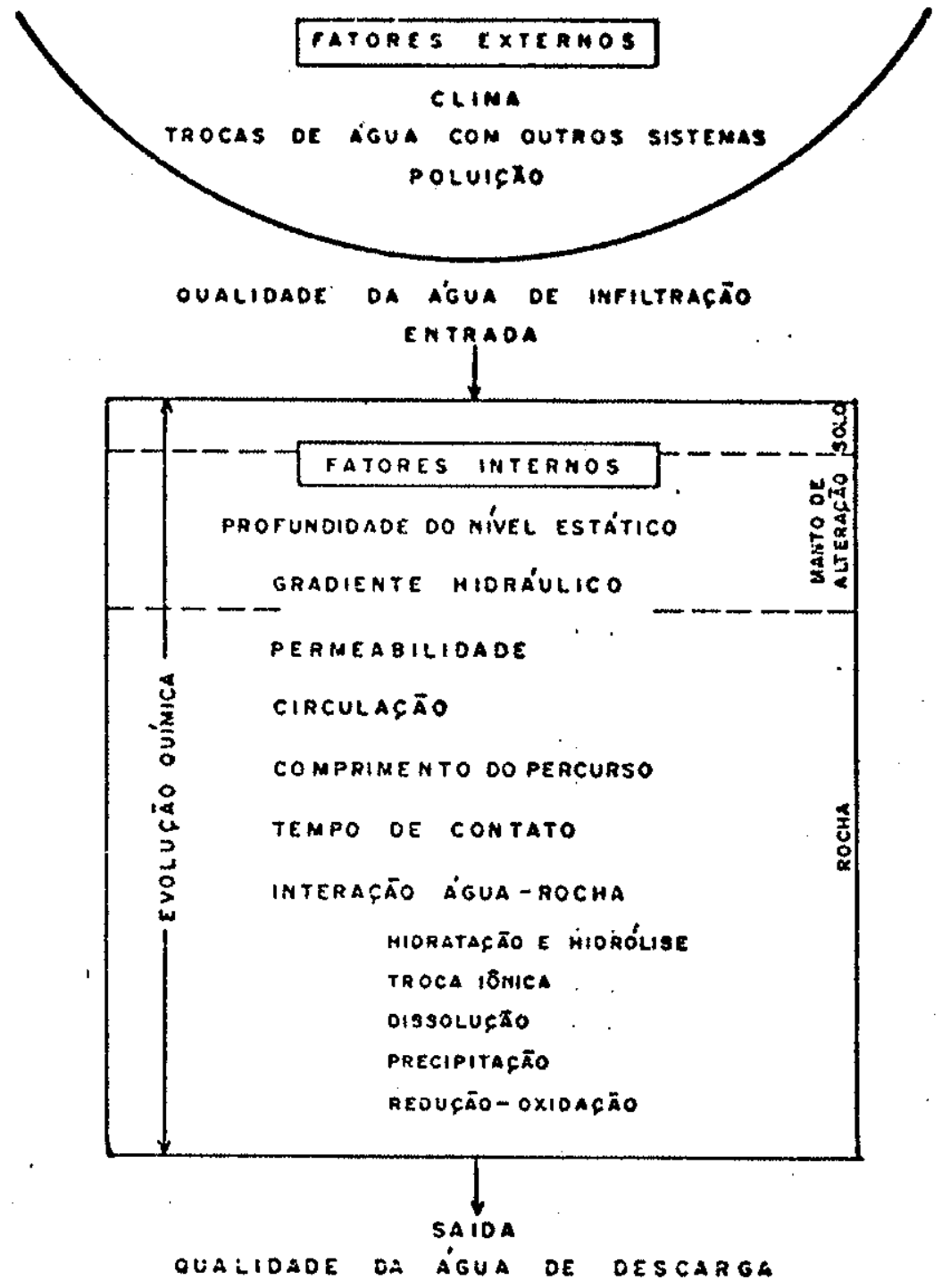

Figura 24 -Fatores que influem na evoliş̄a quimico das águas subterrāneas (CRUz, 1985) 
A existência de uma densa vegetação na ärea de estudo, associada a grande umidade, faz com que existam altos teores de matéria orgânica nos solos gerando, consequentemente, maior produção de gás carbônico.

As águas pluviais contēm entre 0,5 a $0,8 \mathrm{mg} / 1$ de gás carbônico (SZIKSZAY, 1986 ). Porém, à medida que percolam os solos ganham ácido carbônico e se tornam mais ácidas, com maior capacidade de ataque aos minerais.

SCHOELLER (1962) ressalta que o solo è uma das zonas mais ativas na evolução quimica das águas subterrâneas e, a menos que outros fatores interfiram, é nele que elas adquirem uma composicão quase que definitiva.

Nas äguas subterrâneas, $\circ \mathrm{CO}_{2}$ total dissolvido apresenta-se sob a forma de $\mathrm{CO}_{2}$ Iivre $\left(\mathrm{CO}_{2}+\mathrm{H}_{2} \mathrm{CO}_{3}\right)$ e $\mathrm{CO}_{2}$ combinado $\left(\mathrm{HCO}_{3}\right.$ e $\left.\mathrm{CO}_{2}\right)$ de acordo com as seguintes equacões (SIIVA, 1983):

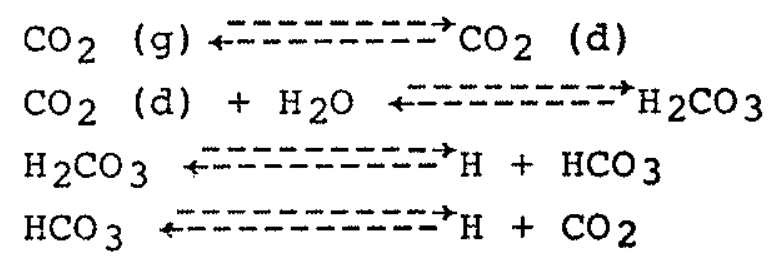

A dissociação do $\mathrm{HCO}_{3}$ dará um carāter ácido as águas e não existirá conaição de existência do $\mathrm{CO}_{3}$, como é observado em Atibaia. Nas análises, $\mathrm{HCO}_{3}$ é dominante e observa-se que ele está em maior concentracão nas águas dos tubulares, tendo comportamento similar ao cálcio e ao sódio.

A origem do $\mathrm{HCO}_{3}$ pode ser explicada pelas reaçöes anteriores, com $\mathrm{CO}_{2}$ provindo da matéria orgānica em estado de decomposição no solo. KRAUSKOPF (1972) diz que dependendo da concentração da matéria orgānica, as águas do solo poderão apresentar $\mathrm{pH}$ igual a 4 ou até ligeiramente inferior. 
- $\mathrm{CO}_{2}$ dissolvido existente no meio aquoso participa da diminuição do $\mathrm{pH}$ das águas, e quanto maior sua concentração maior será a acidez das mesmas (HEM, 1985).

A condição de pH muito baixo para as ăguas do manto de intemperismo, chegando a 4,2 , se deve a produção de ácidos húmicos nos solos. Esta condição é favorecida pelo posicionamento do nivel estático, sub-aflorante, facilitando o aporte direto das águas que percolam a zona sub-saturada.

A medida que aumenta a profundidade do nível estático, observa-se a evolução do pH para um termo alcalino. Isto é nítido nos poços escavados com profundidades acima de 15 metros, onde 0 pH situa-se entre 6,0 e 7,0.

Os poços tubulares com águas ácidas nos mostram que existe contribuição direta àa águas do manto de intemperismo para o meio fraturado, como também testemunham os piezômetros instalados.

- pH acima de 7,0 para as águas de poços escavados encontra explicação no ato de se adicionar cal virgem ou cloro às mesinas (informação verbal de proprietários).

As litologias existentes na área são representadas preaominantemente por rochas gnaissicas-migmatiticas e graniticas, onde os alumino-silicatos constituem a composição mineralógica básica (Tabela 05).

- ataque por soluçōes aquosas aos minerais, existindo consequentemente a liberação de ions, é o principal processo natural de mineralização das águas subterrâneas, sendo que o mecanismo essencial de alteração dos silicatos em clima tropical è a hidrólise (PEDRO, 1964 in PARISOT; 1983; KRAUSKOPF, 1972; FREEZE \& CHERRY, 1979; MATTHESS, 1982; HEM, 1985; KAY, 1987). Este processo se desenvolve com a permanência do aluminio no 


\begin{tabular}{|c|c|c|c|c|c|c|c|c|c|c|c|c|c|c|c|c|c|c|c|c|}
\hline AMOSTRA & 1. & 2 & 3 & 4 & 5 & 6 & 7 & 8 & 9 & 10 & 11 & 12 & 13 & 1.4 & 15 & 16 & 17 & 18 & 19 & 20 \\
\hline $\mathrm{SiO}_{2}$ & 49,5 & 53,8 & 65,2 & 61,8 & 60,9 & 57,9 & 52,6 & 55,5 & 66,0 & 65,3 & 63,8 & 70,8 & 64,6 & 66,2 & 66,2 & 74,6 & 72,6 & 73,5 & 72,1 & 73,9 \\
\hline $\mathrm{Al}_{2} \mathrm{O}_{3}$ & 15,3 & 12,8 & $14,(1$ & 15,0 & 14,8 & 15,3 & 14,1 & 12,7 & 13,8 & 14,0 & 14,7 & 14,1 & 15,8 & 12,9 & 14,0 & 12,4 & 13,3 & 14,2 & 13,2 & 13,0 \\
\hline $\mathrm{FeO}$ & 8,2 & 9,1 & 3,4 & 4,0 & 4,3 & 4,7 & 9,6 & 5,9 & 2,3 & 2,5 & 2,4 & 1,8 & 3,6 & 4,8 & 3,2 & 0,9 & 1,4 & 0,7 & 1,0 & 0,9 \\
\hline $\mathrm{Fe}_{2} \mathrm{O}_{3}$ & 3,6 & 2,0 & 2,0 & $.1,5$ & 1,8 & 3,2 & 1,9 & 2,3 & 2,1 & 2,0 & 2,2 & 1,0 & 1,2 & 1,6 & 1,3 & 0,3 & 0,3 & 0,4 & 0,6 & 0,5 \\
\hline $\mathrm{CaO}$ & 8,3 & 10,4 & 3,0 & 4,5 & 4,8 & 6,2 & 9,4 & 6,4 & 3,0 & 3,3 & 2,9 & 2,2 & 4,0 & 3,5 & 3,5 & 1,6 & 1,6 & 1,0 & 0,7 & 0,9 \\
\hline $\mathrm{MgO}$ & 4,0 & 7,3 & 3,8 & 2,8 & 2,7 & 3,0 & 7,3 & 8,8 & 1,7 & 1,6 & 1,5 & 0,7 & 1,5 & 2,8 & 1,9 & 0,3 & 0,5 & 0,3 & 0,3 & 0,4 \\
\hline $\mathrm{Na}_{2} \mathrm{O}$ & 3,9 & 1,0 & 1,3 . & 3,4 & 3,5 & 3,6 & 1,4 & 2,5 & 4,0 & 4,1 & 3,9 & 3,6 . & 3,0 & 2,2 & 3,0 & 3,0 & 2,6 & 3,8 & 2,6 & 3,6 \\
\hline $\mathrm{K}_{2} \mathrm{O}$ & 1,5 & 0,5 & 4,2 & 4,1 & 3,6 & 1,6 & 0,8 & 2,8 & 4,4 & 4,8 & 4,5 & 4,2 & 3,8 & 2,3 & 4,0 & 5,0 & 5,8 & 4,9 & 7,5 & 5,0 \\
\hline$P_{2} O_{5}$ & 0,9 & 0,07 & 0,2 & 0,4 & 0,4 & 0,5 & 0,2 & 0,3 & 0,6 & 0,6 & 0,5 & 0,2 & 0,4 & 0,05 & 0,3 & 0,1 & 0,05 & 0,07 & 0,1 & 0,3 \\
\hline
\end{tabular}

A) OxIDOS (\%)

\begin{tabular}{|c|c|c|c|c|c|c|c|c|c|c|c|c|c|c|c|c|c|c|c|c|}
\hline AMOSTRA & 3. & 2 & 3 & $I_{4}$ & 5 & 6 & 7 & 8 & 9 & 10 & 11 & 12 & 13 & 14 & 15 & 16 & 17 & 18 & 19 & 20 \\
\hline $\begin{array}{l}\mathrm{Ba} \\
\mathrm{Zn}\end{array}$ & $\begin{array}{l}6010 \\
11.0\end{array}$ & $\leq 20$. & $\begin{array}{r}1150 \\
. \quad 67\end{array}$ & $\begin{array}{r}1400 \\
74\end{array}$ & $\begin{array}{r}980 \\
72\end{array}$ & $\begin{array}{r}1050 \\
78\end{array}$ & $\begin{array}{l}80 \\
96\end{array}$ & $\begin{array}{r}685 \\
73\end{array}$ & $\begin{array}{r}2300 \\
80\end{array}$ & $\begin{array}{r}2050 \\
85\end{array}$ & $\begin{array}{r}2250 \\
73\end{array}$ & $\begin{array}{r}550 \\
55\end{array}$ & $\begin{array}{r}2400 \\
94\end{array}$ & $\begin{array}{r}280 \\
50\end{array}$ & $\begin{array}{r}1100 \\
62\end{array}$ & $\begin{array}{r}825 \\
16\end{array}$ & $\begin{array}{r}935 \\
79\end{array}$ & $\begin{array}{r}685 \\
24\end{array}$ & $\begin{array}{r}740 \\
30\end{array}$ & $\begin{array}{r}1450 \\
31\end{array}$ \\
\hline
\end{tabular}

B) FLDMENTOS MEXORES (mg/1)

$\begin{array}{llll}1 \text { - Anfibolito } & 6 \text { - Gnaisse quartzo-dioritico } & 11 \text { - Riodacito } & 16 \text { - Biotita-granada gnaisse } \\ 2 \text { - Anfibolito } & 7 \text { - Biotita-anfibolito } & 12 \text { - Gnaisse granodioritico } & 17 \text { - Granada-biotita granito } \\ 3 \text { - Biotita xisto } & 8 \text { - Meta-quartzo dioritico } & 13 \text { - Blotita gnaisse } & 18 \text { - Biotita-moscovita granito } \\ 4 \text { - Meta-tonalito } & 9 \text { - Meta-andesito } & 14 \text { - Biotita-granada gnaisse } & 19 \text { - Granito } \\ 5 \text { - Meta-tonalito } & 10 \text { - Meta-andesito } & 15 \text { - Biotita hornblenda gnaisse } & 20 \text { - Riodacito }\end{array}$

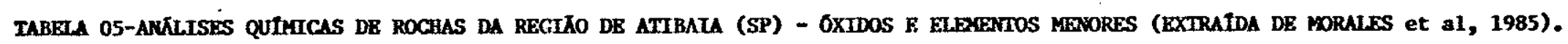


perfil de alteração e eliminação, parcial ou total, de silica e bases, ocorrendo entre um $\mathrm{pH}$ de 5,0 a 9,6. O fluxo da solução diluida pode ser variável, o que irá caracterizar os diferentes graus da hidrólise (MELFI, 1986).

A caracterização da hidrólise foi realizada à partir do conhecimento dos minerais primários e secundários envolvidos nas reações, e a cada grau corresponde uma fase solúvel de composição bem determinada contendo silica e bases. O sistema é aberto e as àguas de drenagem evacuam os elementos de modo que é impossivel estabelecer um balanço global entre o momento em que o mineral comeca a se alterar e o momento em que ele desaparece completamente (MELFI, op. cit.).

A silica é o óxido mais abundante nas rochas da região, alcançando 74,6 \%. Na hidrólise ela é liberada dos silicatos, sendo que parte fica sob a forma de colóides e parte dissolvida, e a solubilidade é diretamente proporcional ao pH (CORRENS, 1940 in MATTHESS, op. cit.).

A taxa de solução aquosa que percola a litologia, bem como os ácidos naturais, funcionam como catalizadores nas reações intempëricas e afetam o grau de silica dissolvida nas águas.

Para um $\mathrm{pH}$ inferior a 9,0 e teor de silica menor que $64,3 \mathrm{mg} / \mathrm{l}$ (ou $30 \mathrm{mg} / \mathrm{l}$ de $\mathrm{Si}$ ) a principal forma molecular em que o silicio dissoivido encontra-se nas águas subterrāneas é $\mathrm{Si}_{(\mathrm{OH})_{4}}$ (KRAUSKOPF, op. cit.; FREEZE \& CHERRY, op. cit.; HEM, op. cit.) Nas amostras estudadas a concentração de silício estä entre 3,3 e $24,6 \mathrm{mg} / 1$ e crescem com o aumento do $\mathrm{pH}$.

- $\mathrm{A}_{2} \mathrm{O}_{3}$ nas rochas precede a silica alcançando $15,8 \%$. Porém, a concentração de aluminio detectada nas águas analisadas fica abaixo de $0,1 \mathrm{mg} / \mathrm{I}$, e isto pode ser explicado pelo fato deste óxido não ser solubilizado durante a hidrólise, ficando retido nas estruturas dos argilo-minerais. 
Apesar dos teores elevados de FeO $(9,18)$ e $\mathrm{Fe}_{2} \mathrm{O}_{3}(3,68)$ nas rochas da região, e provindos dos minerais ferro-magnesianos (principalmente da biotita), a concentraço nas águas subterrâneas do ion $\mathrm{Fe}$ é inferior a $0,2 \mathrm{mg} / 1$. Certamente este ion ao ser liberado é imediatamente oxidado a ferro férrico, insolúvel, permanecendo no perfil de alteração.

o teor de bārio encontrado nas litologias é de 2.400 $\mathrm{mg} / 1$ e abaixo de $0,2 \mathrm{mg} / \mathrm{l}$ nas águas subterrâneas. Isto se deve ao caráter insolúvel deste elemento nas condições ambientais. 0 comportamento do zinco é similar ao do bário (FETTER, 1980).

GOLDICH, 1938 (in MELLO, 1975; PARISOT, 1983; MELFI, 1986) determinou uma série de estabilidade considerando somente a estrutura dos minerais cristalizados em altas temperaturas, quando eles são expostos a condições exógenas.

Observa-se que a estabilidade à alteração é diretamente proporcional a complexidade das ligações si-o-si, e quando comparada a Série de Bowen verifica-se que os primeiros minerais a se cristalizarem são os mais susceptiveis a transformacões.
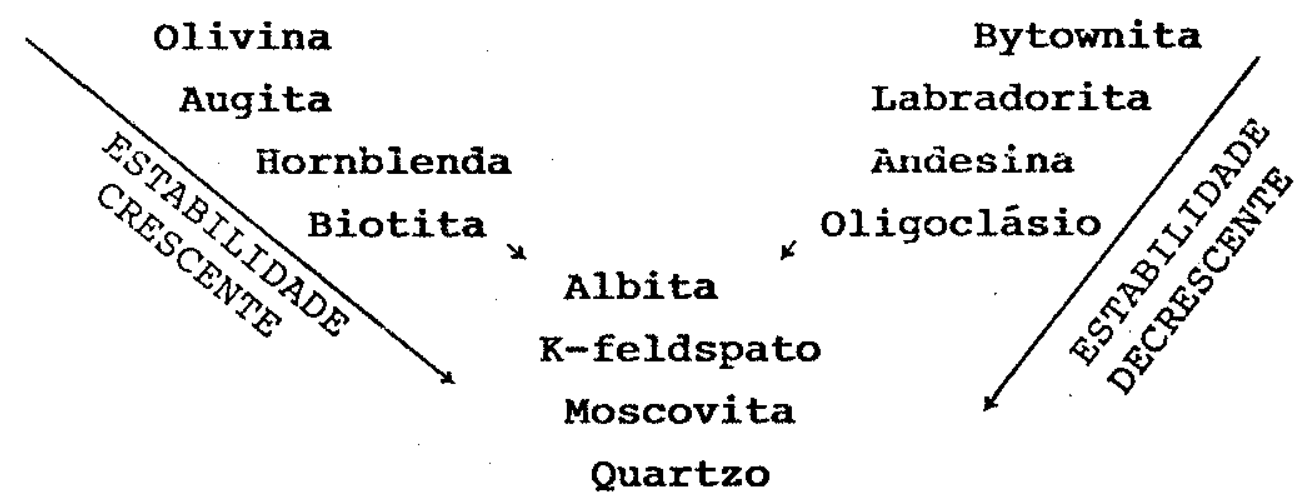

Tabela 06 - série de estabilidade dos minerais primärios formadores de rochas, determinada por GOLDICH, 1938 (MELLO, 1975) • 
A predominância do cālcio nas äguas, seguido algumas vezes do södio, se deve a alteração dos plagioclásios ricos em cálcio e cálcio-sódio que apresentam o menor grau de estabilidade, alterando-se rapidamente quando submetidos a condições externas e liberando esses ions para as äguas subterrâneas.

o potássio origina-se, predominantemente, da alteração da biotita e, secundariamente, do feldspato potássico e moscovita. Ele possui um diâmetro atômico igual a distância inter-camadas da estrutura de alguns argilo-minerais e isto faz com que ele tenha uma forte tendência de ser incorporado nestes minerais, seja atravës de troca iônica ou por adsorção iônica.

Nas águas do manto de intemperismo ele sempre precede o cálcio, não acontecendo o mesmo nas dos poços tubulares. No manto, as águas são mais recentes e embora o potássio migre para os argilo-minerais, o menor tempo de residência das äguas faz com que exista maior concentração deste elemento.

- magnésio é liberado principalmente da hornblenda e biotita. Sua baixa concentraçao entre os ions principais se deve a processos de troca iônica após ser lixiviado pela hidrólise.

o cloxeto não é comum nas rochas cristalinas e sua ocorrência é relacionada as ãguas pluviais. A maior concentração ocorre nas águas do manto de intemperismo, atingindo até $2,0 \mathrm{mg} / \mathrm{I}$, e isto se deve as caracteristicas estruturais dos argilo-minerais que dificultam a passagem deste ion.

- nitrogēnio pode ocorrer em diferentes estados de oxidação, desde $\mathrm{N}^{-3}$ até $\mathrm{N}^{-5}$, sendo que em meio aquoso $0 . \mathrm{N}^{-3}$, $\mathrm{N}^{+3}$ e $\mathrm{N}^{+5}$ formarão, respectivamente, $\circ \mathrm{NH}_{4}^{+}, \mathrm{NO}_{2}^{-}$e $\mathrm{NO}_{3}^{-}$(PIUCCI, 1978). O $\mathrm{NO}_{3}^{-}$encontra-se presente nas águas subterrâneas da região e deriva da decomposicão da matéria orgãnica. 
o fluor só foi encontrado nas äguas do poço tubular No $22(3,0 \mathrm{mg} / 1)$ e sua origem aparentemente não está relacionada com a litologia local. BERTACHINI (1987) determinou concentracões de até $4,0 \mathrm{mg} / \mathrm{I}$ deste elemento nas ăguas subterrāneas de Jundiai, limite com Atibaia, porém não explica sua origem. QUIST (1987) cita valores entre 2,0 e $5,0 \mathrm{mg} / 1$ para as águas do embasamento cristalino de Ghana (Africa) e cogita derivarem de granitos intrusivos.

TARDY, 1969 (in PARISOT, op. cit.) estudou a composição quimica das águas subterrâneas de diferentes ambientes cristalinos e observou que a razão $\mathrm{rNa} / \mathrm{rK}$ pode servir como índice de alteração dos feldspatos, onde os baixos valores correspondem a uma alteração que atinge toda esta classe mineralógica. Este autor correlaciona, ainda, a hidrólise total dos silicatos com meios bem drenados em que as soluções são diluidas, e a hidrólise parcial com meios confinados onde as soluçōes são mais concentradas.

Em Atibaia, observa-se que a razão $r N a / r K$ para as águas dos poços escavados e tubulares variam entre 0,2 a 2,7 e 1,6 a 23,7 , respectivamente, indicando que no manto de intemperismo todos os feldspatos são afetados pela hidrólise, enquanto o mesmo não acontece no meio fraturado. Relacionado a concentração iônica, as águas dos tubulares são mais concentradas.

GARREL (1957) e GARREL \& CHRIST (1965), in MELFI, Op. cit., desenvolveram o método termodinâmico para caracterizar os diferentes dominios da hidrólise e através do conhecimento de outros parâmetros, tais como o produto de solubilidade e a constante de equilibrio das reações, se pode estabelecer diagramas de estabilidade para cada mineral e verificar a relação entre a composição iônica da ägua $e$ os coṇstituintes mineralógicos das rochas. 
A figura 25 mostra que as äguas dos pocos escavados situam-se no campo da monossialitização, onde através da eliminação parcial da sílica e total de bases se tem a formação da caolinita, como mostra, por exemplo, a reação abaixo

$$
\begin{gathered}
2\left(\mathrm{Si}_{3} \mathrm{Al}\right) \mathrm{O}_{8} \mathrm{~K} \\
\text { ortocläsio }
\end{gathered}-\underset{\mathrm{Si}_{2} \mathrm{Al}_{2} \mathrm{O}_{5}(\mathrm{OH})_{4}}{\text { caolinita }}+\underset{\text { solução }}{\mathrm{Si}(\mathrm{OH})_{4}}+(\mathrm{K}, \mathrm{OH})
$$

A medida em que a profundidade aumenta, as águas gradam para um dominio da bissialitização, com eliminação parcial de silica e bases e culminando com a formação da montmorilonita, sericita e vermiculita, que são argilo-minerais mais ricos em silica.

A tabela 07 mostra que ás águas dos.poços escavados possuem uma menor concentração de silica do que as dos poços tubulares e, quando correlacionada ao gráfico de estabilidade, verifica-se uma gradação deste óxido do campo da caolinita para o da montmorilonita cálcica.

Desta forma, tem-se a caolinita e a montmorilonita cálcica como os dois principais argilo-minerais liberadores dos ions principais para as águas subterrâneas de Atibaia.

\subsection{3 - Uso das Aguas}

A qualidade das águas naturais é reflexo da composição Î́sico-química. A adequabilidade para cada uso varia em função da finalidade proposta e dos constituintes que possam afetá-la, existindo diversos pađrões com limites sugeridos que procuram reger a utilizaça para o consumo humano, agrícola e industrial.

Ressalta-se que o objetivo deste trabalho não è, especificamente, a hidroquímica $e$, por esta razão, alguns elementos e parāmetros não foram analisados, tais como dureza e alcalinidade, bem como as caracteristicas bacteriológicas. 


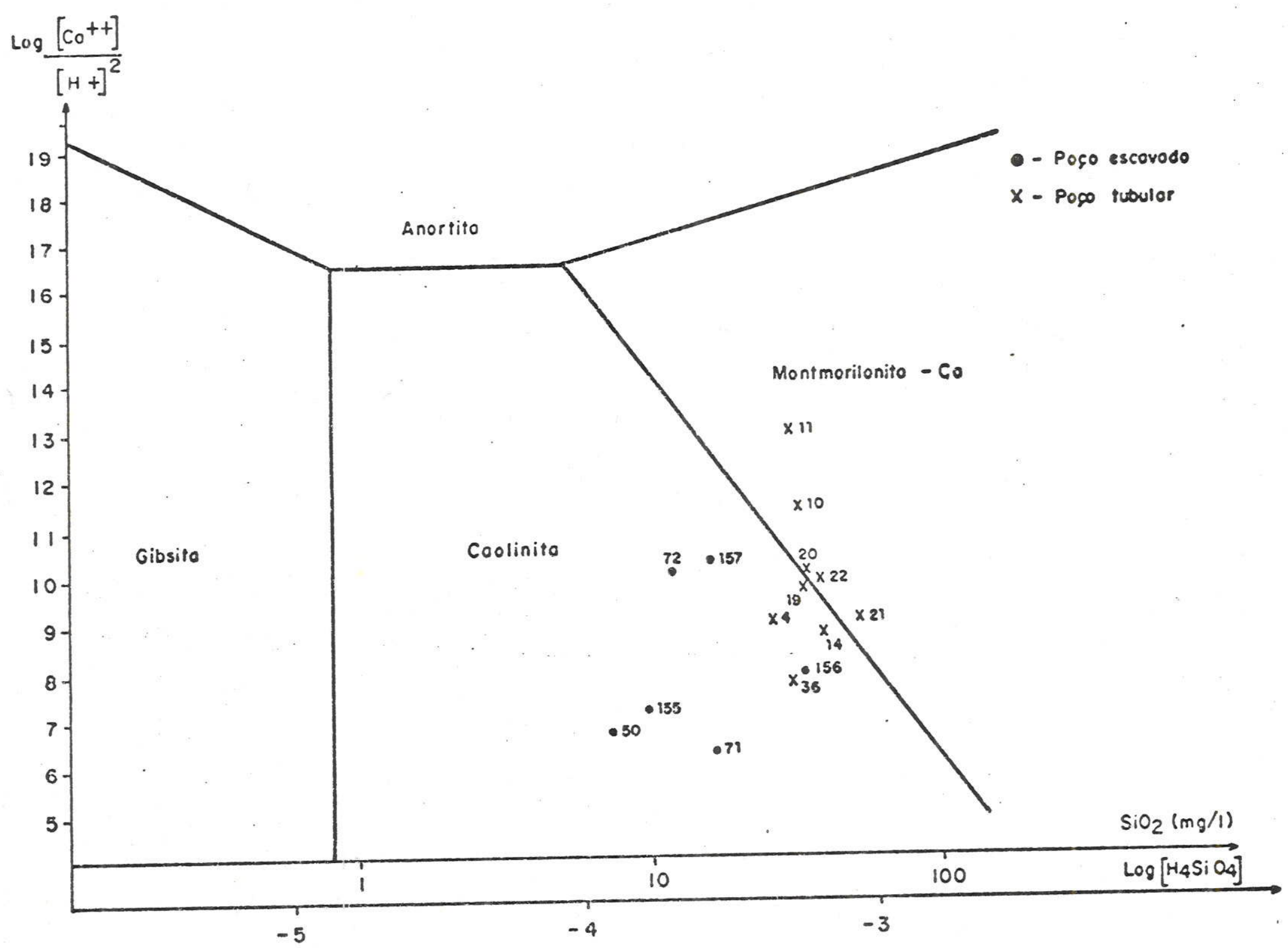

Figura 25 - Diagrama de estabilidade do sistema $\mathrm{CaO}, \mathrm{Al}_{2} \mathrm{O}_{3}, \mathrm{SiO}_{2}, \mathrm{H}_{2} \mathrm{O}$ à $25^{\circ} \mathrm{C}$ e $1 \mathrm{~atm}$. 


\begin{tabular}{|c|c|c|c|c|}
\hline $\begin{array}{l}\text { AMOSTRA } \\
\text { (NO DE OKIEYY } \\
\text { ORIGEY) } \\
\end{array}$ & $\begin{array}{l}\mathrm{Ca}++ \\
\mathrm{eg} / \mathrm{g}\end{array}$ & $\mathrm{pH}$ & $\log [\mathrm{Ca}++]+2 \mathrm{pH}$ & $\begin{array}{r}\mathrm{SiO}_{2} \\
(\mathrm{mg} / \mathrm{l}) \\
\end{array}$ \\
\hline $50 \mathrm{C}$ & $3,0 \times 10^{-4}$ & 5,1 & 6,7 & 7,1 \\
\hline $71 \mathrm{C}$ & $2,2 \times 10^{-4}$ & 5,0 & 6,3 & 16,7 \\
\hline $72 \mathrm{C}$ & $9,2 \times 10^{-4}$ & 6,5 & 10,0 & 11,6 \\
\hline $22 \mathrm{~T}$ & $6,3 \times 10^{-4}$ & 6,0 & 8,8 & 37,7 \\
\hline $155 \mathrm{C}$ & $4,0 \times 10^{-4}$ & 5,3 & 7,2 & 9,8 \\
\hline $20 \mathrm{~T}$ & $7,1 \times 10^{-4}$ & 6,5 & 9,9 & 32,9 \\
\hline $156 \mathrm{C}$ & $4,6 \times 10^{-4}$ & 5,6 & 7,9 & 34,0 \\
\hline $10 \mathrm{~T}$ & $7,5 \times 10^{-4}$ & 7,2 & 11,3 & 31,7 \\
\hline $157 \mathrm{C}$ & $1,1 \times 10^{-3}$ & 6,6 & 10,3 & 15,6 \\
\hline $21 \mathrm{~T}$ & $2,8 \times 10^{-4}$ & 6,3 & 9,0 & 52,6 \\
\hline $19 \mathrm{~T}$ & $4,2 \times 10^{-4}$ & 6,5 & 9,6 & 33,2 \\
\hline $14 \mathrm{~T}$ & $3,4 \times 10^{-4}$ & 6,1 & 8,7 & 39,4 \\
\hline $11 \mathrm{~T}$ & $5,2 \times 10^{-4}$ & 8,1 & 12,9 & 29,5 \\
\hline $4 \mathrm{~T}$ & $1,5 \times 10^{-4}$ & 6,4 & 9,0 & 25,9 \\
\hline $36 \mathrm{~T}$ & $3,2 \times 10^{-4}$ & 5,6 & 7,7 & 31,4 \\
\hline
\end{tabular}

$$
\begin{aligned}
& \mathrm{T}=\text { poço tubular } \\
& \mathrm{C}=\text { poço escavado (cacimba) }
\end{aligned}
$$

TABELA 07 - VALORES UTTLIZADOS NO DTAGRAMA DE ESTABILIDADE DO SISTEMA CaO, $\mathrm{Al}_{2} \mathrm{O}_{3}$. $\mathrm{SiO}_{2}$ e $\mathrm{H}_{2} \mathrm{O}$ a $250 \mathrm{C}$ e $1 \mathrm{~atm}$. 
A seguir serão realizadas algumas considerações quanto a qualidade das águas subterrâneas da região de Atibaia e suas utilizações.

\section{Consumo Humano}

Como mostram as tabelas 03 e 04 (páginas 59, 62), no geral estas ãguas são adequadas ao consumo humano. Com excecão do $\mathrm{pH}$, que pode ser facilmente corrigido, e ao fluor observado no poço tubular Ne $22(3,0 \mathrm{mg} / 1)$, não existe qualquer restrição à potabilidade destas águas no que diz respeito aos elementos analisados.

Um fato que deve ser ressaltado é a cultura de morangos e rosas na região que chega a ocupar um espaço geogräfico considerāvel, sendo a utilização de agrotóxicos bastante difunaida. E possivel que esteja ocorrenco, ou que venha a ocorrer, uma migração de elementos nocivos a saúde para o lençol. freático alterando as condições naturais das águas subterrâneas. - quadro 02 mostra alguns dos produtos utilizados através da pulverização que ocorre de abril a dezembro e é feita uma vez por semana em cada plantio (informação verbal de produtores de morangos e rosas da região). Não dispomos de anālises de águas onde tenha sido considerado os elementos componentes dos agrotóxicos e pesticidas, portanto o risco permanece potencial.

\section{Uso Agrícola}

A qualidade das águas a serem utilizadas na agricultura deve ser analisada em conjunto com fatores agronômicos, tais como permeabilidade e tipo de solo, culturas a serem implantadas e métodos de irrigação, entre outros.

A maneira mais simples e direta de se obter indicaçōes da possibilidade de utilização de determinada água para a irrigação é verificando-se o 'risco de sódio'', referente a 


\begin{tabular}{|c|c|c|c|}
\hline PRODUTO & $\begin{array}{l}\text { CLASSE } \\
\text { TOXICOLOGICA }\end{array}$ & SINTOMAS & $\begin{array}{l}\text { ANIIDOTOT } \\
\text { TRATAMENTO }\end{array}$ \\
\hline $\begin{array}{l}\quad \text { TAMARON } \\
\text { - Inseticlda/Acaricida } \\
\text { - Organofos forado sis- } \\
\text { temico }\end{array}$ & $\begin{array}{c}\text { CLASSE I } \\
\text { - Altamente tóxico }\end{array}$ & $\begin{array}{l}\text { Fraqueza, dor de cabeça, opressäo } \\
\text { no pelto, visão turva, nauseas, } \\
\text { pupllas náo reativas, diarrélas } \\
\text { e cólicas abdominals }\end{array}$ & \multirow{8}{*}{$\begin{array}{l}\text { Nāo existe anti- } \\
\text { doto especifico. } \\
\text { Tratamento: } \\
\text { Sintomätico a } \\
\text { critério médico. }\end{array}$} \\
\hline $\begin{array}{l}\text { FOlidol } \\
\text { - Inseticida/Acaricida } \\
\text { - Organofos forado sis - } \\
\text { têmico }\end{array}$ & $\begin{array}{c}\text { CLASSE I } \\
\text { - Altamente töxico }\end{array}$ & $\begin{array}{l}\text { Fraqueza, dor de cabeça, opressäo } \\
\text { no peito, visão turva, nauseas, } \\
\text { pupilas näo reativas, diarrélas } \\
\text { e cólicas abdominals }\end{array}$ & \\
\hline $\begin{array}{l}\text { ORTHO - HAMIDOL } \\
\text { - Inseticida/Acaricida } \\
\text { - Organofos forado sis" } \\
\text { temico }\end{array}$ & $\begin{array}{l}\text { CLASSE I } \\
\text { - Altamente tóxico }\end{array}$ & $\begin{array}{l}\text { Fraqueza, dor de cabeça, opressāo } \\
\text { no peito, visäo turva, nauseas, } \\
\text { puplias näo reativas, diarréias } \\
\text { e cólicas abdominais }\end{array}$ & \\
\hline $\begin{array}{c}\text { VERMITEC } \\
\text { - Inseticida/Acarictda }\end{array}$ & $\begin{array}{l}\text { CLASSE I } \\
\text { - Altamente tóxico }\end{array}$ & $\begin{array}{l}\text { Mudança de coordenaçäo muscular, } \\
\text { tremores, etc. }\end{array}$ & \\
\hline $\begin{array}{c}\text { OMITE } \\
\text { - Acaricida }\end{array}$ & $\begin{array}{l}\text { CLASSE II } \\
\text { - Medianamente tó- } \\
\text { Xico }\end{array}$ & $\begin{array}{l}\text { Fadiga, diarrēia, manchas sangui- } \\
\text { nolentas na pele, sonolêncta e } \\
\text { depressão. }\end{array}$ & \\
\hline $\begin{array}{r}\text { SAPROL } \\
\text { - Fungicida }\end{array}$ & $\begin{aligned} & \text { CLASSE IX } \\
& \text { - Medianamente tó- } \\
& \text { Xico } \\
&\end{aligned}$ & $\begin{array}{l}\text { Fadiga, diarréia, manchas sangui- } \\
\text { nolentas na pele, sonolêncla e } \\
\text { depressäo. }\end{array}$ & \\
\hline $\begin{array}{l}\text { CERCONIL } \\
\text { - Fungicida }\end{array}$ & $\begin{array}{l}\text { CLASSE III } \\
\text { - Produto töxico }\end{array}$ & Dor de cabeça, naúseas, etc. & \\
\hline $\begin{aligned} & \text { MICROZOL } \\
= & \text { Fungicida/Acaricida }\end{aligned}$ & $\begin{array}{l}\text { CLASSE IV } \\
\text { - Pode ser tóxico }\end{array}$ & $\begin{array}{l}\text { Nauseas, vomitos, dor de cabeça, } \\
\text { diarrétas, etc. }\end{array}$ & \\
\hline
\end{tabular}

FONTE: Bulas dos produtos.

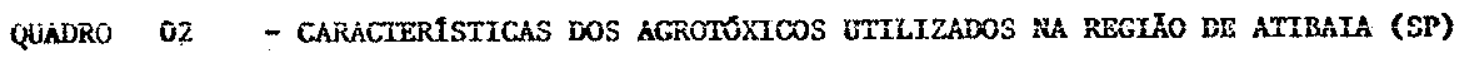


proporcão relativa de sódio para com outros cátions, e o 'perigo de salinidade"' A concentração de sōdio é importanté, pois ele. substitui o cálcio e se estiver err concentração excessiva irá reduzir a permeabilidade do solo (FREEZE \& CHERRY, 1979).

Os valores da Razão de Adsorção de Sódio (RAS) situamse entre 0,03 e 1,27, média de 0,42 , denotando um ' 'baixo risco de södio''. A condutividade elétrica situa-se abaixo de $300 \mu \mathrm{s} / \mathrm{cm}$, indicando 'baixo risco de salinidade'"

Outros elementos importantes para as plantas como o cálcio, magnésio, potássio e fósforo (EPSTEIN, 1975 in PrUCI, 1978 ) estão presentes.

Nenhum elemento está em concentraçäo excessiva e, desta forma, face aos elementos analisados não existe qualquer restrição destas äguas para o uso na agricultura.

\section{Uso Industrial}

A utilização das āguas nas indūstrias é regida por padrões que associam o tipo de atividade com os elementos que nesta encontram restrição. Padrões com limites de tolerāncia para vários tipos de indústrias são mostrados por TODD (1959), LOGAN (1965), CUSTÓIO \& LLAMAS (1976), MATTHESS (1982), DRISCOLL (1986) e SZIKSZAY (1986).

Alguns elementos das äguas subterrâneas estudadas estão em concentracões elevadas e impedem a utilização direta generalizada na área industrial, tais como:

TEXTEIS: o cálcio possui concentração acima do limite recomendado $(10 \mathrm{mg} / \mathrm{I})$ em seis amostras $(40 \%)$, sendo duas de pocos escavados e quatro de tubulares. 
CALDEIRAS: ăguas com alto conteúdo de sais, particularmente aqueles que influenciam na incrustação e. corrosão, devem ser evitadas. A concentração de silica entre 7,i e $4,0 \mathrm{mg} / 1$ está presente em 93,38 (14 amostras) a isto desaconselha a utilização direta dessas águas para caldeiras com pressão acima de $10 \mathrm{~kg} / \mathrm{cm}^{2}$ (LOGAN, 1965 ).

o bicarbonato varia de 26,2 a $109,8 \mathrm{mg} / 1$, quando 0 limite máximo aconselhável é de $20 \mathrm{mg} / 1$. 0 pH apresenta-se com valor abaixo de 7,2 em 93,38 das amostras analisadas e o limite minimo para utilização em caldeiras é de 8,0 (LOGAN, op. cit.).

A composição iônica da água não pode deixar de ser levada em consideração no dimensionamento da tela do poço, já que estas são bastante susceptiveis ao ataque eletrolítico e a incrustação.

As ãguas subterrâneas de Atibaia são, no geral, um pouco áciảs. o gás carbônico livre é uma medida de acidez e è comumente utilizada como indicador das propriedades corrosivas da água e, como regra aproximada, a concentração dele deve ser menor do que $10 \mathrm{mg} / 1$ em águas brandas e abaixo de $15 \mathrm{mg} / 1$ em àguas duras, caso se queria evitar sēria corrosão (LOGAN, op. cit.). Nas äguas analisadas, os valores encontrados situam-se entre 15,4 e $58,3 \mathrm{mg} / 1$.

Os outros elementos não possuem concentrações excessivas para o uso industrial. 


\section{4 - AVALiAçAo dAs obras de cAptaço}

\section{1 - Estado Atual da Tecnologia no Setor}

A exploração das águas subterrâneas na região em estudo é feita, basicamente, através de poços tubulares e escavados. Nas áreas de maiores altitudes (acima de $830 \mathrm{~m}$ ), as fontes de contato são exploradas e auxiliam frequentemente no abastecimento doméstico, escolas e fazendas.

Foram cadastradas 12 fontes e observa-se que somente em duas existem tanques de captação, sendo que no geral, a captação é feita atravēs de vasilhames. A mais conhecida delas ë denominada de "Mina do SAEE", situada a sudeste da área. o volume d'ãgua explorado, segundo informações verbais, é de 108 $\mathrm{m}^{3} / \mathrm{h}$, sendo esta água previamente tratada e posteriormente distribuida para pequenas comunidades e escolas dos bairros dos Alpes, Refúgio, Retiro das Fontes e Flaboyant.

\section{Poços Escavađos}

São também denominados de poços rasos, abertos, cacimbas ou caipiras, tendo sido cadastrados 157 deles em campo.

A população rural da região e significativa c na falta de un sistema ảe abastecimento d"āgua, ou de arenagens perenes que permitam uma captação superficial, o meio mais rápido para se conseguir água é através do poço escavado. Apesar da existência preponderante de rochas cristalinas, existe um manto de alteração com espessura de até 60 metros, o que facilita a construção desses poços.

Eles são construidos manualmente, no geral por uma dupla de homens denominados de "poceiros", e a profundidade oscila em função do rível estático, chegando a 32 metros, porém 
predominando o intervalo de 4,0 a 7,0 metros com 368 , sendo que 708 deles possuem no mäximo uma profundidade de 10 metros (Figura 26).

Devido ao fato dessas obras serem feitas por pessoas de baixa renda, não é comum a utilização de compressores ou bombas para a retirada d'água à medida que a escavação aprofunda e, consequentemente, ela tem que parar a poucos metros (em média entre 1,0 e $2,0 \mathrm{~m}$ ) abaixo do nivel estático. A análise da profundidade do poço e do nivel estático permitiu a elaboração da figura 27 , mostrando que existe uma coluna d'ägua que atinge atē 12,5 metros, predominando a altura entre 2,0 e 3,5 metros corn $38 \%$, seguida dos intervalos de 0,5 a $2,0 \mathrm{~m}$ e de 3,5 a 5,0 metros com $24,7 \&$ e 22,7 ; respectivamente.

A completação do poço é realizada com tubos prémoldados de concreto, com diâmetro de 1,0 metro e comprimento de 0,5 metros, ou com tijolos; porēm, o primeiro é mais utilizado em função do menor custo, maior rapidez de colocação e maior estabilidade da pareae do furo.

A água é retirada com balde lem mais de 90 \& dos pocos) com o auxilio de corda e roldana, ou através de bomba submersa.

Estás obrás são, no geral, isentas ue qualquer noxmá técnica de locação e completação. As bocas dos poços geralmente estão ao nivel do terreno, as tampas são mal colocadas e de 30408 das vezes elas não existem, não possuem lajes de proteção e é comum se observar a lavagem de roupas e outros afazeres domésticos sendo realizados à boca do poço. Além disto, existe uma distância mínima entre poco-fossa (entre 2,0-4,0 m) fazendo com que as águas subterrāneas estejam a mercē de uma poluição bacteriológica. 


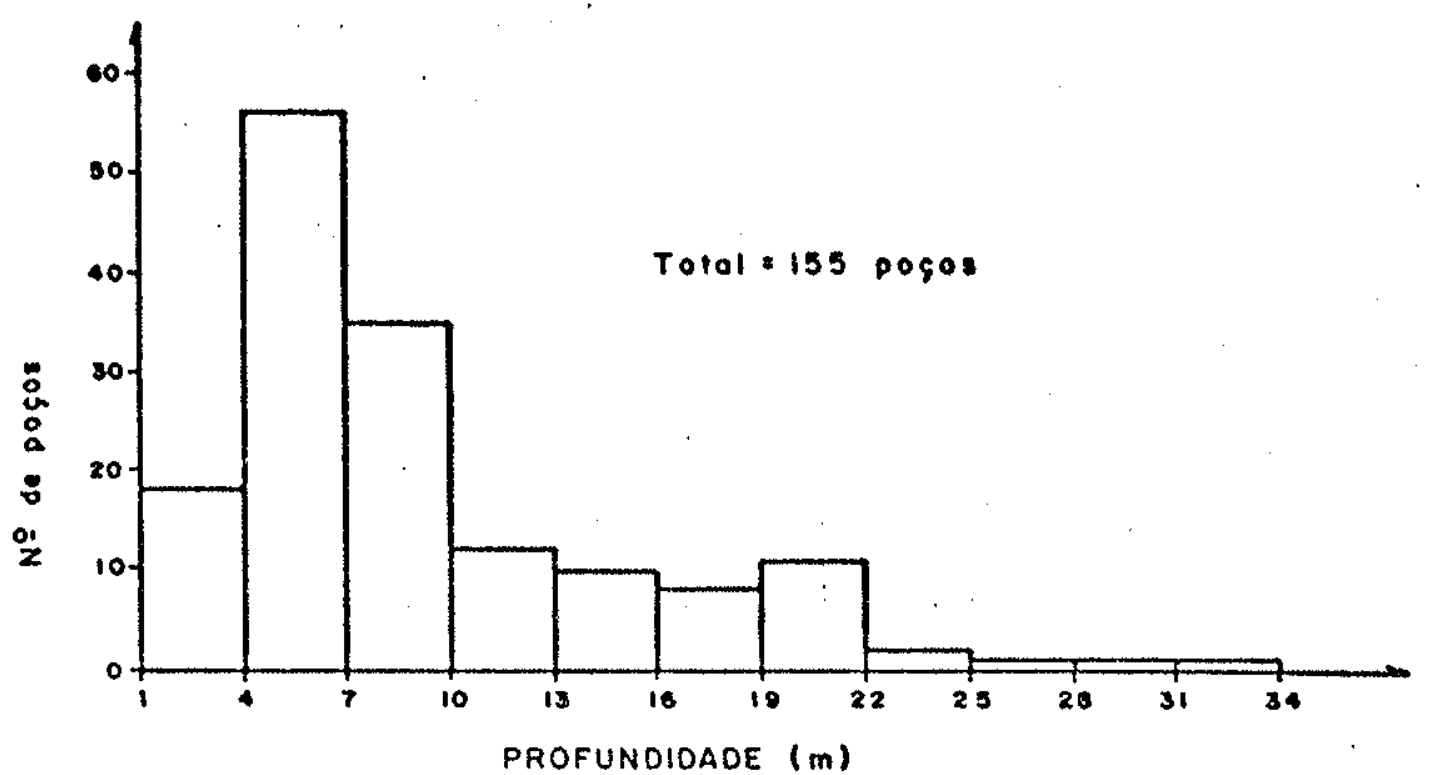

Figura 26 -Distribuiçāo de frequência das profundidades dos poços escavados - Atibaia (SP)

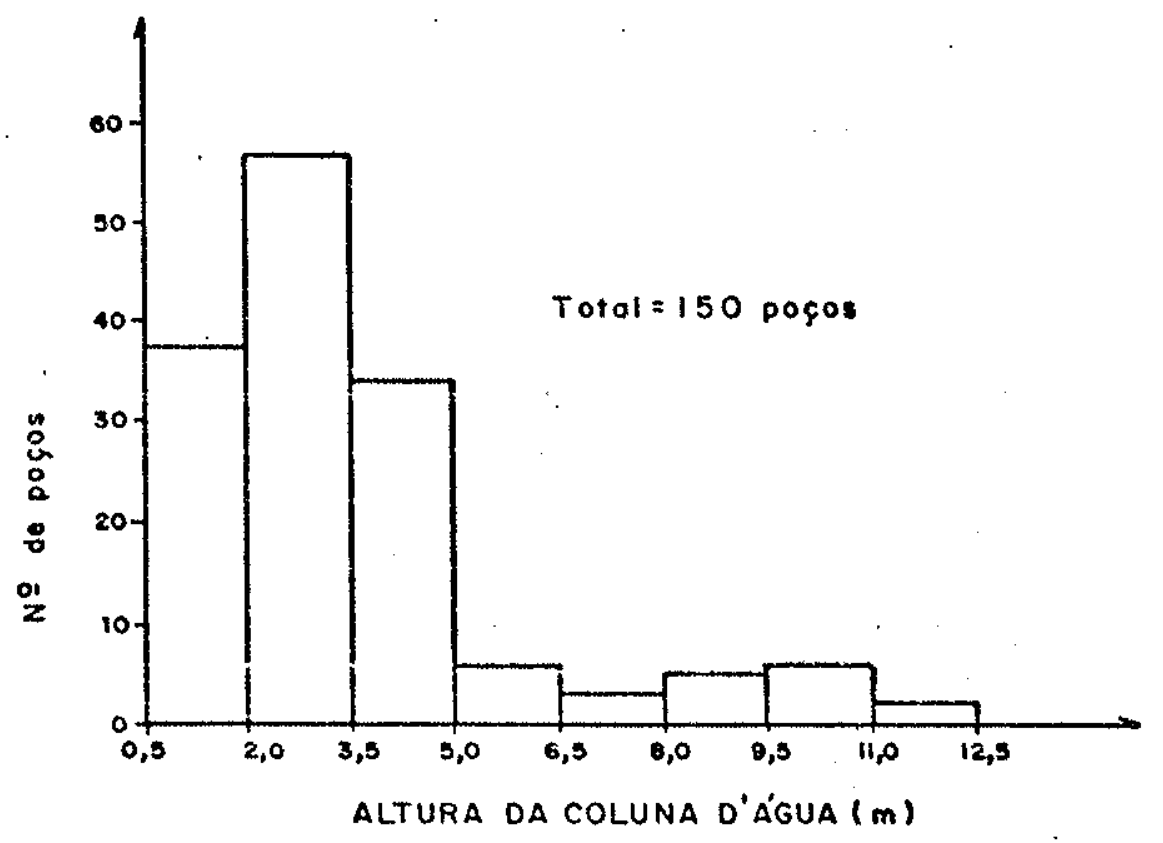

Figura 27 - Distribuiçāo de frequência das alturas das colunas d'água dos poços escavadosAtibaia (SP) 
Poços Tubulares

Foram cadastrados 79 poços, onde constam aqueles em exploração, desativados e abandonados. A situação atual observada na região é mostrada na tabela 08 . .

SITUAÇẼO ATUAL

NQ DE POÇOS

8

\begin{tabular}{|c|c|c|}
\hline Em exploração & 54 & 66,6 \\
\hline Desativados & 10 & 12,3 \\
\hline Abandonados & 01 & 1,2 \\
\hline Não observados & 14 & 19,9 \\
\hline TOTAL & 79 & 100 \\
\hline
\end{tabular}

TABELA 08 - SITUAÇO ATUAL DOS POCOS TUBULARES - ATIBAIA (SP).

Desta forma, observa-se que $66,6 \%$ dos poços da região estão em funcionamento. Os poços desativados representam aqueles que já estiveram em uso mas, por razões diversas, hoje estão parados; os abanđonađos são aqueĩes que nem sequer foram instalados e os não observados são os poços que foram localizados em campo mas não puderam ser observados, na maioria das vezes devido a ausência do proprietário. Porēm, todos estão plotados na base geológica e de pontos d'água (Anexo 03).

Com o crescente desenvolvimento da região e aumento do consumo d'ägua, as āguas subterrāneas são, a cada dia, mais exploradas. A figura 28 mostra que à partir de 1970 teve início o periodo de maior indice de perfuração de poços, 


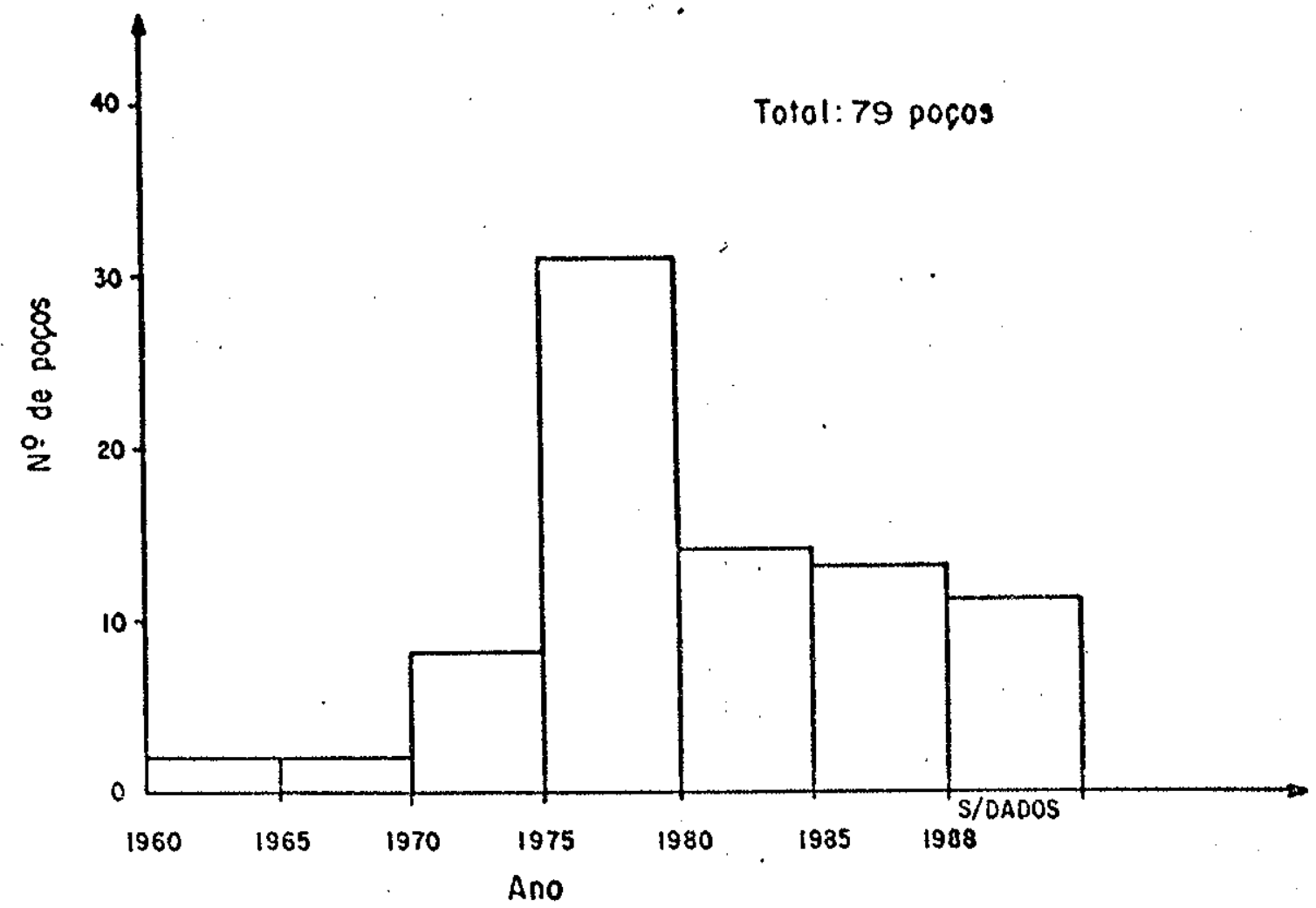

Figura 28 - Evolução temporal da perfuraçāo de poços fubulares na regiāo 
principalmente entre 1975-1980, intervalo de maior assentamento populacional e industrial da região.

Atualmente, as águas subterrâneas são utilizadas para múltiplos fins, como mostra a tabela 09 . Observa-se que 50,98 dos poços são utilizados exclusivamente para abastecimento doméstico e que a demanda no campo industrial é significativa com 18,98 .

USO

NQ DE POÇOS

8

\begin{tabular}{lcc}
\hline & & \\
Doméstico & 27 & 50,9 \\
Indüstrial & 10 & 18,9 \\
Doméstico + hara + granja & 08 & 15,0 \\
Recreaço & 06 & 11,4 \\
Floricultura & 01 & 1,9 \\
Abastecimento Püblico & 01 & 1,9 \\
& & 100 \\
\hline
\end{tabular}

TABELA 09 - UTILIZAÇÃo DAS AGUAS SUBTERRÃNEAS NA REGIX̃o DE ATtBATA - SE

Com o aumento da procura de água subterrānea, o nümero de empresas operando com perfuração de poços cresceu significamente. A análise das fichas-técnicas com informações sobre a forma de perfuração, permitiu elaborar a tabela 10 . onde se constata o grande leque de empresas atuando na região de Atibaia, com a Jundsondas Poços Artesianos Ltda e Air lift Ina. Com. S.A. sendo as principais concorrentes, com 20,48 e $16,7 \%$, respectivamente, dos poços perfurados. 
Além destas, existem também a Saiāgua, Rođágua, Bravo, Hidrogesp, Perfurat, Alfa Tokio, Aquater e Iamagata, cada uma tendo perfurado um poço na área estudada.

EMPRESA

NQ DE POÇOS

8

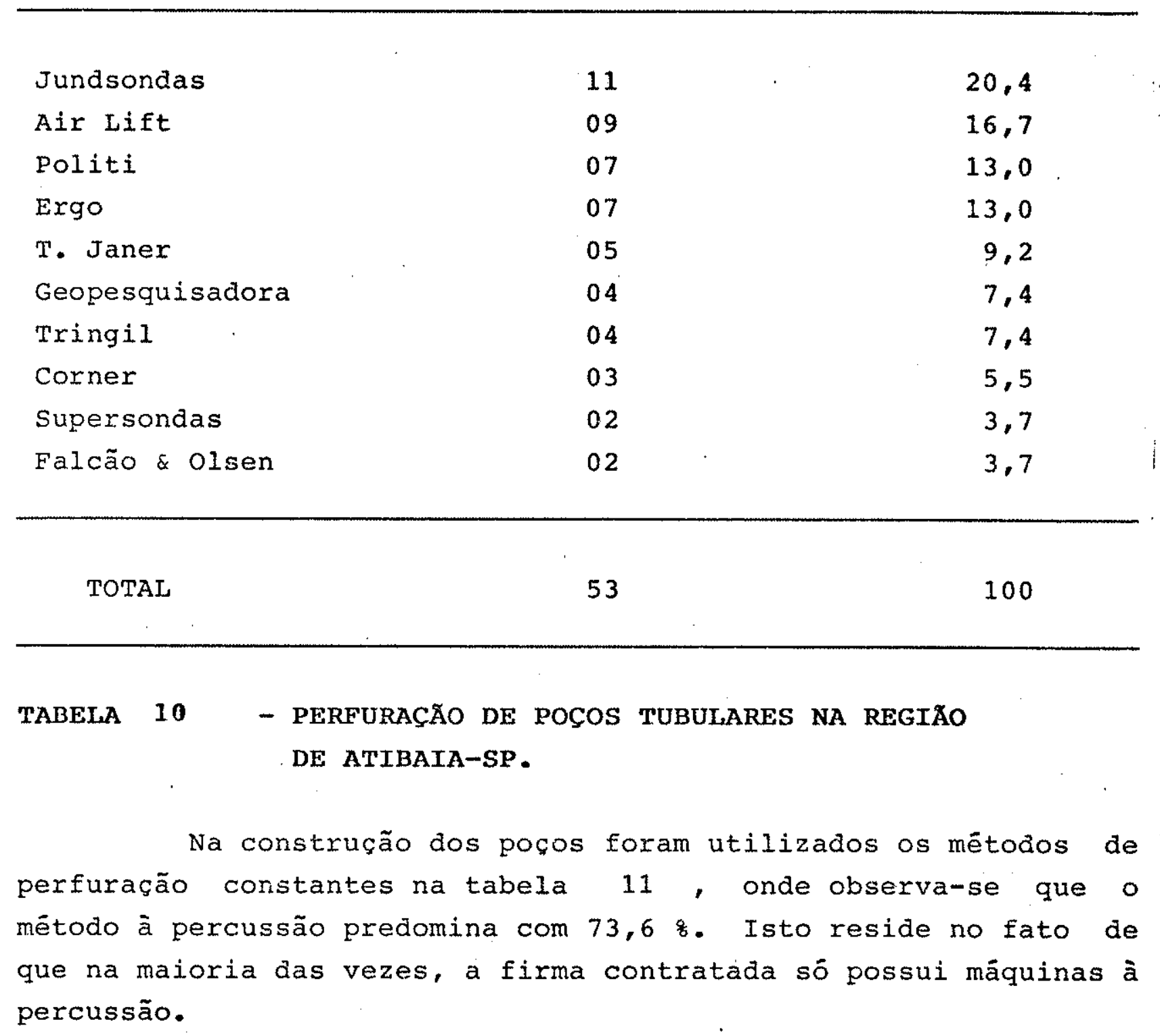


METODO DE PERFURACAO
No DE POCOS

8

\begin{tabular}{lrr}
\hline & 39 & 73,6 \\
Percussão & 11 & 20,8 \\
Roto-percursor & 03 & 5,6 \\
Rotativo & & 100 \\
\hline$\quad$ TOTAL & 53 & \\
\hline
\end{tabular}

TABELA 11 - MÉTODOS DE PERFURAC̆̃O DE POÇOS TUBULARES UTILIZADOS NA REGIX̃ DE ATIBAIA-SP.

o mētodo de perfuração mais rápido é o roto-percursor, cujos poços (com profundidade de até $343 \mathrm{~m}$ ) são perfurados dentro de um intervalo de poucas horas (24 a 72 horas), com um rendimento de perfuração médio de $100-150 \mathrm{~m} / \mathrm{dia}$.

A medida que está sendo realizada a perfuração, as litologias vão sendo amostradas e descritas para se compor a coluna geológica local. A maioria das empresas procura fazer uma descrição das litologias, muitas vezes extremamente reduzida, porêm hã ocasiões em que se torna dificil diferenciar as coberturas sedimentares das litologias do manto de alteração.

- diãmetro de perfuração do poço pode, ou não, ser constante, em função das conđições geológicas locais e do fator econômico. As tabelas 12 e. 13 mostram, respectivamente, o número de diâmetros e os diâmetros utilizados na perfuração dos poços na área em estudo. 


$\begin{array}{lrr}01 & 02 & 5,3 \\ 02 & 12 & 31,6 \\ 03 & 15 & 39,4 \\ 04 & 06 & 15,8 \\ 05 & 02 & 5,3 \\ 06 & 01 & 2,6\end{array}$

TOTAL

TABELA 12 - NUMERO DE DIAMETROS UTILTZADOS NA PERFURAÇAO DE POÇOS TUBULARES. - ATIBATA (SP) -

Verifica-se que foram utilizados até 6 diâmetros, com predominância do uso de $3(39,48)$ ou $2(31,6$ \%) tipos. 
DIAMETROS

NQ DE POÇOS

8

\begin{tabular}{|c|c|c|}
\hline 6 & 1 & 2,6 \\
\hline 8 & 1 & 2,6 \\
\hline $8+6$ & 1 & 2,6 \\
\hline $81 / 2+6$ & 4 & 10,4 \\
\hline $81 / 4+6$ & 1 & 2,6 \\
\hline $10+6$ & 1 & 2,6 \\
\hline $12+6$ & 2 & 5,2 \\
\hline $121 / 2+6$ & 1 & 2,6 \\
\hline $12+8$ & 2 & 5,2 \\
\hline $10+8+6$ & 6 & 15,6 \\
\hline $10+85 / 8+6$ & 1 & 2,6 \\
\hline $12+8+6$ & 2 & 5,2 \\
\hline $121 / 4+8+6$ & 1 & 2,6 \\
\hline $12+91 / 2+6$ & 1 & 2,6 \\
\hline $14+10+6$ & 1 & 2,6 \\
\hline $15+8+6$ & 1 & 2,6 \\
\hline $16+8+6$ & 1 & 2,6 \\
\hline $16+14+6$ & 1 & 2,6 \\
\hline $10+8+7+6$ & 1 & 2,6 \\
\hline $12+10+8+6$ & 2 & 5,2 \\
\hline $14+12+8+6$ & 2 & 5,2 \\
\hline $14+12+10+6$ & 1 & 2,6 \\
\hline $14+12+10+8+6$ & 1 & 2,6 \\
\hline $16+13+10+8+6$ & 1 & 2,6 \\
\hline $20+15+121 / 4+10+8+6$ & 1 & 2,6 \\
\hline TOTAL & 38 & 100,0 \\
\hline
\end{tabular}

TABELA 13 - DIÃMETROS UTILTZADOS NA PERFURAÇ̃o DE POÇOS TUBULARES NA REGIÃO DE ATIBAIA - SP. 
Observa-se que em 94,7 \& dos poços com registro de perfuração foram utilizados mais de um diâmetro. Invariavelmente, todas atravessam o manto de intemperismo e terminam na rocha sã, e o diâmetro mais utilizado na fase terminal é $\circ$ de $6 "(94,48)$, seguido pelo de $8 "(5,6$ 8). 0 diâmetro final é o diâmetro útil da câmara de bombeamento.

- revestimento do poço tem por função básica evitar o desmoronamento das paredes do furo e, na medida do possivel, impedir a entrada de águas superficiais ou de infiltraçōes rasas, ou de qualquer outrofluido, para o aquifero. Na região de Atibaia ele é restrito no manto de intemperismo, penetrando na rocha sã (em média de 1,0 e $2,0 \mathrm{~m}$ ) somente para cravar e dar estabilidade à tubulação.

Observa-se que os poços com um revestimento predominam com 80,6 , seguido daqueles que possuem dois tipos $(17,88)$, como ressalta a tabela 14 . Referente ao tipo de tubo utilizado, as informações procedentes de 33 fichas técnicas mostram que os tubos de aço galvanizado predominam em $78,8 \%$ dos poços, enquanto que em 18 \& foram utilizados tubos de aço preto Iiso e um poco foi revestido com tubos de PVC. Nas fichas não constam dados de espessuras dos tubos.

o filtro, ou tela, é um elemento importante para o poço Iocado em rochas friáveis. Ele tem a função de suportar a pressão exercida pelas camadas adjacentes e permitir a passagem mäxima de água, sem que haja penetração de particulas arenosas para o interior da obra. 


\begin{tabular}{lrr}
\hline 6 & 31 & 51,0 \\
8 & 15 & 24,7 \\
10 & 1 & 1,6 \\
12 & 2 & 3,3 \\
$91 / 2+6$ & 1 & 1,6 \\
$10+6$ & 1 & 1,6 \\
$101 / 4+6$ & 1 & 1,6 \\
$12+6$ & 4 & 6,6 \\
$12+3 / 4+6$ & 1 & 1,6 \\
$12+8$ & 1 & 1,6 \\
$14+6$ & 1 & 1,6 \\
$14+8$ & 1 & 1,6 \\
$12+8+6$ & 1 & 1,6 \\
\hline & & 100,0 \\
\hline
\end{tabular}

TABELA 14 - DIÃMETROS DE REVESTIMENTO dOS POÇOS TUBULARES ATIBATA (SP)

Nos poços da ärea, ofiltro fica restrito às zonas intemperizadas e/ou muito fraturadas, sendo que somente seis fichas acusam o uso de filtro e todos posicionados no manto de alteracão, sem que conste o tipo ou o material de fabricaça do filtro.

Quanto ao pré-filtro, existem referências em dez fichas de poços quanto a utilização do pré-filtro artificial do tipo Jacarei (areias com granulometria de 2 a $3 \mathrm{~mm}$, da região de Jacarei - Vale do paraíba). 
No geral não existe nenhum estudo de reconhecimento hidrogeológico direto (atravès de sondagens mecânicas de reconhecimento) ou indireto (através de métodos geofísicos) antes da locação e perfuração dos poços tubulares na região estudada.

As profundidades dos poços são extremamente variáveis, indo de 36 a 343 metros (Figura 29), com o intervalo de 100 a 150 metros predominando com $37 \%$. Ressalta-se que a perfuração no manto de intemperismo pode alcançar 60 metros.

Relacionado ao equipamento de bombeamento, observa-se que de 49 poços, em 75,5 \& são instaladas bombas submersas, 228 possuem bombas injetoras e somente um poço é explorado através de compressor a ar comprimido. Não existe uma correlação entre tipo de equipamento e vazão instalada.

Sobre o regime de exploração dos poços, existe uma variação desde 1,0 até 20,0 horas/dia em função do uso destinado, porém 80 \% deles são operados somente horas algumas por dia (2 5 horas).

A cimentação, a laje de proteção e a tampa do poço são aspectos importantes no que diz respeito a proteção sanitária.

A cimentação procura assegurar maior proteção sanitäria, impedindo infiltrações de fluidos superficiais ao longo do espaco anular ov da parte externa do tubo de revestimento, ou, se necessäria, isclando formações aquiferas que contenham ägua de má qualidade. Das fichas dos poços cadastrados, somente em seis existem referências a este processo.

A laje de proteção, como ressalta o pröprio nome, protege a obra e, consequentemente, $\circ$ aquifero contra a infiltraça direta de águas superficiais ou de quaisquer outros fluidos. No geral, os poços da região não a possuem e, quando esta existe, não obedece o que preceitua a ABNT (1977) como mostra a Foto 01 (página 13). 


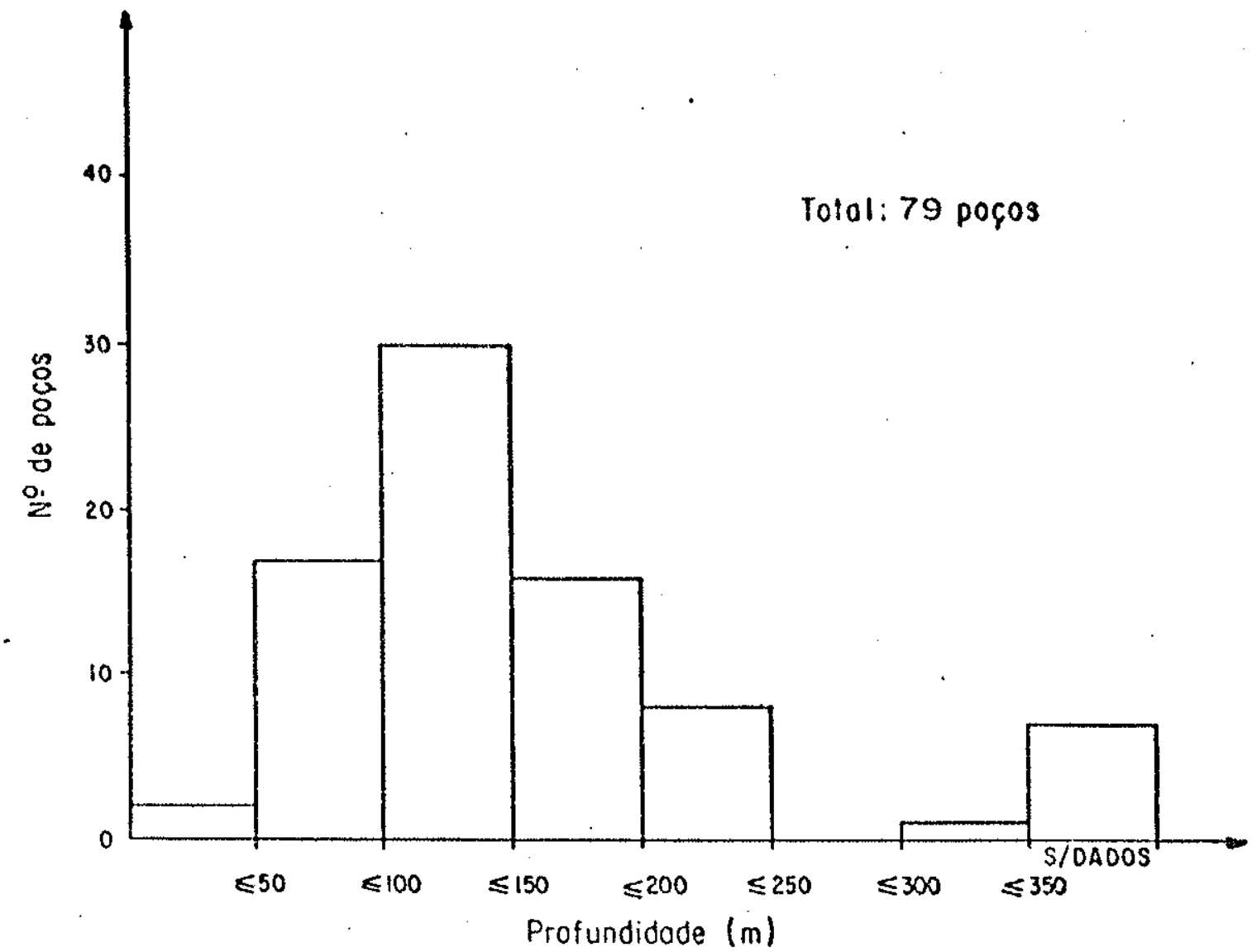

Figura 29 - Distribuiçāo de frequēncio das profun didades dos pocos tubulares 
Apōs a instalação do equipamento de bombeamento, a boca do poço deve ser protegida por uma tampa, geralmente de ferro, fixada por qualquer processo, para evitar qualquer ato depredativo contra o interior da obra e, consequentemente, evitar uma ação nociva às águas subterrâneas. Na região em estudo, 828 do poços tem esta tampa aparafusada ou soldada diretamente ao revestimento e em 18 \& ela está mal fixada, deslocada da posiçäo ideal. 


\section{2 - Considerações e Recomendações}

As considerações e recomendações ora realizadas são baseadas no conhecimento da situação de locação, perfuração e completação de poços na região de Atibaia, através do cadastro de 79 pocos tubulares e 157 poços escavados.

\section{Poços Escavados}

A quantidade significativa desses pocos na ārea mostra a importância que eles representam para a população, principalmente na zona rural onde não existe nenhum sistema de abastecimento de ägua.

- volume estocado no poço supre normalmente a demanda doméstica requerida, no geral sempre abaixo de $2,0 \mathrm{~m}^{3} / \mathrm{dia}$. Os testes de bombeamento com duraça de 4 horas realizados em cacimbas da região corroboram esta afirmação, mostrando que elas possuem vazões da ordem de $1,0 \mathrm{~m}^{3} / \mathrm{h}$, satisfazendo, desta forma, 0 consumo de água a nível doméstico.

- custo dessas obras, em comparaça com o dos poços tubulares, é irrisório e isto faz com que elas sejam bastantes difundidas e utilizadas. comum a existência de cacimbas ao lado do poso tubular, as quais muitas vezes funcionam como fonte complementar de abastecimento a'água, a exemplo do que acontece no sitio Santinha (poço tubuiar no 22 e cacimbas ne 71/72) e chäcara sion (poço tubular no 21 e cacimba ne 157).

Os maiores problemas encontrados nessas obras estão relacionados a locação, tampa e laje de proteção do poço.

A comunidade rural além de não possuir um sistema de abastecimento d'água, tambēm não possui um sistema de esgoto. 
Para o primeiro, a cacimba é a alternativa mais utilizada e, para - segundo, a fossa é o meio mais usual de disposicão de efluentes.

Como normalmente o espaço físico è limitado, a distância entre a fossa e a cacimba é minima, dificilmente obedecendo o espaço de 15 a 30 metros sugerido pela Associação Brasileira de Normas Técnicas - ABNT (1977) e, consequentemente, existindo o risco potencial de uma poluiçäo bacteriológica para as águas subterrâneas. DUARTE \& KANEHISA (1986) enfocam muito bem a problemática existente entre pocos rasos e fossas, com exemplos reais e avaliação técníca através das normas existentes.

No geral, de 30 a 40 \& das cacimbas da região não possuem a tampa de proteção (ou de vedação) e quase sempre que a possuem, ela é constituída de pedaços de madeira que ficam mal assentados, deslocados, criando espaços que permitem a introdução de objetos e até mesmo de pequenos animais e insetos para dentro do poço, colocando em risco a qualidade da água.

o recomenđāvel neste caso, é que se utilize tampas prémoldadas de concreto, porém não fixas permitindo o deslocamento quando necessário, com um espaço central aberto para permitir a instalação da bomba ou descida de baldes para retirada d'água. Quando se utilizar tampa de madeira, é importante que ela seja feita de madeira sólida e que abranja totalmente a boca do poço.

A boca do poço deve ser elevada acima da superficie, no mínimo $50 \mathrm{~cm}$, evitando infiltração de águas superficiais e acidentes maiores, como a queda de animais.

Não existe praticamente nenhum poço que possua laje de protecão, salvo raríssimas exceções, favorecenđo a infiltração direta de águas pluviais ou de limpeza, já que inúmeras vezes se verifica a lavagem de roupas e outros afazeres domésticos à boca do poço. 
E necessãria a laje de proteção feita de concreto, fundida no local, e distribuída simetricamente em tôrno do poço. E aconselhável que possua uma espessura mínima de $10 \mathrm{~cm}$, abranja uma distância minima de 1,0 metro à partir da parede da obra e que possua uma pequena declividade $(1-28)$ permitindo que a água que ali circule, escoe para fora do poço.

Por falta de esclarecimentos, muitas vezes as cacimbas abandonadas são utilizadas como depósitos de lixo e até mesmo como fossas. E imprescindivel que exista um programa de conscientização e fiscalização para se evitar estes atos que colocam em risco os aspectos qualitativos das águas subterrâneas pois, ao mesmo tempo em que são poluidas, são tambêm exploradas para abastecimento doméstico.

Apesar da condutividade hidräulica do manto de aiteração ser baixa $\left(10^{-3}\right.$ a $\left.10^{-5} \mathrm{~cm} / \mathrm{s}\right)$, ele possui espessuras que chegam a 60 metros, predominando 0 intervalo de $20-40 \mathrm{~m}(68$ ( $)$ e isto faz com que a transmissividade seja considerável, 0 que nos leva a recomendar que ele seja muito mais explorado visando a captação das águas subterrâneas.

Quando for requerida maiores demandas, outros tipos de captações podem ser feitas como, por exemplo, poços amazonas e coletores (com ponteiras ou drenos radiais). Todos são construidos manualmente, com utilização de tecnologia e acompanhamento técnico especializado, e com espectativas de vazões de até $5 \mathrm{~m}^{3} / \mathrm{h}$ para o poço amazonas e maiores do que $20 \mathrm{~m}^{3} / \mathrm{h}$ para os pocos coletores.

- Japão e a Africa vêm utilizando poços coletores, no embasamento cristalino com manto de intemperismo, com grande sucesso (WRIGTH \& HERBERT, 1985). Em Zimbabwe e Sri Lanka (Africa) foram construidos posos com profundidade de 10 a $14 \mathrm{~m}$, 
diâmetros de $3 \mathrm{~m}$, com 5 ou 6 ponteixas radiais de aproximadamente $30 \mathrm{~m}$ cada, lâmina d'água de 5 a $10 \mathrm{~m}$ e geraram vazões de 5,4 a 13 $\mathrm{m}^{3} / \mathrm{h}$ por ponteira.

\section{Poços Tubulares}

Um poço é uma obra de engenharia construida à partir de um projeto básico que envolve o conhecimento das caracteristicas hiđorogeológicas e da qualidade da água. A construção da obra, associada a uma criteriosa seleção do material a ser empregada, tem por objetivo o bom funcionamento mecânico, maior vida útil do poço e que permita a exploração das águas subterrâneas a uma razão custo "versus" benefício considerável.

Basicamente, para construir um poço tubular tem que se levar em consideração os aspectos técnicos de locação, método de perfuração, diâmetro(s) de perfuração, revestimento(s), filtros, pré-filtro, profundidade e desenvolvimento da obra.

Quardo se trata da locação do poço em meio urbano não dá para se estabelecer um critério técnico em virtude dá escassez de espaço, e esta fica vinculada estritamente a localização da demanda. E o que acontece em $90 \%$ dos casos na região de Atibaia, a exemplo de quase todas as fábricas e chácaras de recreio.

Porêm, existem ocasiões em que predomina o desconhecimento do aspecto técnico e a locação é feita em locais não desejáveis, a exemplo dos poços perfurados em ảivisores d'água (sítio Janaina, poços no 9/10; sitio Caioçara, poço no 16; Loteamento Santa Maria, poço no 28), resultando em grandes profundidades (acima de $200 \mathrm{~m}$ ) e ínfimas vazões $(0,25$ - 1,6 $\left.\mathrm{m}^{3} / \mathrm{h}\right)$, sempre muito abaixo do desejado; além desses, existem também poços situados muito próximos a fossas e lagoas.

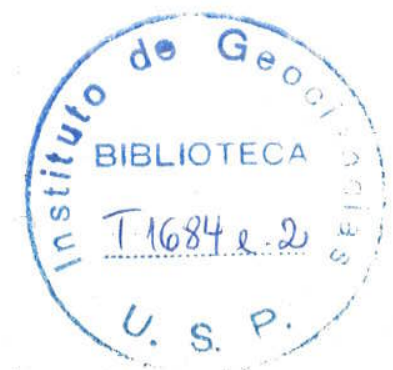


o recomendável é se fazer uma avaliação hidrogeológica prévia para se definir o melhor local para a perfuração do poço. Pertinente a distancia em que ele deverá ficar das obras e instalações em geral, a ABNT (1977) sugere que "o ponto preciso de perfuração do poço deverá ficar afastado de obras e instalações, com as seguintes distāncias minimas em planta:

a) Prēdios e estruturas em geral, escavacões, galerias e canais: $5 \mathrm{~m}$;

b) fossas sépticas, canalizações de esgoto, unidade para tratamento de esgoto: $15 \mathrm{~m}$;

c) privadas secas, fossas negras, linhas de irrigação subsuperficial, lagoas e valos de oxidação, esterqueira: $30 \mathrm{~m}$."

Um aspecto que deverá ser observado na locação é o posicionamento do poço em relação as culturas de morango e rosas, altamente difundidas na região. Muitas vezes ela é feita muito próximo à plantação, ou abaixo topọraficamente, ficando o poço exposto a migração de pesticidas e agrotóxicos utilizados na irrigação.

Um aspecto importante durante a perfuração do poco è a amostragem das litologias, pois este procedimento permite a composição ảa coluna geológica local, estabelecimento de posicionamento dos filtros, verifica a necessidade, e dimensionamento da granulometria do pré-filtro artificial e diz o momento em que se deve parar a perfuração.

Dos métodos empregados, o percussivo permite a obtenção de amostras bastante representativas, enquanto que o rotativo e, principalmente, o roto-percurssor exigem um redobrado cuidado em função da velocidade de perfuracão. 
o projeto do poco deve estimar o diāmetro e a espessura da parede dos tubos de revestimento, considerando-se o diâmetro da perfuração, vazão prevista e diâmetro útil da bomba a ser instalada. A anālise físico-química da água a ser explorada é sempre aconselhável, para a escolha do material de revestimento e equipamento de bombeamento.

Observa-se que a vazão explorada na região é geralmente inferior a $10 \mathrm{~m}^{3} / \mathrm{h}$, portanto, compativel com o diāmetro final de 6" que predomina com 51 . Acima deste, na extração de ãgua por meio de bombas submersas ou bombas de eixo prolongado, existirá um superdimensionamento do diâmetro útil da câmara de bombeamento do poço, pois será prevista uma vazão explorável superior a $40 \mathrm{~m}^{3} / \mathrm{h}$ (ABNT, 1977).

Comumente, o projeto de poços tubulares na área de estudo não prevê a utilização do aquífero manto de intemperismo, sendo ele totalmente revestido. o raciocinio utilizado é de que estas águas não se prestam ao uso, principalmente ao consumo humano.

Porêm, verifica-se o efeito "cachoeira" nos poços, mostrando que existe contribuição das ãguas do manto de intemperismo para o poço. Ainda, nos piezômetros multiniveis instalados somente no manto de alteração, monitorando pocos tubulares, constatou-se que existe a transferência efetiva das águas subterrâneas do manto para o meio fraturado e, desta forma, fica bastante claro que o revestimento utilizado não evita a exploração das águas do manto de intemperismo.

Portanto, recomenda-se que o uso do revestimento não seja feito indiferentemente, mas que haja uma descricão geológica das amostras visando a colocacão de filtros nos niveis mais permeãveis, propiciando, consequentemente, maiores vazões. Como 
- material intemperizado é bastante fino, impossibilitando a formação de um pré-filtro natural, é recomendāvel a utilização de pré-filtro artificial.

As maiores profundidades dos pocos da região estão associadas ao desconhecimento das condições hidrogeológicas locais e a crença de que quanto maior a profundidade, maior a possibilidade deste ter boa vazão. Exemplo desse pensamento são os poços com profundidades entre 200 a 350 metros perfurados em divisores d'água, que no final apresentaram vazões abaixo de 1,7 $\mathrm{m}^{3} / \mathrm{h}$ ou são praticamente secos.

Observa-se que 80,5 dos pocos foram perfurados em cotas abaixo de $810 \mathrm{~m}$ e possuem profundidades inferiores a 180 metros. Como as fraturas (entrada d'ägua) encontradas localizamse predominantemente no intervalo de 24 a $102 \mathrm{~m}(62 \%)$, é recomendável que a perfuração de poços na região, sem um prévio estudo hidrogeológico, seja realizada em altitudes inferiores a 810 metros e que a profundidade não ultrapasse 150 metros.

A predominância do uso de bombas submersas $(75,5.8)$ é função do menor custo de instalação, menor consumo de energia e a extrema valia no caso dos grandes rebaixamentos observados nos poços estudados.

A ABNT (op cit.) preconjza que todo poco deverá ser dotado de uma laje de proteção com área mínima de $3 \mathrm{~m}^{2}$, espessura não inferior a $10 \mathrm{~cm}$ e capaz de suportar, sem apresentar trincas, os equipamentos que sobre a mesma foram instalados. Na região observa-se que raramente existe esta proteção e isto facilita a infiltraçăo de águas superficiais e, portanto, contribui para a poluição das àguas subterrâneas. E importante que esta laje seja assentada, minimizando o risco de infiltração de äguas sujas para o aquifero. 
Os pocos desativados ou abandonados geralmente são vistos com negligência e não possuem qualquer sistema de proteção (Foto 05), deixando um sistema de veiculação direta entre superfície e águas subterrãneas. Isto faz com que o aquífero fique a mercê da atitude de cada um, podendo o furo não ser notado ou ser um incentivo a utilização como depōsito de lixo, causando um dano irreparável ao potencial hidrico subterrâneo. 


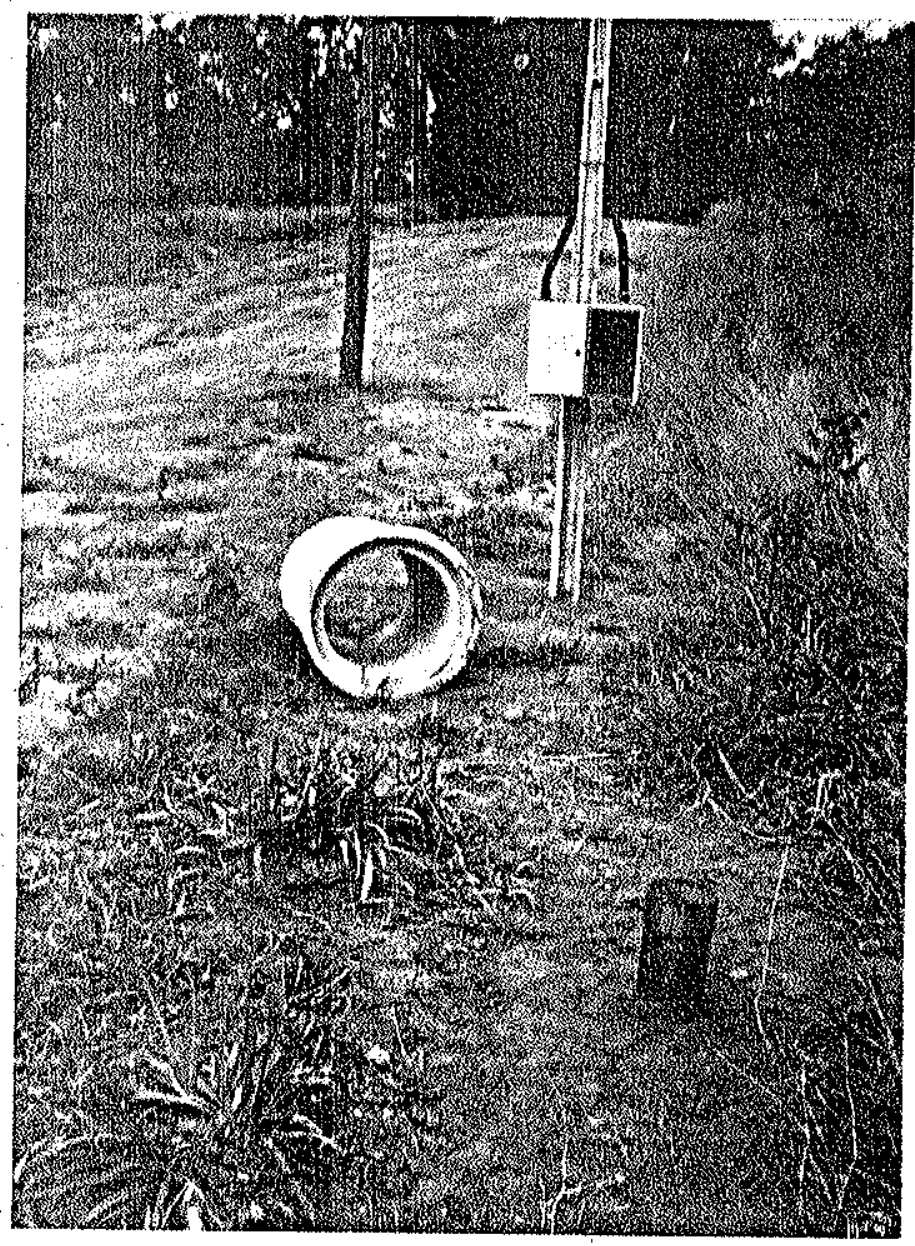

Foro 05-Poco tubular abandonado, sem nenhum sistema de proteç̃o, com pröfundidade de 180 metros e vazão de $0,3 \mathrm{~m}^{3} / \mathrm{h}$. Estä situado em divisor d'água com altitude de 860 metros.

LOCAL - Loteamento Santa Maria - Atibaia (SP). 


\section{5 - PRoposiçAo de metodologia dE ESTUdo}

A pesquisa hidrogeológica em terrenos cristalinos com manto de intemperismo vem sendo cada vez mais necessária à medida em que o espaço físico è ocupado e cresce a demanda híarica subterrânea.

Porém, os trabalhos desenvolvidos ainda se resentem de uma metodologia de estudo vinculada aos aspectos especificos deste contexto onde, muitas vezes, as diretrizes adotadas provém de estudos em áreas diferentes, embora precambrianas, a exemplo do nordeste brasileiro onde as condições climáticas não propiciam condições de desenvolvimento do manto de alteração.

Desta forma, procurando contribuir para a pesquisa hidrogeológica e baseando-se no trabalho ora realizado, é que propõe--se uma metodologia de estudo hidrogeológico para este meio, obedecendo a seguinte sequência:

\section{a) Cadastro de informações}

Esta fase busca integrar as informações existentes sobre a área de estudo, realizando o levantamento do acêrvo bibliográfico para compreender os aspectos fisio-climáticos, geológicos, estruturais e hidrogeológicos.

* necessária a aquisição de mapas planialtimétricos, geológicos e hidrogeológicos existentes, em escalas diversas, a fim de se fazer a integração para o estudo regional e local, definindo a escala de trabalho.

- cadastro de poços tubulares nos örgãos públicos e empresas particulares que operam com perfuração é imprescindivel. Neste cadastro deve constar dados de nivel estático, nível dinâmico, vazão, profundidade do poç, características 
hidrodinâmicas do aquífero, perfil litológico, dados construtivos e localização da obra de captação, bem como as análises físicoquímicas e bacteriológicas.

Fotografias aëreas, ou imagens de satélite, em escalas compativeis com o trabalho devem ser adquiridas, pois a interpretação deste material possibilitarä condições vantajosas para o desenvolvimento do estudo.

\section{b) Interpretação fotogeológica e etapas de campo}

Em virtude das suas características litológicas, o cristalino possui baixissima porosidade intergranular e a pesquisa hidrogeolọgica restringe-se às zonas fraturadas. Porém, sob o clima úmido esta configuração é alterada, pois as condiçöes climáticas favorecem o desenvolvimento de um manto de intemperismo significante, com porosidade intergranular, capaz de funcionar como meio aquifero poroso.

Diversos trabalhos mostram a importância da intexpretação fotogeológica no estudo de águas subterrâneas em regiões cristalinas, a exemplo de SETZER (1964, 1966) e GONÇALVES (1978), sendo que este método visa, basicamente, mapear falhas e/ou fraturas, fatores essenciais para a existência de água neste contexto. Em regióes com manto de intemperismo este trabalho é dificultado, pois ele mascara estas estruturas, sendo necessáxia fases de campo para confirmação do mapa foto-interpretado e levantamento de novos dados.

As seguintes etapas de campo devem ser programadas:

1a) Geologia de Campo;

2a) Cadastro de pontos d'água; 
33) Coleta de amostras de águas subterrâneas para anälises físico-quimícas e, se necessäria, bacteriológicas;

4 a) Sondagens (diretas e indiretas) para o estudo do manto de intemperismo e meio fraturado.

\section{Geologia de Campo}

Nesta fase deverá ser realizada a verificação das informações geológicas contidas no mapa elaborado em escritório, à partir dos mapas cadastrados e da interpretaça fotogeológica.

E aconselhävel tomar-se medidas de fraturas, sendo estas realizadas em afloramentos diversos, por litologia, se caracterizando os graus de abertura, interconecção e tipo de preenchimento das fraturas, caso exista. Estes dados facilitarão - entendimento do fluxo subterrâneo e o.trabalho de locação de poços.

o fraturamento não é condição exclusiva para a existência de ägua. Situaçöes diversas são encontradas em perfurações de poços, onde muitas vezes se tem um grande número de fraturas, porém a vazão é praticamente nula face a inexistência de zonas de alimentação para o meio fraturado, como ilustra a figura 30 , onde em principio existe um poço no cristalino são, com vazão insignificante ou mesmo sêco, e gradativamente vai se observando fraturamento, interconecção de fraturas e zona de recarga para que, finalmente, se tenha a melhor condição para a locạço do poço.

Os aspectos litológicos não poidem ser negligenciados, pois servirão de suporte básico para explicacão do perfil de alteração, quando estudados sob o ponto de vista mineralógico e correlacionados a série de estabilidade de GoldICH (1938) e 
(1)

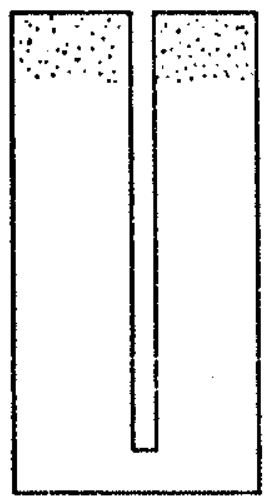

(5)

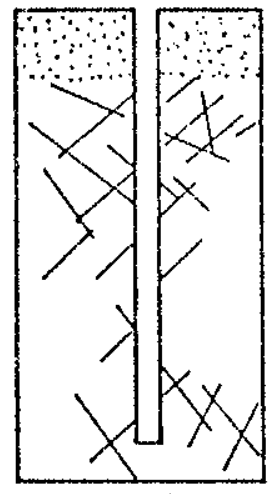

(7)

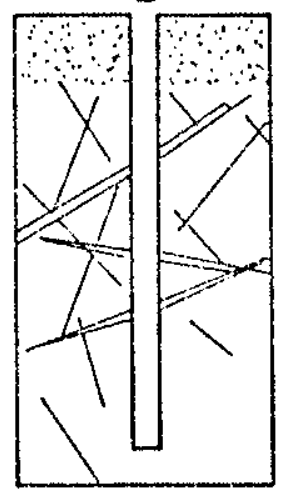

(8)

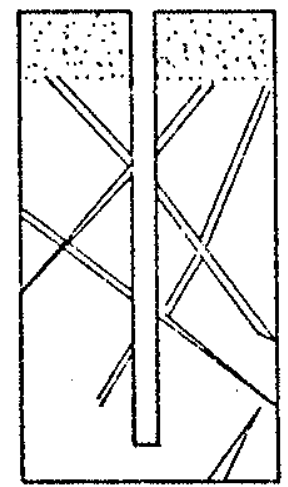

(9)
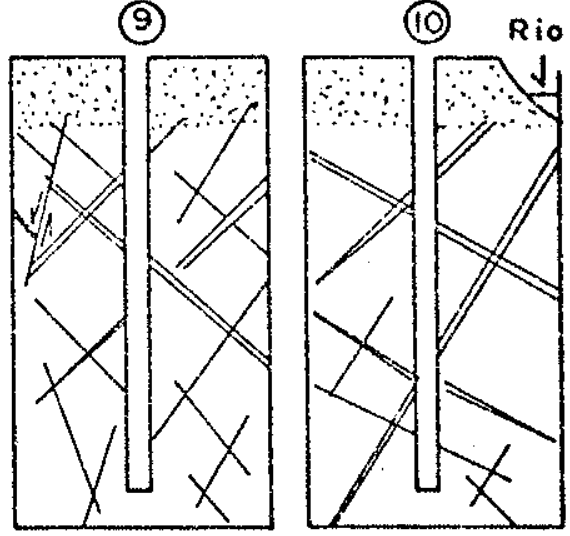

- MANTO de alteraçāo

(1) E (1) - CONDIC̄̄ES EXTREMAS DE
EXPLORAÇĀO

(5)

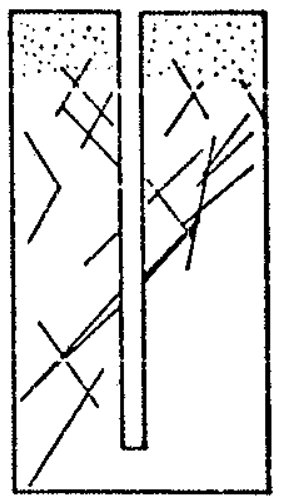

(10) Rio

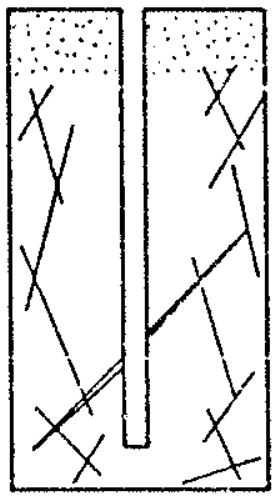

9

- ROCHA SÁ

坟 - FRATURA

Figura 30 - Situacōes encontradas na perfuracão de um poso no contexto cristalino (DUARTE 1985) 
evolução da composição iônica das águas subterrâneas. Além disso, as rochas competentes quando fraturadas tem maior probabilidade de terem fraturas abertas.

As feicões estruturais que se estabeleceram no regime frágil de deformação são as que mais interessam para a pesquisa hidrogeológica, principalmente as fraturas pós-cristalinas, dentre as quais, as abertas são as mais relevantes.

Porēm, em äreas cristalinas sob clima úmido o intemperismo promove a decomposição das rochas, principalmente em zonas de falhas e/ou fraturas, fazendo com que todas elas sejam, em potencial, passiveis de serem boas produtorás de águas subterrāneas.

A congruência de fraturas com a rede de drenagem é uma condição favorável ao armazenamento potencial de águas subterrāneas. Desta forma, é aconselhável que se tenha um mapa de drenagem para que, superposto ao mapa de fraturas, se tenha um dimensionamento dessas zonas; ainda, a integraçăo fratura com arenagem indicară as áreas com maiores espessuras do manto de intemperismo e, consequentemente, com maiores possibilidades de acumulação de àguas.

A configuração do relevo é importante. Verifica-se que inuimeras vezes a procura de ăgua se dá exatamente nos divisores hidrográficos, locais menos propicios à perfuração de poços, e a pesquisa hidrogeológicá deve ficar predominantemente localizađa em áreas de descarga.

\section{Cadastro de Pontos a'Água}

A partir do levantamento das fichas técnicas dos poços tubulares realizado anteriormente, será programada uma fase de campo para se verificar a acuracidade das informacões obtidas e/ou a necessidade de novos dados. 
Como a pesquisa está sendo realizada em domínio cristalino com manto de intemperismo, tornamse necessário o cadastro dos poços escavados e isto só pode ser realizado no campo. As informaçoses sobre estes poços servirão para uma melhor caracterização do manto de alteraça, tanto sob o aspecto de armazenamento quanto da qualidade das águas.

Concomitantemente, se poderá realizar medidas de nivel estătico, $\mathrm{pH}$ e condutividade elétrica que ajudarão a definir as caracteristicas das äguas e definir os poços a serem amostrados para análises físico-químicas e para a realização de testes de bombeamento.

E aconselhável tomar-se anotações sobre os equipamentos de bombeamento, condições de exploração, uso da ãgua, manutenção, operação e profundidade do poço.

Coleta de amostras de äguas subterrâneas para anālises físicoquímicas.

Após a realização das etapas anteriores, com definição do arcabouco geológico e estruturál da ârea de estudo, rede de drenagem, zonas de recarga e descarga e distribuição espacial dos poços é fontes cadastrados, poderá ser iniciada a coleta a'água para análise físico-química $e$, se necessária, bacteriológica.

os pontos amostrados deverão ser criteriosamente selecionados com relação ao meio que será analisado (manto de intemperismo ou fraturado), Iitologia e posicionamento em relação a fraturas e área de descarga/recarga. O cadastro dos poços em campo cria esta possibilidade e a compreensão dos resultados obtidos tornar-se-á mais fácil, pois existirá uma correlação direta com os fatores que influenciam nos resultados. 


\section{Sondagens}

Em quase todos os estudos hidrogeológicos já realizados em terrenos cristalinos com manto de intemperismo é comum se observar a generalização dos parâmetros químicos ou hidrodinâmicos, geralmente adotados como pertencentes ao meio fraturado.

Porém, verifica-se que estes dois meios hidrogeológicos säo distintos, tanto em termos de potencial de armazenamento quanto de qualidade das águas subterrâneas, e que a generalidade não pode existir, pois implicará em sérios erros de interpretação.

Para definição da espessura do manto, pode-se utilizar métodos geofísicos (eletro-resistividade ou eletro-magnético). Porém, se nas fichas técnicas dos poços tubulares constar informações sobre a profundidade do revestimento (que é utilizado somente no manto), tem-se os dados das espessuras reais da zona alterada e se a distribuição espacial dos poços for considerada boa não é necessário a utilização da geofísica.

Com as informações sobre os poços escavados se poderá selecionar os que servirão para testes de bombeamento, a fim de caracterizar hidrodinamicamente a zona alterada.

Para verificar a existência de relação do manto com o meio fraturado, dois procedimentos podem ser utilizados, sendo eles:

10) Caso em que existe poços tubular e escavado muito próximos (distantes até $20 \mathrm{~m}$, dependendo das características do meio geológico): operar o poço tubular e simultaneamente se observar o nível estático dele e do escavado; 
20) não existindo poço escavado, pode-se implantar piezômetro ou poço de observação ao lado do poço. tubular e adotar o procedimento anterior.

Ocorrendo o rebaixamento simultâneo do nivel estático dos poços, fica evidente que o manto de intemperismo funciona como aquífero de transferencia para o meio fraturado.

Caso soja feita a instalação de poso de observação ou piezômetro no manto de inteperismo a fim de monitorar o poço tubular, é conveniente que a perfuração seja aproveitada e se instale um piezômetro multinível, que poderá caracterizar o nível alterado mais promissor em termos de contribuição de água.

Desta forma, a pesquisa neste contexto segue uma metodologia de estudo que possibilitară a caracterização das zonas aquíferas, e cada etapa servirā de suporte básico para a seguinte. 
A área em estudo possui como principais litologias os gnaisses e migmatitos do Complexo Amparo $(55,58)$ e os macicos graniticos de Socorro (23 8) e Atibaia (9 8$)$, secundados pelas aluviões $(7,88)$ e coberturas sedimentares $(3,98)$.

A foliação principal apresenta đireção EW com pequenos mergulhos para $S W$ e SE e foram definidos três conjuntos de dobras, $\mathrm{Fn}+1, \mathrm{Fn}+2$ e $\mathrm{Fn}+3$, onde as primeiras são as mais antigas. A região é intensamente fraturada, onde dois sistemas de fraturas predominam, um com direcão $N 50 \%$ a $550 \mathrm{O}$ e outro com $\mathrm{N} 450$ a $60 \%$, ambos com mergulhos sub-verticais. A principal falha secciona a área com direção N35oE e representa a continuidade da falha de Extrema.

Foram definidas duas zonas aquiferas, distintas entre si: manto de intemperismo e meio fraturado. A espessura da primeira situa-se, predominantemente, entre 20,0 e 40,0 metros (68 8 ), porém atingindo atẻ 60,0 metros.

Apesar dos baixos valores que predominam para a condutividade hidraülica do manto $\left(10^{-3}\right.$ a $\left.10^{-5} \mathrm{~cm} / \mathrm{s}\right)$, suas espessuras fazem com que apresente uma média transmissividade, tornando-o potencialmente capaz de produzir boas vazões.

os nivejs estäticos das duas zonas aquiferas mostram que existe uma estreita correlação entre elas, o que reflete uma interação cntre as mesmas. As medidas de $p H$ e condutividade elétrica e os piezômetros multiniveis comprovan esta relação, deixando claro que existe transferência das águas do manto de intemperismo para o meio fraturado.

As vazões dos poços tubulares são baixas para o contexto explorado, já que 90 o delas situam-se abaixo de $10 \mathrm{~m}^{3} / \mathrm{h}$ e destas, 55 são menores do que $5 \mathrm{~m}^{3} / \mathrm{h}$. A capacidade 
especifica obtida, com minimo de $2 \times 10^{-3}$ e máximo de $0,67\left(\mathrm{~m}^{3} / \mathrm{h}\right) / \mathrm{m}$, méaia de $6 \times 10^{-2}\left(\mathrm{~m}^{3} / \mathrm{h}\right) / \mathrm{m}$, deve ser utilizada com precauça, pois estes valores foram obtidos de pocos tubulares que podem estar captando os dois aquiferos, haja vista que a capacidade especifica média obtida para o manto de intemperismo (resultante de somente três testes de vazão) foi de $0,255\left(\mathrm{~m}^{3} / \mathrm{h}\right) / \mathrm{m}$.

Não observanse nenhum critério de locação, perfuração e completação dos poços tubulares, sendo que a primeira está essencialmente associada a localização da demanda, e exemplos disto são os poços situados em divisores d'ägua. A perfuração está ligada a premissa e ao ingênuo desconhecimento dè que quanto maior profundidade, maiores serão as probabilidades de se obter melhores vazões; a complementação carece de maior conhecimento das normas técnicas e de que o manto de intemperismo é uma zona aquifera, que deve ser explorada em sua máxima plenitude.

Um cálculo estimativo das reservas hidricas subtexrâneas para as zonas aquiferas porosas mostra que existe um potencial para as reservas renováveis de $92 \times 10^{6} \mathrm{in}^{3} / \mathrm{ano}$ e $7,8 \times 10^{6} \mathrm{~m}^{3} /$ ano para 0 manto de intemperismo e aluviões, respectivamente, enquanto que as reservas permanentes são de 109 $\times 10^{6} \mathrm{~m}^{3}$ para o primeiro e de $11,5 \times 10^{6} \mathrm{~m}^{3}$ para o segundo. Isto mostra que existe um volume hidrico considerável para ser explorado, através das construcões de obras de captação com apoio técnico e cientifico.

As águas do manto são essencialmente bicarbonatadas cálcicas e as do fraturado são bicarbonatadas mistas gradando para sódicas e cálcicas.

A hidrólise é o principal processo de intemperismo que atua na região, sendo que as águas dos pocos escavados pertencem ao campo da monossialitização e as dos tubulares situam-se no 
dominio da bissialitização. A caolinita e a montmorilonita cálcica são os dois principais argilo-minerais liberadores dos ions principais para as águas subterrâneas.

os poços escavados são isentos de normas de locacão e completação, existindo uma necessidade premente de oxientação técnica ao que se concerne principalmente aos aspectos de proteção sanitária.

Existem 67 \&os poços tubulares em exploração, senđo que acima de $50 \&$ deles são utilizados para uso doméstico. E necessāria a aplicação das normas legais existentes para que o usuário zele pela obra, preservando o potencial híarico subterxâneo à medida em que diminui a possibilidade de uma poluição antrópica.

A metodologia utilizada mostrou-se amplamente satisfatooria, à meảida em que os resultados eram interpretados e correlacionados com os fatores intervenientes, podendo ser adotada para qualquer estudo hidrogeológico desenvolvido neste contexto. 


\section{7 - REFERENCIAS BIBLIOGRAFICAS}

ARTUR, A. C. - 1980 - Rochas metamórficas dos arredores de Itapira - São Paulo. Dissertação de Mestrado. Instituto da Geociências da Universidade de são Paulo. Circulação restrita. São paulo, 193 pp.

ASSOCIAÇAO BRASILEIRA DE NORMAS TECNICAS (ABNT) - 1977 Elaboração de projetos de poços tubulares profundos para captação de água subterrânea. Projeto NB-588/77, Rio de Janeiro, $7 \mathrm{pp}$.

BERTACHINI, A. C. - 1987 - Estudo das características hidrogeolögicas, dos terrenos cristalinos sob o clima ümido na região de Jundiai, em São Paulo. Dissertação de Mestrado. IG/USP. Circulacão restrita. São Paulo, $105 \mathrm{pp}$.

BISTRICHI, C. A.; CARNEIRO, C. D. R.; DANTAS, A. S. L.; PONÇANO, W. L.; CAMPANHA, G. A. C.; NAGATA, N.; ALMEIDA M. A.; STEIN, D. P.; MELO, M. S.; CREMONINI, O. A. - 1981 - Mapa Geológico do Estado de são Paulo - Escala 1:500.000. PRO-MINERIO/IPT. São paulo. $126 \mathrm{pp}$.

CARVALHO, R. A.; LEPSCH, I. F.; OLIVEIRA, J. B.; VALADARES, J. 1975 - Levantamento pedolögico semidetalhado do municipio de Atibaia, SE. BRAGAîtina. Vol. 34. Tomo tuico. São Paulo. pp. $1-58$.

CAVALCANTE, J. C.; CUNHA, H. C. da S.; CHIEREGATI, L. A.; KAEFER, L. Q.; ROCHA, J. M. da; DAITX, E. C.; COUTINHO, M. G. da N.; YAMAMOTO, K.; DRUMOND, J. B. U.; ROSA, D. B.; RAMALHO, R. 1979 - Projeto Sapucai, Estados de São Paulo, Rio de Janeiro e Minas Gerais; Relatório Final de Geologia. DNPM/CPRM, Superintendência Reg. de São Paulo, Série Geologia, 5a. Secão Geologia Básica, 299 pp. 
CAMPOS NETO, M. C. \& BASEI, M. A. S. - 1983 - Evolucão estrutural brasiliana do nordeste de são paulo: dobramentos superpostos e esboço estratigráfico e tectônico. Atas do 48 Simp. Reg. Geol., SBG. São paulo, pp. $61-78$.

; BASEI, M. A. S.; AJVES, F. R.; FIGUEIREDO,

M. C. H. - 1384 - Geologia da Folha de Bragança Paulista; $1: 50.000$. Relatório PRO-MINERIO. Convênio SICCT/Pró-Minério e IG/USP, São Paulo, Vol. I, $162 \mathrm{pp}$.

CAVAlcante, I. N. - 1978 - Critérios de locação de poços em regiões cristalinas. Seminärios Gerais. Curso de pós-Graduação, IG/USP, Cixculação Restrita, São Paulo, 34 pp.

CAVALCANTE, I. N. \& REBOUÇAS, A. C. - 1989 - Caracterização hiarogeológica de terrenos cristalinos com manto de alteracão. 60 Encontro Nacional de Perfurações de Poços. 20 Simpösio de Hidrogeologia do Nordeste. Natal - RN, $12 \mathrm{pp}$.

CRUz, W. B. - 1985 - A qualidade da ägua em rochas fraturadas. I Simpósio Nacional de Aguas subterrāneas em Rochas Fraturadas. ANAIS. ABAS/MG, Belo Horizonte, pp. $40-54$.

CUSTODIo, E. G. \& LLAMAS, M. S. - 1976 - Hidrologia subterrânea. Ed. Omega, Barcelona, Vol. I e II, $2.359 \mathrm{pp}$.

DEPARTAMENTO DE AGUAS E ENERGIA ELETRICA (DAEE) - SP - 1981 Estudo de águas subterrâneas. Região Administrativa nümero 5 . CAMPINAS - Vol. 1. São Paulo. 607 FE. Mapas.

DRISCOLL, F. G. - 1986 - Groundwater and Wells. Second Edition. Chapter 6 - Groundwater Chemistry. Johnson Division. pp. 86 116. 
DUARTE, W. - 1985 - Avaliação dos critérios de locação de pocos em rochas cristalinas. I simp. Nac. de Agua subterrânea em Rochas Fraturadas. ANAIS. ABAS/MG, Belo Horizonte, pp. 133 143.

DUARTE, U. \& KANEHISA, M. S. - 1986 - Captacões rasas em zonas urbanas. 40 Congresso Bras. de Aguas Subterrāneas. ANAIS. ABAS. Brasilia - DF. pp. 237 - 250 .

EBERT, H. \& BROCHINI, M. F. - 1968 - Estudos estratigráficos e geomorfolögicos no Escudo Cristalino Brasileiro. Rev. Ciência e Cultura, Voi. 20 (3), pp. 621 - 625 .

EETter JR., C.W. - 1980 - Applied Hydrogeology. Bell \& Howell Company, sidney. $488 \mathrm{pp}$.

FONSECA, M. J. G.; StIVA, Z. C. G. da; CAMPOS, D. A.; TOSATTO, P. - 1979 - Carta geolögica do Brasil ao milionésimo - folhas Rio de Janeiro (SF. 23), Vitória (SF. 24) e Iguape (SG. 23) . Texto explicativo, Brasilia, 240 pp.

FREEZE, R. A. \& CHERRY, J. A. - 1979 - Groundwater. PrenticeHall Inc. New Jersey. 604 pp.

GONÇALVES, R. I. F. - 1978 - Critérios fotogeológicos para locā̧ã̃o de poços em rochas cristalinas de Minas Gerais. XXX Cong. Bras. de Geologia. ANAIS. Vol. 6, Recife, pp. 2934 2942.

KAY, L. - 1987 - Hydrogeochemistry applied to development of crystalline bedrock aquifers. Proceeding workshop held in zimbabwe, Harare, Commonwealth Sciences Council, Technical Publication Series, NO 232, London, 8 pp.

KRAUSKOPF, K. B. - 1972 - Introdução à geoquímica. Ed. da Universidade de são Paulo, São Paulo, Vol. I, 294 pp. 
HASUI, Y.; PONCANO, W. L.; BISTRICHI, C. A.; STEIN, D. P.; GALVAO, C. A. C. F.; GIMENEZ, A. F.; ALMEIDA, M. A.; MELO, M. S.; PIRES NETO, A. G. - 1977 - As grandes falhas do leste paulista. Atas do 10 Simp. Geol. Reg., São Paulo, pp. 369 380 .

HAMA, N.; ALGARTE, J. P.; KAEFER, L. Q.; ARTUR, A. C. - 1979 Idades $\mathrm{Rb} / \mathrm{Sr}$ e $\mathrm{K} / \mathrm{Ar}$ na região sul de Minas Gerais e Leste do Estado de são paulo. Atas do 20 Simpósio de Geologia Regional Rio Claro - SP. SBG, Vol. 1, pp. 71 - 86 .

HEM, J. D. - 1985 - Study and Interpretation of the Chemical Caracteristics of natural water. U. S. Geol. Survey, water Supply paper, Ne $1.473,269 \mathrm{pp}$.

LOGAN, J. - 1965 - Interpretaça de Anälises Químicas de Aguas. USAID, Recife, $67 \mathrm{pp}$ (Brochura).

MATTHESS, G. - 1982 - The Properties of Groundwater. John Wiley. Sons, Inc., New York, $405 \mathrm{pp}$.

MELLO, z. - 1975 - Formação e deposição das argilas minerais. Curso de Mestrado, Universidade Federal de Pernambuco, Recife (Seminărio) inédito. $45 \mathrm{pp}$.

MELFI, H: J. - 1986 - Geoquimica de Superficie Curso de posGraduação. IG/USP, São Paulo.

MORALES, N.; OLIVEIRA, N. A. F. de; SIMOES, L. S. A. - 1985 - As estruturas dobradas na região de Atibaia (SP). Atas do 50. Simp. Reg. de Geologia, SBG/SP, São Paulo, Vol. 1. pp. 159 168 . 
OLIVEIRA, M. A. F.; MORALES, N.; FOLFARO, V. J.; CAMPOS, E. G. 1985 - projeto Atibaia - Geologia da Quadricula de Atibaia $1: 50.000$ Relatório Final. Univ. Est. Paulista Júlio de Mesquita Filho. Inst. Geoc. e Ciênc. Exatas, Campus de Rio Claro. Contrato SICCT (PRO-MINERIO). UNESP, $117 \mathrm{pp}$.

PENALVA, F. - 1971 - Sedimentos neo-cenozóicos nos vales dos rios Jundiai, Atibaia e Jaguari (Estado de são Paulo). Boletim Anual Geografia, SP, Vol. 46. pp. 107 - 138 .

PARISOT, E. H. - 1383 - As Aguas Subterxâneas no Centro-Oeste do Municipio de são paulo - Caracteristicas hidrogeolögicas e químicas. Dissertação de Mestrado. IG/USP. Circulação restrita. IG/USP. São Paulo. $94 \mathrm{pp}$.

PIUCI, J. - 1978 - Hidrogeologia da área piloto ponta de pedras Ilha do Marajó. Dissertação de Mestrado. Nücleo de Ciências Geofísicas e Geolögicas - Univ. Federal do pará. Circulação restrita. $143 \mathrm{pp}$.

QUIST, I. G. - 1987 - Groundwater utilisation in the precambrian crystalline basement rocks of Ghana. Proceedings workshop held in zimbabwe, Harare, Commomwealth Sciences Council, Technical. Publication Sexies No 232. $14 \mathrm{p}$.

REBOUCAS, A. C. \& CAVALCANTE, I. N. - 1988 - Hyarogeology of Crystalline Rocks in Brazil. Groundwater Exploration and Development, in Cristalline Basement Aquifers. Harare, Zimbabwe, Africa. Vol. I series number CSC (89) WMR-13, Technical paper 273. pp. $103-126$.

REBOUÇAS, A. C. - 1988 - Groundwater in Brazil. EPISOdES. Vo1. 11, Ne 3, pp. $209-214$.

SCHOELLER, H. - 1962 - Les Eaux Souterraines. Masson \& Cie., Editeurs, Paris. 642 pp. 
SETZER, J. - 1964 - Fraturas observadas em fotografias aéreas e sua significacão hiarogeológica. Bol. Soc. Bras. Geologia, vol. 13, Ne $1-2$, pp. $55-60$.

- 1966 - Agua subterrânea no cristalino paulista. Rev. Bras. de Geografia, Ne 3, pp. 3 - 19.

SCHOBBENHAUS FILHO, C; Coord. - 1981 - Carta Geológica do Brasil, $1: 2.500 .000$, DNPM, Brasilia.

SIQUerRA, L. - 1967 - Contribuição da Geologia à Pesquisa de Água Subterrânea no Cristalino. Agua Subterxânea, Vol. 9. Recife. pp. $1-29$.

SILVA, R. B. G. da - 1983 - Estudo hidroquímico e isotópico das ăguas subterrāneas do aquífero Botucatu no Estado de são paulo. Tese de Doutoramento. Instituto de Geocjências da Universidade de são paulo, Inédita. 133 pp.

SZIKSZAY, M. - 1986 - Geoquímica das Aguas. Curso de pósGraduação. Instituto de Geociências da universidade de são Paulo. São paulo.

TODD, D. K. - 1959 - Groundwater hydrology. John Wiley and Sons, Inc. New York, $336 \mathrm{pp}$.

WERNICK, E; OLIVEIRA, M. A. F. de; KAWASHITA, K.; CORDANI U. G.; DELHAL, J. - 1976 - Estudo geocronológico pelo mëtodo Rb/Sr em rochas do Bloco Jundiai e regiões adjacentes. Revista Bras. de Geociências/SBG, Vol. 6. pp. 125 - 135 .

WERNICK, E. - 1978 - Contribuição à estratigrafia do PréCambriano do leste do Estado do são paulo e áreas vizinhas. Rev. Bras. Geoc., vol 8, pp. $206-216$. 
WERNICK, E. \& PENALVA, F. - 1978a - Contribuicão ao conhecimento das rochas granitöides do sul do Brasil. Rev. Bras. Geoc., Vol. 8. pp. $113-133$.

WERNICK, E. e PENALVA, F. - 1978b - O Grupo Pinhal na Região Nordeste do Estado de São Paulo e Áreas vizinhas do Estado de Minas Gerais. Cong. Bras. de Geol., Bol. Esp. pp. 315 - 316 .

WRIGHT, E. P. \& HERBERT, R. - 1985 - Collector wells in basement aquifers. Waterlines, Vol. 4 ne 2. pp. 8 - 11 . 
A N E X O S 
ANEXO 01

CARACTERTSTICAS DOS POCOS TUBULARES DA REGTAO DE ATYBAIA (SP) . 


\begin{tabular}{|c|c|c|c|c|c|c|c|c|c|c|c|c|c|c|}
\hline $\begin{array}{l}\text { KO DE } \\
\text { ORDEY }\end{array}$ & LOCALIZACËO & $\begin{array}{c}\text { ALTITUDE } \\
\text { APROXIMADA } \\
(n) *\end{array}$ & $\begin{array}{c}\text { FIRMA } \\
\text { PERFURADORA }\end{array}$ & $\begin{array}{c}\text { DATA DE } \\
\text { PERFURAÇAO }\end{array}$ & $\begin{array}{l}\text { PROFUN } \\
\text { DIDADE } \\
\text { (m) }\end{array}$ & $\begin{array}{l}\text { N.E. } \\
\text { (m) }\end{array}$ & $\begin{array}{l}\text { N.D. } \\
(m)\end{array}$ & $\left|\begin{array}{c}Q \\
\left(m^{3} / H\right)\end{array}\right|$ & $\begin{array}{c}\text { CAP. } \\
\text { ESP. } \\
\left(\mathrm{m}^{3} / \mathrm{h}\right) / \\
\mathrm{m}\end{array}$ & $\begin{array}{l}\text { LITO- } \\
\text { LOGIA }\end{array}$ & $\begin{array}{c}\text { ESP.DO } \\
\text { MANTO } \\
\text { DE ALT } \\
(\mathrm{m})\end{array}$ & $\begin{array}{c}\text { FRATURAS } \\
\dot{a} \\
(m)\end{array}$ & $\mathrm{pH}$ & $\begin{array}{l}\text { COND. } \\
\text { EL. } \\
\text { uS/cm } \\
a \quad 250 C \\
\end{array}$ \\
\hline 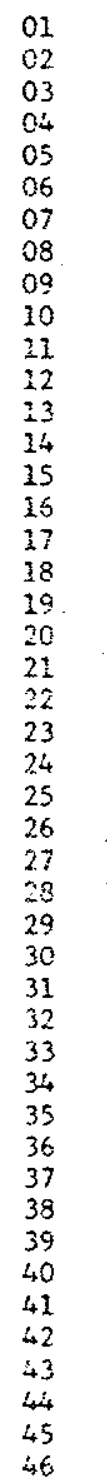 & 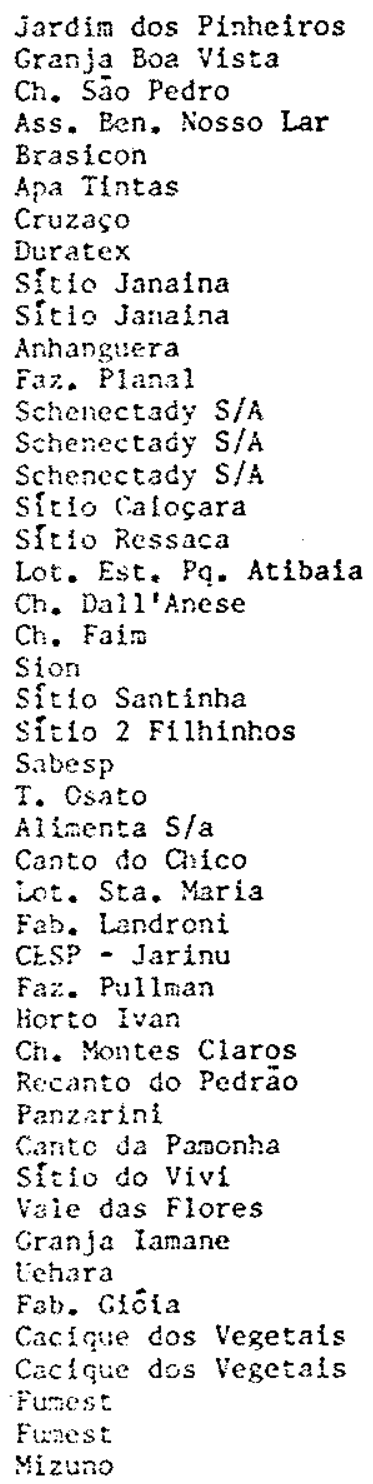 & $\begin{array}{l}770 \\
810 \\
780 \\
770 \\
730 \\
780 \\
800 \\
780 \\
820 \\
820 \\
800 \\
750 \\
740 \\
740 \\
740 \\
880 \\
745 \\
800 \\
770 \\
800 \\
790 \\
810 \\
800 \\
770 \\
750 \\
800 \\
740 \\
860 \\
770 \\
780 \\
790 \\
770 \\
730 \\
820 \\
- \\
800 \\
780 \\
820 \\
820 \\
740 \\
760 \\
760 \\
760 \\
780 \\
780 \\
750\end{array}$ & $\begin{array}{l}\text { Jundsondas } \\
\text { Air Lift } \\
\text { Jundsondas } \\
\text { Falcāo \& Olsen } \\
\text { Rodágua } \\
\text { Jundsondas } \\
\text { Jundsondas } \\
\text { Jundsondas } \\
\text { Corner } \\
\text { Geopesquisadora } \\
\text { T. Janer } \\
\text { T. Janer } \\
\text { T. Janer } \\
\text { Supersondas } \\
\text { Jundsondas } \\
\text { Bravo } \\
\text { Jundsondas } \\
\text { Jundsondas } \\
\text { Jundsondas } \\
\text { Jundsondas } \\
\text { Jundsondas } \\
\text { Air Lift } \\
\text { Air Lift } \\
\text { Saiägua } \\
\text { Supersondas } \\
\text { Falcäo \& Olsen } \\
\quad- \\
\text { Geopesquisadora } \\
\text { Tringil } \\
\text { Politi } \\
\text { Tringil } \\
\text { Politi } \\
\text { Corner } \\
\text { Air Lift } \\
\text { Air Lift } \\
\text { Air Lift } \\
\text { Air Lift } \\
\text { Politi } \\
\quad- \\
\text { - }\end{array}$ & 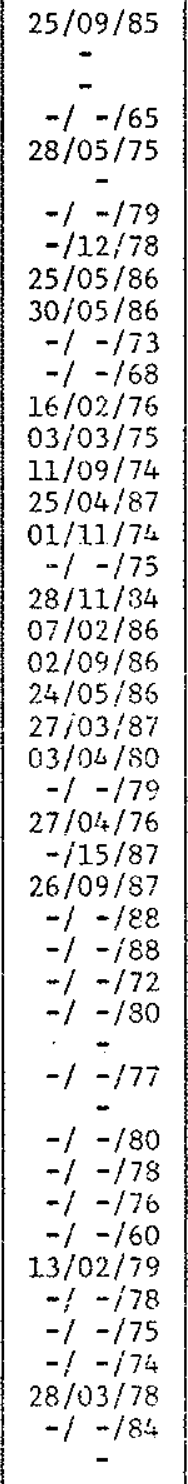 & $\begin{array}{c}155 \\
- \\
- \\
80 \\
150 \\
- \\
193 \\
123 \\
- \\
150 \\
220 \\
180 \\
215 \\
215 \\
150 \\
144 \\
150 \\
120 \\
132 \\
122 \\
120 \\
150 \\
142 \\
160 \\
203 \\
220 \\
50 \\
180 \\
- \\
180 \\
110 \\
343 \\
155 \\
93 \\
85 \\
80 \\
78 \\
133 \\
60 \\
150 \\
36 \\
202 \\
126 \\
150 \\
151 \\
190\end{array}$ & $\begin{array}{r}15,0 \\
- \\
- \\
15,0 \\
6,5 \\
15,0 \\
25,0 \\
0 \\
8,0 \\
10,0 \\
50,0 \\
4,6 \\
6,7 \\
9,0 \\
6,0 \\
39,0 \\
- \\
- \\
0,5 \\
17,0 \\
23,0 \\
7,0 \\
29,0 \\
2,5 \\
1,2 \\
12,0 \\
2,0 \\
39,0 \\
2 \\
- \\
- \\
- \\
12,9 \\
17,5 \\
- \\
9,5 \\
25,0 \\
5,0 \\
2,6 \\
3,7 \\
3,3 \\
1,5 \\
2,0 \\
1,0 \\
6,0 \\
4,0\end{array}$ & $\begin{array}{r}74,0 \\
- \\
35,0 \\
63,0 \\
- \\
90,0 \\
77,0 \\
115,0 \\
106,0 \\
140,0 \\
- \\
59,4 \\
89,8 \\
42,0 \\
123,0 \\
- \\
- \\
63,0 \\
110,0 \\
91,0 \\
132,0 \\
85,0 \\
106,8 \\
98,5 \\
120,0 \\
22,5 \\
150,0 \\
- \\
- \\
49,0 \\
2 \\
- \\
80,0 \\
- \\
26,5 \\
52,0 \\
85,0 \\
-0 \\
119,0 \\
19,0 \\
139,0 \\
89,0 \\
36,0 \\
70,0 \\
112,0\end{array}$ & $\begin{array}{r}8,9 \\
- \\
- \\
3,3 \\
15,0 \\
- \\
8,0 \\
4,6 \\
0,8 \\
0,4 \\
3,7 \\
- \\
13,9 \\
4,5 \\
5,1 \\
0,4 \\
26,0 \\
- \\
18,0 \\
0,7 \\
3,6 \\
1,6 \\
8,0 \\
16,0 \\
2,9 \\
1,3 \\
6,3 \\
0,3 \\
3,3 \\
3,8 \\
70,0 \\
6,5 \\
10,0 \\
1,3 \\
1,5 \\
6,0 \\
0,5 \\
2,4 \\
3,0 \\
8,8 \\
6,5 \\
7,2 \\
3,2 \\
10,5 \\
8,0 \\
5,0 \\
5\end{array}$ & $\begin{array}{c}0,150 \\
- \\
- \\
0,165 \\
0,265 \\
- \\
0,123 \\
0,059 \\
0,007 \\
0,004 \\
0,041 \\
- \\
0,263 \\
0,055 \\
0,141 \\
0,004 \\
- \\
- \\
0,285 \\
0,007 \\
0,052 \\
0,012 \\
0,121 \\
0,153 \\
0,029 \\
0,012 \\
0,307 \\
0,002 \\
- \\
- \\
- \\
- \\
0,020 \\
- \\
0,352 \\
0,028 \\
0,030 \\
- \\
0,076 \\
0,401 \\
0,052 \\
0,036 \\
0,300 \\
0,125 \\
0,046\end{array}$ & $\begin{array}{c}\text { TQC } \\
- \\
- \\
\text { agn } \\
\text { agn } \\
- \\
\text { agn } \\
\text { agn } \\
\text { agn } \\
\text { agn } \\
\text { agn } \\
- \\
\text { agn } \\
\text { agn } \\
\text { agn } \\
\text { sgr } \\
\text { agn } \\
- \\
\text { agn } \\
\text { sgr } \\
\text { agr } \\
\text { agn } \\
\text { agn } \\
\text { agn } \\
\text { agn } \\
\text { agn } \\
\text { agn } \\
\text { sgr } \\
- \\
\\
\text { sgr } \\
\end{array}$ & 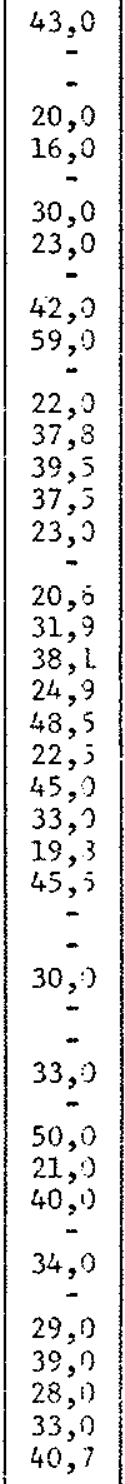 & 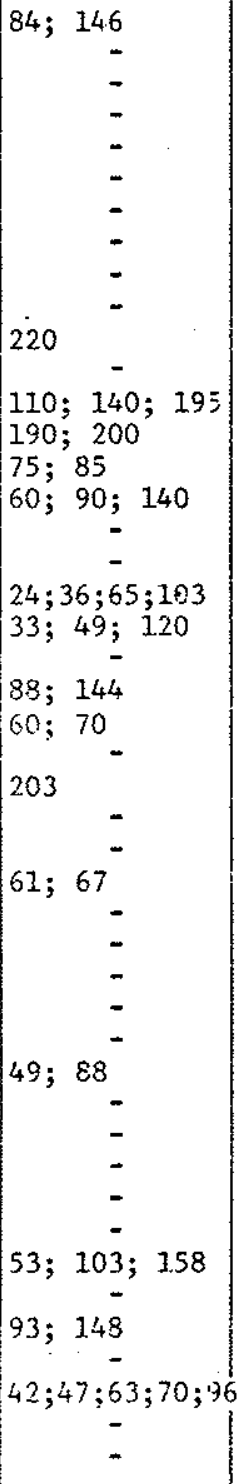 & 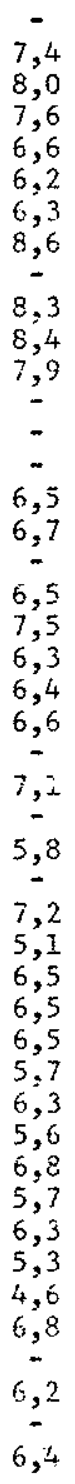 & $\begin{array}{r}111 \\
110 \\
103 \\
57 \\
202 \\
60 \\
121 \\
151 \\
- \\
176 \\
133 \\
173 \\
201 \\
200 \\
- \\
129 \\
153 \\
- \\
98 \\
157 \\
76 \\
99 \\
132 \\
- \\
134 \\
- \\
130 \\
- \\
112 \\
15 \\
162 \\
186 \\
09 \\
91 \\
153 \\
88 \\
155 \\
171 \\
160 \\
162 \\
30 \\
143 \\
- \\
100 \\
110 \\
125\end{array}$ \\
\hline
\end{tabular}




\begin{tabular}{|c|c|c|c|c|c|c|c|c|c|c|c|c|c|c|}
\hline $\begin{array}{l}\text { NO DE } \\
\text { ORDEMI }\end{array}$ & LOCALIZAÇAOOO & $\begin{array}{c}\text { ALTITUDE } \\
\text { APROXIMADA } \\
(\mathrm{m})^{*}\end{array}$ & $\begin{array}{c}\text { FIRMA } \\
\text { PERFURADORA }\end{array}$ & $\begin{array}{c}\text { DATA DE } \\
\text { PERFURACח̃OO }\end{array}$ & $\begin{array}{l}\text { PROFUN } \\
\text { DIDAD } \\
(\mathrm{m})\end{array}$ & $\begin{array}{l}\mathrm{N} . \mathrm{E} . \\
(\mathrm{m})\end{array}$ & $\begin{array}{l}\text { N.D. } \\
\text { (m) }\end{array}$ & $\begin{array}{c}Q \\
\left(m^{3} / h\right)\end{array}$ & $\begin{array}{c}\text { CAP. } \\
\text { ESP } \\
\left(\mathrm{m}^{3} / \mathrm{h}\right) / \\
\mathrm{m}\end{array}$ & $\begin{array}{l}\text { LITO- } \\
\text { LOCIA }\end{array}$ & $\begin{array}{c}\text { ESP.DO } \\
\text { MNTO } \\
\text { DE ALT } \\
(m)\end{array}$ & $\begin{array}{c}\text { FRATURAS } \\
\bar{a} \\
\text { (a) }\end{array}$ & $\mathrm{pH}$ & $\begin{array}{l}\text { COND. } \\
\text { EL. } \\
125 / \mathrm{cm} \\
\bar{\sigma} 250 \mathrm{C} \\
\end{array}$ \\
\hline $\begin{array}{l}47 \\
48 \\
49 \\
50 \\
51 \\
52 \\
53 \\
54 \\
55 \\
56 \\
57 \\
58 \\
59 \\
60 \\
61 \\
62 \\
53 \\
54 \\
65 \\
66 \\
67 \\
65 \\
69 \\
70 \\
71 \\
72 \\
73 \\
74 \\
75 \\
76 \\
77 \\
78 \\
79\end{array}$ & 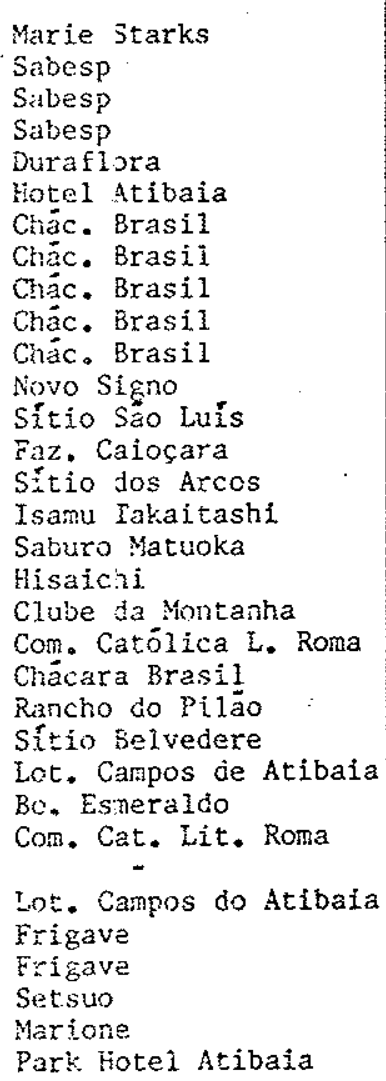 & $\begin{array}{l}770 \\
800 \\
800 \\
780 \\
830 \\
760 \\
790 \\
770 \\
750 \\
795 \\
795 \\
780 \\
810 \\
820 \\
940 \\
780 \\
800 \\
795 \\
- \\
- \\
- \\
- \\
- \\
- \\
- \\
- \\
- \\
- \\
- \\
- \\
-\end{array}$ & $\begin{array}{l}\text { Ergo } \\
\text { Politi } \\
\text { Hidrogesp } \\
\text { Politi } \\
\text { Tringil } \\
\text { Air Jift } \\
\text { T. Janer } \\
\text { Ergo } \\
\text { Ergo } \\
\text { Ergo } \\
\text { Ergo } \\
\text { Politi } \\
\text { Conner } \\
\text { Pe: furat } \\
\text { Alfa Tokio } \\
\text { Air Lift } \\
\text { T. Janer } \\
\text { Geopesquisadora } \\
\text { Politi } \\
\text { Aguater } \\
\quad- \\
\text { Tringil } \\
\text { Ergo } \\
\text { Geopesquisadora } \\
\text { Ergo } \\
\quad- \\
\quad- \\
- \\
\text { Yanagata } \\
\quad- \\
-\end{array}$ & 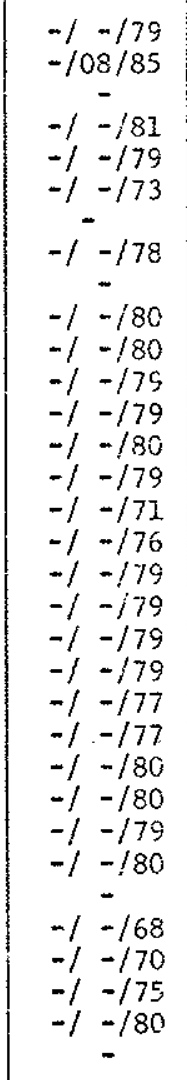 & $\begin{array}{r}80 \\
200 \\
180 \\
165 \\
240 \\
180 \\
102 \\
142 \\
80 \\
70 \\
63 \\
150 \\
140 \\
140 \\
150 \\
80 \\
130 \\
165 \\
123 \\
249 \\
101 \\
70 \\
113 \\
200 \\
81 . \\
56 \\
- \\
142 \\
60 \\
70 \\
130 \\
108 \\
120\end{array}$ & $\begin{array}{r}19,0 \\
6,9 \\
0,6 \\
4,4 \\
30,0 \\
6,0 \\
17,0 \\
22,0 \\
25,0 \\
44,0 \\
36,0 \\
12,0 \\
19,0 \\
1,7 \\
28,0 \\
- \\
- \\
3,5 \\
5,3 \\
12,0 \\
= \\
= \\
= \\
- \\
- \\
- \\
= \\
- \\
= \\
= \\
-\end{array}$ & $\begin{array}{r}- \\
78,6 \\
8,8 \\
25,3 \\
200,0 \\
115,0 \\
65,0 \\
112,5 \\
- \\
- \\
- \\
80,0 \\
116,0 \\
- \\
96,0 \\
- \\
- \\
110,0 \\
- \\
- \\
= \\
- \\
- \\
= \\
- \\
- \\
- \\
= \\
- \\
61,0\end{array}$ & $\begin{array}{l}8,0 \\
6,0 \\
5,5 \\
5,1 \\
0,4 \\
4,2 \\
7,2 \\
2,8 \\
1,0 \\
2,0 \\
2,0 \\
6,5 \\
2,5 \\
2,7 \\
0,6 \\
2,0 \\
- \\
4,4 \\
1,5 \\
1,2 \\
9,0 \\
5,4 \\
5,0 \\
1,8 \\
8,0 \\
2,4 \\
- \\
- \\
- \\
- \\
- \\
-\end{array}$ & $\begin{array}{c}- \\
0,083 \\
0,670 \\
0,244 \\
0,002 \\
0,038 \\
0,150 \\
0,030 \\
- \\
= \\
- \\
0,095 \\
0,925 \\
- \\
0,009 \\
- \\
0,041 \\
- \\
- \\
- \\
- \\
- \\
- \\
- \\
- \\
- \\
- \\
- \\
-\end{array}$ & $\begin{array}{c}- \\
\text { agn } \\
\text { sgr } \\
\text { agn } \\
\text { agn } \\
\text { am } \\
\text { agn } \\
\text { agn } \\
\text { sgr } \\
\text { sgr/agn } \\
\text { sgr/agn } \\
\text { sgr } \\
\text { agn } \\
\text { sgr } \\
\text { sgriagn } \\
\text { agn } \\
\text { agn } \\
a g n \\
- \\
- \\
- \\
- \\
- \\
- \\
- \\
- \\
- \\
-\end{array}$ & $\begin{array}{r}- \\
35,5 \\
18,0 \\
22,0 \\
26,0 \\
34,7 \\
41,0 \\
37,8 \\
25,0 \\
35,0 \\
37,0 \\
55,0 \\
52,0 \\
24,0 \\
30,0 \\
40,0 \\
15,0 \\
27,0 \\
= \\
= \\
= \\
= \\
= \\
= \\
= \\
= \\
= \\
= \\
=\end{array}$ & 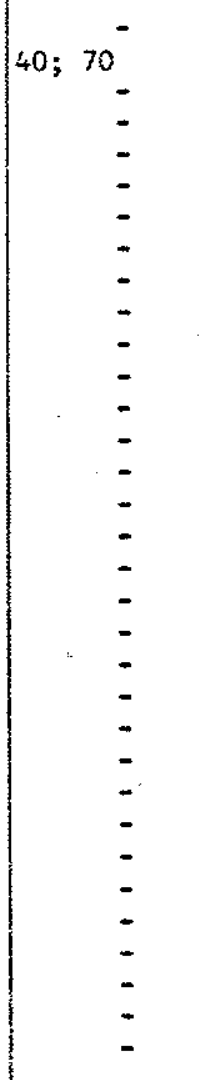 & $\begin{array}{c}5,0 \\
= \\
= \\
= \\
= \\
= \\
= \\
= \\
= \\
= \\
= \\
= \\
= \\
= \\
= \\
= \\
= \\
= \\
=\end{array}$ & 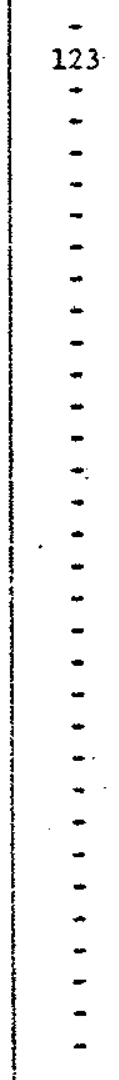 \\
\hline
\end{tabular}

N.E. = Nivel estätico

N.E. = Nivel estatico

N.D. Nivei

Q. Esp. Esp. = Capacidade específica.

$* \quad=$ Altitude aproximada retirade da folha planialtimétrica

SF. 23.C - III-2/MI - ATIBAIA

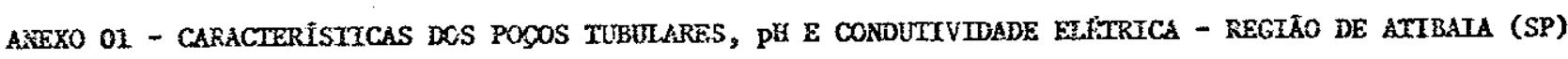


ANEXO 02

CARACTERISTICAS DOS FOCOS ES CAVADOS DA REGTAO DE ATTBATA (SP) 


\begin{tabular}{|c|c|c|c|c|c|}
\hline $\begin{array}{l}\text { No. DE } \\
\text { ORDEM }\end{array}$ & $\underset{(\mathrm{m})}{\mathrm{PROF}}$ & $\underset{(m)}{N . E .}$ & $\mathrm{pH}$ & $\begin{aligned} \text { COND. EL. } \\
\mu \mathrm{s} / \mathrm{cm} \text { a } 250 \mathrm{C}\end{aligned}$ & DATA DO CADASTRO \\
\hline 001 & 10,0 & - & 5,4 & 26 & $05 / 88$ \\
\hline 002 & 7,0 & - & 5,8 & 47 & $05 / 88$ \\
\hline 003 & 10,0 & - & 4,4 & 59 & $05 / 38$ \\
\hline 004 & 12,0 & 9,0 & 5,8 & 30 & $05 / 88$ \\
\hline 005 & 9,0 & - & 6,2 & 79 & $05 / 88$ \\
\hline 006 & 7,0 & 5,0 & 5,9 & 76 & $05 / 88$ \\
\hline 007 & 6,5 & 5,0 & 5,1 & - & $05 / 88$ \\
\hline 008 & 7,5 & 6,0 & 5,7 & - & $05 / 88$ \\
\hline 009 & 5,0 & 3,5 & 4,5 & 64 & $05 / 88$ \\
\hline 010 & 18,0 & - & 6,0 & 27 & $05 / 88$ \\
\hline 011 & 10,0 & 2,0 & 4,9 & 58 & $05 / 88$ \\
\hline 012 & 2,0 & 0,7 & 4,9 & 53 & $05 / 88$ \\
\hline 013 & 5,0 & 3,0 & 5,7 & 35 & $05 / 88$ \\
\hline 014 & 8,0 & 4,0 & 4,8 & 25 & $05 / 88$ \\
\hline 015 & - & - & 5,7 & 38 & $05 / 88$ \\
\hline 016 & 5,0 & 1,0 & 5,7 & 33 & $05 / 88$ \\
\hline 017 & 24,0 & 20,0 & - & - & $05 / 88$ \\
\hline 018 & 8,0 & 6,0 & 4,6 & 26 & $05 / 88$ \\
\hline 019 & - & 1,7 & 5,0 & 32 & $05 / 88$ \\
\hline 020 & 20,0 & 18,0 & 5,0 & 60 & $05 / 88$ \\
\hline 021 & 3,0 & 1,9 & 5,6 & 95 & $05 / 88$ \\
\hline 022 & 2,5 & 2,0 & 6,2 & 190 & $05 / 88$ \\
\hline 023 & 17,0 & 7,5 & 5,9 & 149 & $05 / 88$ \\
\hline 024 & 10,0 & 7,0 & 4,7 & 21 & $05 / 88$ \\
\hline 025 & 9,0 & 7,0 & 6,1 & 84 & $05 / 88$ \\
\hline 026 & 16,0 & 12,0 & 5,8 & 70 & $05 / 88$ \\
\hline 027 & 17,0 & 13,0 & 5,8 & 62 & $05 / 88$ \\
\hline 028 & 20,0 & 18,0 & 6,4 & 72 & $05 / 88$ \\
\hline 029 & 3,5 & 2,0 & 5,7 & 64 & $05 / 88$ \\
\hline 030 & 3,0 & 1,5 & 5,5 & 47 & $05 / 88$ \\
\hline 031 & 7,0 & 5,0 & 5,1 & 43 & $05 / 88$ \\
\hline 032 & 10,0 & 7,0 & 5,5 & 49 & $05 / 88$ \\
\hline 033 & 6,0 & 2,3 & 4,7 & 53 & $05 / 88$ \\
\hline 034 & 14,0 & 5,3 & 5,2 & 209 & $05 / 88$ \\
\hline 035 & 6,0 & 2,0 & 5,8 & 198 & $05 / 88$ \\
\hline 036 & 6,0 & 2,8 & 4,8 & 64 & $05 / 88$ \\
\hline 037 & 25,0 & 18,3 & 7,6 & 116 & $05 / 88$ \\
\hline 038 & 4,0 & 1,8 & 5,2 & 39 & $05 / 88$ \\
\hline 039 & 7,0 & 2,3 & 5,1 & 34 & $05 / 88$ \\
\hline 040 & 3,0 & 0,2 & 5,0 & 44 & $05 / 88$ \\
\hline 041 & 7,0 & 2,0 & 4,7 & 14. & $05 / 88$ \\
\hline 042 & 5,0 & 2,9 & 4,9 & 25 & $05 / 88$ \\
\hline 043 & 5,0 & 1,8 & 5,7 & 59 & $05 / 88$ \\
\hline 044 & 7,0 & 4,8 & 4,9 & 105 & $05 / 88$ \\
\hline 045 & 14,0 & 11,6 & 6,0 & 22 & $05 / 88$ \\
\hline 046 & 5,0 & 3,0 & 5,2 & 26 & $0.5 / 88$ \\
\hline 047 & 4,0 & 2,1 & 4,8 & 16 & $05 / 88$ \\
\hline 048 & 31,0 & 28,0 & 6,8 & 69 & $05 / 88$ \\
\hline 049 & 12,0 & 7,0 & 4,6 & 39 & $05 / 88$ \\
\hline
\end{tabular}




\begin{tabular}{|c|c|c|c|c|c|}
\hline $\begin{array}{l}\text { No. DE } \\
\text { ORDEM }\end{array}$ & $\begin{array}{l}\text { PROF. } \\
(\mathrm{m})\end{array}$ & $\underset{(m)}{N \cdot E .}$ & $\mathrm{pH}$ & $\begin{array}{rl}\text { COND: EL. } & \text { EL } \\
\mu \mathrm{s} / \mathrm{cm} & 25 \mathrm{OC}\end{array}$ & DATA DO CADASTRO \\
\hline $\begin{array}{l}050 \\
051 \\
052 \\
053 \\
054 \\
055 \\
056 \\
057 \\
058 \\
059 \\
060 \\
061 \\
062 \\
063 \\
064 \\
065 \\
066 \\
067 \\
068 \\
069 \\
070 \\
071 \\
072 \\
073 \\
074 \\
075 \\
076 \\
077 \\
078 \\
079 \\
080 \\
081 \\
082 \\
083 \\
084 \\
085 \\
086 \\
087 \\
088 \\
089 \\
090 \\
091 \\
092 \\
093 \\
094 \\
095 \\
096\end{array}$ & $\begin{array}{r}6,0 \\
5,0 \\
10,0 \\
7,5 \\
7,0 \\
10,0 \\
6,0 \\
12,0 \\
10,0 \\
15,0 \\
7,0 \\
8,0 \\
12,0 \\
11,0 \\
10,0 \\
7,0 \\
12,0 \\
14,0 \\
22,0 \\
4,0 \\
10,0 \\
8,5 \\
32,0 \\
6,0 \\
9,0 \\
10,0 \\
6,0 \\
2,5 \\
8,0 \\
10,0 \\
20,0 \\
20,0 \\
12,0 \\
7,0 \\
1,5 \\
12,0 \\
8,0 \\
18,0 \\
28,0 \\
16,5 \\
20,5 \\
14,0 \\
5,0 \\
20,0 \\
8,0 \\
10,0 \\
10,0\end{array}$ & $\begin{array}{r}2,5 \\
3,3 \\
7,3 \\
6,0 \\
5,0 \\
7,8 \\
2,0 \\
9,2 \\
6,5 \\
6,2 \\
4,0 \\
5,4 \\
8,0 \\
5,3 \\
5,6 \\
5,8 \\
9,0 \\
12,6 \\
15,7 \\
2,5 \\
6,5 \\
3,5 \\
22,0 \\
4,5 \\
6,9 \\
7,6 \\
3,0 \\
1,7 \\
3,8 \\
8,0 \\
17,4 \\
9,7 \\
8,0 \\
2,8 \\
0,4 \\
7,0 \\
3,0 \\
12,3 \\
17,4 \\
6,0 \\
11,0 \\
10,5 \\
1,7 \\
13,0 \\
5,8 \\
1,7 \\
6,7\end{array}$ & $\begin{array}{l}6,0 \\
6,0 \\
6,3 \\
5,8 \\
6,1 \\
5,3 \\
4,8 \\
5,6 \\
5,1 \\
4,5 \\
4,3 \\
4,5 \\
5,8 \\
5,4 \\
5,9 \\
6,9 \\
5,5 \\
5,8 \\
5,7 \\
4,8 \\
6,4 \\
5,8 \\
6,9 \\
4,8 \\
5,7 \\
4,9 \\
4,5 \\
5,2 \\
4,7 \\
6,4 \\
6,0 \\
7,2 \\
5,9 \\
5,8 \\
4,8 \\
4,3 \\
6,2 \\
5,2 \\
7,7 \\
6,5 \\
5,9 \\
5,9 \\
5,5 \\
6,1 \\
5,6 \\
5,7 \\
5,7\end{array}$ & 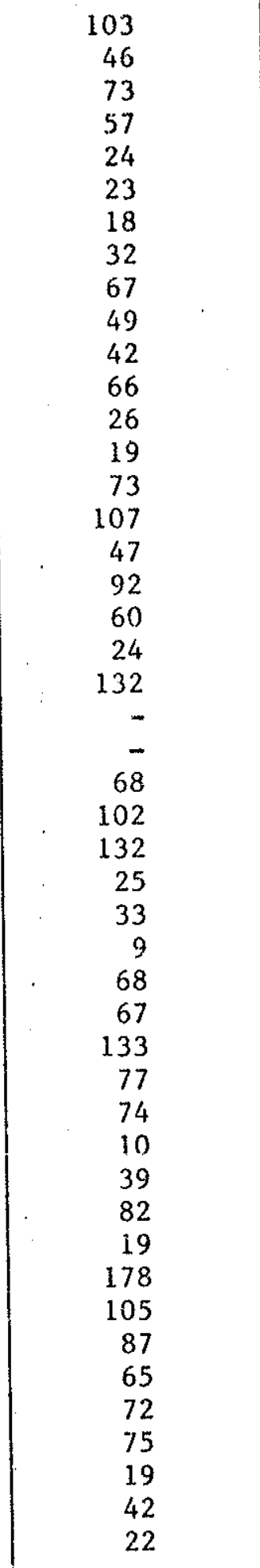 & $\begin{array}{l}05 / 88 \\
06 / 88 \\
06 / 88 \\
06 / 88 \\
06 / 88 \\
06 / 88 \\
06 / 88 \\
06 / 88 \\
06 / 88 \\
06 / 88 \\
06 / 88 \\
06 / 88 \\
06 / 88 \\
06 / 88 \\
06 / 88 \\
06 / 88 \\
06 / 88 \\
06 / 88 \\
06 / 88 \\
06 / 88 \\
06 / 88 \\
06 / 88 \\
06 / 88 \\
06 / 88 \\
06 / 88 \\
06 / 88 \\
06 / 88 \\
06 / 88 \\
06 / 88 \\
06 / 88 \\
06 / 88 \\
06 / 88 \\
06 / 88 \\
06 / 88 \\
06 / 88 \\
06 / 88 \\
06 / 88 \\
06 / 88 \\
06 / 88 \\
06 / 88 \\
06 / 88 \\
06 / 88 \\
06 / 88 \\
06 / 88 \\
06 / 88 \\
06 / 88 \\
06 / 88\end{array}$ \\
\hline
\end{tabular}




\begin{tabular}{|c|c|c|c|c|c|}
\hline $\begin{array}{l}\text { No. DE } \\
\text { ORDEM }\end{array}$ & $\begin{array}{l}\text { PROF. } \\
\text { (m) }\end{array}$ & $\begin{array}{l}N . E . \\
(m)\end{array}$ & pH & $\begin{aligned} \text { COND } & \text { EL. } \\
\mu \mathrm{s} / \mathrm{cm} \text { à } & 25 \Omega \mathrm{C}\end{aligned}$ & DATA DO CADASTRO \\
\hline $\begin{array}{l}097 \\
098 \\
099 \\
100 \\
101 \\
102 \\
103 \\
104 \\
105 \\
106 \\
107 \\
108 \\
109 \\
110 \\
111 \\
112 \\
113 \\
114 \\
115 \\
116 \\
117 \\
118 \\
119 \\
120 \\
121 \\
122 \\
123 \\
124 \\
125 \\
126 \\
127 \\
128 \\
129 \\
130 \\
131 \\
132 \\
133 \\
134 \\
135 \\
136 \\
137 \\
138 \\
139 \\
140 \\
141 \\
142 \\
143 \\
144\end{array}$ & $\begin{array}{r}6,0 \\
10,0 \\
7,0 \\
7,0 \\
8,0 \\
8,0 \\
6,0 \\
8,0 \\
10,0 \\
6,0 \\
6,0 \\
6,0 \\
6,0 \\
7,0 \\
6,0 \\
12,0 \\
16,0 \\
6,0 \\
12,0 \\
6,0 \\
18,0 \\
22,0 \\
3,0 \\
6,0 \\
6,0 \\
7,0 \\
5,5 \\
7,0 \\
8,0 \\
6,5 \\
10,0 \\
7,0 \\
6,0 \\
8,0 \\
5,0 \\
7,0 \\
3,5 \\
20,0 \\
11,0 \\
9,0 \\
6,0 \\
13,0 \\
6,0 \\
3,0 \\
15,0 \\
7,0 \\
7,0 \\
2,5\end{array}$ & $\begin{array}{r}3,8 \\
7,2 \\
3,5 \\
5,1 \\
5,0 \\
1,5 \\
2,7 \\
4,6 \\
6,9 \\
2,5 \\
2,0 \\
2,5 \\
2,3 \\
3,4 \\
0,5 \\
8,2 \\
12,0 \\
3,0 \\
6,7 \\
3,5 \\
13,3 \\
18,8 \\
1,3 \\
4,3 \\
3,4 \\
4,4 \\
1,3 \\
6,3 \\
5,0 \\
4,3 \\
7,4 \\
4,6 \\
5,0 \\
4,9 \\
2,5 \\
4,4 \\
1,7 \\
16,7 \\
6,0 \\
6,5 \\
3,2 \\
0,5 \\
1,7 \\
0,4 \\
12,5 \\
4,7 \\
2,5 \\
1,2\end{array}$ & $\begin{array}{l}5,0 \\
5,1 \\
5,1 \\
5,3 \\
7,0 \\
5,7 \\
5,5 \\
6,3 \\
6,2 \\
5,0 \\
4,6 \\
5,3 \\
5,2 \\
5,1 \\
6,2 \\
4,8 \\
5,1 \\
5,8 \\
6,2 \\
5,0 \\
6,7 \\
5,7 \\
4,5 \\
4,9 \\
4,6 \\
4,5 \\
5,9 \\
6,0 \\
5,9 \\
6,2 \\
5,2 \\
5,2 \\
5,3 \\
5,2 \\
6,4 \\
5,3 \\
4,9 \\
5,9 \\
5,7 \\
5,5 \\
5,2 \\
6,1 \\
4,9 \\
5,5 \\
7,2 \\
5,0 \\
5,3 \\
5,1\end{array}$ & $\begin{array}{r}39 \\
49 \\
45 \\
27 \\
166 \\
49 \\
89 \\
59 \\
96 \\
27 \\
18 \\
80 \\
30 \\
82 \\
195 \\
13 \\
9 \\
169 \\
72 \\
2 \\
179 \\
162 \\
30 \\
54 \\
29 \\
40 \\
152 \\
51 \\
93 \\
16 \\
42 \\
22 \\
46 \\
21 \\
130 \\
56 \\
70 \\
73 \\
147 \\
16 \\
82 \\
112 \\
102 \\
158 \\
105 \\
28 \\
41 \\
2\end{array}$ & $\begin{array}{l}06 / 88 \\
06 / 88 \\
06 / 88 \\
06 / 88 \\
06 / 88 \\
06 / 88 \\
06 / 88 \\
06 / 88 \\
06 / 88 \\
06 / 88 \\
06 / 88 \\
06 / 88 \\
06 / 88 \\
06 / 88 \\
06 / 88 \\
06 / 88 \\
06 / 88 \\
06 / 88 \\
06 / 88 \\
06 / 88 \\
05 / 88 \\
05 / 88 \\
07 / 88 \\
07 / 88 \\
07 / 88 \\
07 / 88 \\
07 / 88 \\
07 / 88 \\
07 / 88 \\
07 / 88 \\
07 / 88 \\
07 / 88 \\
07 / 88 \\
07 / 88 \\
07 / 88 \\
07 / 88 \\
07 / 88 \\
07 / 88 \\
07 / 88 \\
07 / 88 \\
07 / 88 \\
07 / 88 \\
07 / 88 \\
07 / 88 \\
07 / 88 \\
07 / 88 \\
07 / 88 \\
07 / 88\end{array}$ \\
\hline
\end{tabular}




\begin{tabular}{|c|c|c|c|c|c|}
\hline $\begin{array}{l}\text { No. DE } \\
\text { ORDEM }\end{array}$ & $\begin{array}{l}\text { PROF. } \\
(m)\end{array}$ & $\underset{(m)}{N . E .}$ & $\mathrm{pH}$ & $\begin{array}{l}\text { COND. EL. } \\
\mu s / \mathrm{cm} \ddot{a} 259 \mathrm{C}\end{array}$ & DATA DO CADASTRO \\
\hline $\begin{array}{l}145 \\
146 \\
147 \\
148 \\
149 \\
150 \\
151 \\
152 \\
153 \\
154 \\
155 \\
156 \\
157\end{array}$ & $\begin{array}{r}4,0 \\
6,0 \\
14,0 \\
5,0 \\
16,0 \\
5,0 \\
6,0 \\
3,0 \\
3,0 \\
18,0 \\
18,0 \\
20,0 \\
22,0\end{array}$ & $\begin{array}{r}3,5 \\
3,8 \\
11,0 \\
2,7 \\
10,9 \\
4,3 \\
4,2 \\
0,5 \\
1,8 \\
15,3 \\
13,2 \\
8,2 \\
20,0\end{array}$ & $\begin{array}{l}4,7 \\
5,4 \\
4,7 \\
6,6 \\
6,8 \\
5,1 \\
5,4 \\
5,0 \\
5,0 \\
5,4 \\
5,3 \\
5,6 \\
6,6\end{array}$ & $\begin{array}{r}20 \\
58 \\
13 \\
2 \\
99 \\
40 \\
34 \\
21 \\
76 \\
33 \\
93 \\
98 \\
168\end{array}$ & $\begin{array}{l}07 / 88 \\
07 / 88 \\
07 / 88 \\
07 / 88 \\
07 / 88 \\
07 / 88 \\
07 / 88 \\
07 / 88 \\
08 / 88 \\
08 / 88 \\
08 / 88 \\
08 / 88 \\
08 / 88\end{array}$ \\
\hline
\end{tabular}

PROF. - Profundidade do poço

N.E. - Nível estätico

COND. E1. - Condutividade elétrica

ANEXO 02 - CARACTERISTICAS DOS POŞOS ESCAVAdOS DA REGIÃO DE ATTBAIA-SP 




